UNIVERSIDADE DE SÃO PAULO

FACULDADE DE FILOSOFIA, LETRAS E CIÊNCIAS HUMANAS

DEPARTAMENTO DE LETRAS ORIENTAIS

PROGRAMA DE LITERATURA E CULTURA RUSSA

FLÁVIA CRISTINA APARECIDA SILVA

\title{
A CONSTRUÇÃO DA IDENTIDADE EM MACHADO DE ASSIS E TCHEKHOV VERSÃO CORRIGIDA
}




\section{A CONSTRUÇÃO DA IDENTIDADE EM MACHADO DE ASSIS E TCHEKHOV VERSÃO CORRIGIDA}

Flávia Cristina Aparecida Silva

Dissertação apresentada ao Programa de Pós-Graduação em Literatura e Cultura Russa do Departamento de Letras Orientais da Faculdade de Filosofia, Letras e Ciências Humanas da Universidade de São Paulo como requisito para obtenção do título de Mestre em Literatura e Cultura Russa. Pesquisa desenvolvida com apoio da Coordenação de Aperfeiçoamento de Pessoal de Nível Superior (Capes).

Orientador: Prof. Dr. Bruno Barretto Gomide

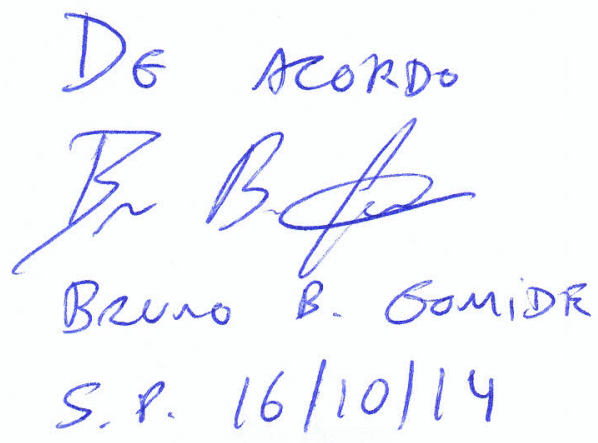

São Paulo

2014 


\author{
UNIVERSIDADE DE SÃO PAULO \\ FACULDADE DE FILOSOFIA, LETRAS E CIÊNCIAS HUMANAS \\ DEPARTAMENTO DE LETRAS ORIENTAIS \\ PROGRAMA DE LITERATURA E CULTURA RUSSA
}

\title{
A CONSTRUÇÃO DA IDENTIDADE EM MACHADO DE ASSIS E TCHEKHOV VERSÃO CORRIGIDA
}

Flávia Cristina Aparecida Silva

Dissertação apresentada ao Programa de Pós-Graduação em Literatura e Cultura Russa do Departamento de Letras Orientais da Faculdade de Filosofia, Letras e Ciências Humanas da Universidade de São Paulo como requisito para obtenção do título de Mestre em Literatura e Cultura Russa. Pesquisa desenvolvida com apoio da Coordenação de Aperfeiçoamento de Pessoal de Nível Superior (Capes).

Orientador: Prof. Dr. Bruno Barretto Gomide 
Autorizo a reprodução e divulgação total ou parcial deste trabalho, por qualquer meio convencional ou eletrônico, para fins de estudo e pesquisa, desde que citada a fonte. 


\section{A CONSTRUÇÃO DA IDENTIDADE EM MACHADO DE ASSIS E TCHEKHOV}

Dissertação de mestrado apresentada ao Programa de Pós-Graduação em Literatura e Cultura Russa do Departamento de Letras Orientais da Faculdade de Filosofia, Letras e Ciências Humanas da Universidade de São Paulo, aprovada pela Banca Examinadora constituída pelos seguintes professores:

Prof. Dr. Bruno Barretto Gomide

Faculdade de Filosofia, Letras e Ciências Humanas Universidade de São Paulo

Orientador

Prof. Dr. Mario Ramos Francisco Jr.

Faculdade de Filosofia, Letras e Ciências Humanas

Universidade de São Paulo

Profa. Dra. Denise Regina de Sales Instituto de Letras da Universidade Federal do Rio Grande do Sul 
Para Raimunda e Erundina 


\section{AGRADECIMENTOS}

Eu gostaria de agradecer em primeiro lugar meu companheiro Rafael Ferreira, por seu apoio incondicional, sem ele, eu não teria conseguido fazer o meu mestrado. É sempre maravilhoso ter alguém que te diga que você é capaz de coisas que você não sabe que é.

Em segundo lugar, agradeço à Coordenação de Aperfeiçoamento de Pessoal de Nível Superior (Capes) pela bolsa concedida, que possibilitou minha total dedicação a esse trabalho nos últimos dois anos.

Agradeço ao meu orientador Bruno Barretto Gomide, um professor e amigo sempre acessível, muito gentil e generoso, fonte de inspiração para a vida. Fui sua aluna em seu primeiro ano na USP e, desde então, minha admiração por ele só cresceu.

Tenho alguns poucos amigos sempre disponíveis, eu os cobri de perguntas ao longo desses anos de mestrado. Um deles é o Rodrigo Nascimento, que eu conheci ainda na graduação. Ele acompanhou todas as etapas deste trabalho, desde quando ainda era apenas um projeto. Obrigada por tudo!

Nem tenho palavras para agradecer a minha querida amiga Priscila Nascimento Marques, sempre presente, disponível a quase qualquer hora do dia. Nem mesmo durante os seus seis meses na Rússia foi menos prestativa. Agradeço a leitura atenta que fez dessa dissertação, com todo o cuidado que lhe é característico.

Agradeço ainda Deise Oliveira, amiga desde os tempos da graduação em russo, nos reencontramos na pós-graduação e retomamos nossa amizade, foi mais um dos presentes que ganhei nesses anos de mestrado.

Gostaria de agradecer também Francisco Araújo, Bianca Paixão, Graziela Schneider, Giuliana Almeida e Mireya Aracena, por serem bons amigos.

Dos amigos, gostaria ainda de agradecer um muito especial, Felipe Freires Carvalho, que chorou e comemorou comigo muitos acontecimentos nesses dez anos de amizade, sei que está sempre na torcida por mim.

Alguns professores deixam profundas marcas em nossa trajetória, tornam-se nossos exemplos, e eu sou profundamente grata a muitos deles, que mudaram a minha vida de alguma maneira, ainda que muitos nem saibam disso. Sempre agradecerei meu professor de 
Biologia da escola, Marcelo de Sousa, que se desdobrava em dez para oferecer suas excelentes aulas e ainda enxergar as aptidões de seus alunos, foi o meu primeiro grande professor e o responsável pela escolha mais importante da minha vida: prestar o vestibular da USP. Agradeço também aos professores: Alcides Villaça, Bruno Barretto Gomide, Elena Vássina, Homero de Freitas Andrade, Annie Gisele Fernandes, Elaine Sartorelli, Julio Groppa Aquino, Betina Bischof e Marcos Martinho dos Santos. Agradeço também ao professor Mário Ramos Francisco Jr. pelas observações úteis que fez no meu exame de Qualificação.

Por último, quero agradecer aos meus familiares. Eu fui criada por duas pessoas maravilhosas, que, infelizmente, morreram muito cedo, minha tia, Raimunda Souza Reis, e minha avó, Erundina Souza Silva. Apesar das limitações de uma vida muito dura, elas sempre acreditaram que tudo era possível. A frase da minha tia, "Não existe nada que você não seja capaz de aprender", ainda ressoa diariamente na minha cabeça.

Agradeço também minha mãe Jorgina, meu sogro Julio e meu cunhado Thiago, que fez uma leitura muito delicada do meu texto de qualificação. Além deles, gostaria de mencionar o meu padrasto Antonio de Oliveira, que se foi tão jovem, mas deixou suas sementes para a minha alegria.

Para encerrar, finalmente, quero agradecer duas das pessoas mais importantes da minha vida, minhas lindas irmãs Camila e Cristiane. Irmãos são os melhores presentes que se pode ganhar da vida, é ter sempre com quem contar, é ter a certeza de que para tudo há uma torcida organizada. Fontes de amor infinito, de felicidade diária e motivo para continuar sempre. Somos um único ser divido em três... Obrigada por tudo. 
A vida só é dada uma vez Anton Tchekhov 
SILVA, Flávia Cristina Aparecida. A construção da identidade em Machado de Assis e Tchekhov. São Paulo, 2014. 128f. Dissertação (Mestrado em Literatura e Cultura Russa) Faculdade de Filosofia, Letras e Ciências Humanas, Universidade de São Paulo.

\section{RESUMO}

Esta dissertação procura entender, através da comparação entre as narrativas "O Alienista" (1882) e a "Enfermaria no 6" (1892); e “O Espelho" (1882) e “Queridinha" (1898), as primeiras de Machado de Assis (1839-1908) e as segundas de Tchekhov (1860-1904), como se formavam as identidades - subjetiva e social - na segunda metade do século XIX, na Rússia e no Brasil. Na primeira comparação, aproximamos dois textos que tratam de um assunto muito discutido naquele período, a loucura. Tentamos entender qual era o lugar do louco na nova configuração dessas duas sociedades e a conformação da loucura em identidade social. Na segunda comparação, sugerimos uma interpretação da teoria apresentada no conto "O Espelho", e analisamos Queridinha, a personagem do conto homônimo de Tchekhov, empregando essa teoria.

Palavras-chave: Machado de Assis; Anton Tchekhov; Literatura Brasileira; Literatura Russa; Identidade. 
SILVA, Flávia Cristina Aparecida. The construction of identity in Machado de Assis and Chekhov. São Paulo, 2014. 128f. Dissertação (Mestrado em Literatura e Cultura Russa) Faculdade de Filosofia, Letras e Ciências Humanas, Universidade de São Paulo.

\begin{abstract}
This dissertation aims to understand, through the comparison between "The Alienist" (1882) and "Ward no. 6" (1892); and "The Mirror" (1882) and "The Darling" (1898), the first ones written by Machado de Assis (1839-1908) and the others written by Chekhov (1860-1904), how subjective and social identities were formed in the second half of the $19^{\text {th }}$ century in Russia and Brazil. In the first comparison we approach the theme of madness, a much discussed topic at the time. We try to understand the place of madmen in the new configuration of both societies and the conformation of madness as social identity. In the second comparison, we suggest an interpretation for the theory presented in "The mirror" and analyze the protagonist of Chekhov's short story "The Darling” though this theory.
\end{abstract}

Keywords: Machado de Assis; Anton Chekhov; Brazilian Literature; Russian Literature; Identity. 
Sumário

INTRODUÇÃO

\begin{tabular}{lr} 
1.1. & Machado de Assis \\
\hline
\end{tabular}

$\begin{array}{lr}\text { 1.2. Tchekhov } & 10\end{array}$

$\begin{array}{lr}\text { 1.3. Estética Realista } & 14\end{array}$

2. AS PUBLICAÇÕES 19

2.1. Papéis Avulsos $r$

2.1.2. Conto ou novela? 23

2.2. A publicação de “Enfermaria no 6" 26

3. IDENTIDADE 29

4. “O ALIENISTA” E “ENFERMARIA № 6”: DUAS NOVELAS SOBRE O MESMO TEMA 33

4.1. Algumas especificidades do texto literário 37

4.2. A vila de Itaguaí e a cidadezinha a 200 verstas da linha do trem 38

4.3. A Enfermaria no 6 e a Casa Verde $\quad 44$

\begin{tabular}{lr} 
4.4. & A loucura \\
\hline
\end{tabular}

4.4.2. A loucura como identidade $\quad 54$

$\begin{array}{lr}\text { 4.4.3. } & \text { Antipsiquiatria }\end{array}$

$\begin{array}{llr}\text { 4.4.4. Psiquiatria hoje } & 68\end{array}$

$\begin{array}{ll}\text { 4.5. } & \text { Bacamarte e Ráguin }\end{array}$

$\begin{array}{ll}\text { 4.5.2. Ráguin e Gromov } & 80\end{array}$

$\begin{array}{llr}\text { 4.6. } & \text { Moderno X Arcaico } & 83\end{array}$

5. JACOBINA E QUERIDINHA: DOIS PROTAGONISTAS 87

5.1. A estrutura dos contos 92

5.2. A formação da identidade: o "eu" e o "outro" 93

5.2.2. Quem é esse outro? 103

5.3. Queridinha através da "nova teoria da alma humana” 104 
5.4. A alma vencedora

5.5. A farda simbólica

5.6. O fantástico e os sonhos

CONSIDERAÇÕES FINAIS

118

REFERÊNCIAS 


\section{Introdução}

Contemporâneo é aquele que mantém fixo o olhar no seu tempo, para nele perceber não as luzes, mas o escuro. ${ }^{l}$

Giorgio Agamben

Abordar o tema das identidades é um desafio, pois toda tentativa de definição transborda por onde quer que tentemos apreendê-la. Tudo o que se diz sobre esse assunto é sempre uma suposição, o que parece claro num momento, deixa de ser no seguinte, isso porque a identidade está sempre em processo de construção e de adaptação, é intangível e ambivalente. Encontrar uma resposta para a pergunta "Quem sou eu?" é uma busca que talvez tenha começado junto com a própria existência humana. No entanto, ela se articula de maneiras diferentes ao longo da história, e está sempre presente de alguma forma em todas as épocas. A busca para compreender a formação das identidades vai além da questão de quem se é neste mundo, mas também envolve uma série de fatores: sociais, econômicos, culturais e políticos.

A chegada ao século XIX trouxe novas perguntas, o indivíduo que surgiu após o Iluminismo, chamado por Hall ${ }^{2}$ de "soberano" descobrirá que está sujeito a novas forças disciplinadoras. É nesse momento que surge o sujeito sociológico, que terá que se adaptar à vida em sociedade, com normas mais coletivas e menos individuais.

Hall trabalha com a ideia que as identidades modernas estão sendo "descentradas", ele parte do princípio que o indivíduo soberano era o próprio centro, e que mesmo durante o período em que teve que se adaptar à sociedade moderna, não perdeu essa soberania. Contudo, agora, encontra-se numa situação em que este centro está se fragmentando. Portanto, segundo essa teoria, os sujeitos contemporâneos enfrentam uma crise de identidade.

Como ocorre a construção das identidades é um processo muito presente nas obras de Anton Tchekhov e Machado de Assis, a esses autores da segunda metade do século XIX importava entender os sujeitos que povoavam o mundo em transformação no qual eles viviam. Como escritores, eles são intérpretes do tempo em que escreviam, conseguindo

\footnotetext{
${ }^{1}$ AGAMBEN, Giorgio. O que é contemporâneo? e outros ensaios. Chapecó/SC: Argos, 2009.

${ }^{2}$ HALL, Stuart. A identidade cultural na pós-modernidade. Trad. Tomaz Tadeu da Silva e Guacira Lopes Louro. Rio de Janeiro: DP\&A, 2011.
} 
perceber não apenas aquilo que estava à vista, como também o que se escondia por trás das convenções sociais.

A escolha do corpus para este trabalho se deve primeiro à espantosa semelhança temática entre "O Alienista" de Machado de Assis e a "Enfermaria no 6" de Tchekhov, que tratam da loucura e sua construção como identidade social, que ganhava, naquele momento, novas interpretações devido aos avanços científicos, que alteraram definitivamente a relação do homem consigo mesmo e com os outros. A loucura, que era relativamente pouco discutida até o século XIX, viria a se tornar um dos grandes temas do século XX.

"O Alienista" é um texto ímpar na obra de Machado de Assis, escrito numa forma, que oscila entre o conto e a novela, que nunca se repetiu durante a sua carreira. A temática da loucura, que já havia aparecido anteriormente em sua obra, descrita a partir de uma visão mais romantizada de mundo, recebe agora um tratamento totalmente inovador.

Apesar dos médicos povoarem a literatura tchekhoviana, os loucos aparecem com menor frequência. No entanto, "Enfermaria $n^{\circ} 6$ " é uma novela escrita por um autor muito ciente da importância de abordar os temas de seu tempo. Ainda que sutil, nesse texto, Tchekhov faz uma denúncia do absurdo que é todo o processo que determina quem é louco.

Como se formam as identidades é o principal assunto do conto "O Espelho", um dos mais famosos de Machado de Assis, que, depois de ter escrito uma obra muito mais próxima da estética romântica, publica um livro como Papéis Avulsos, em que os temas do seu tempo são interpretados por um viés muito particular. O conto trata essencialmente do sujeito que vive no Rio de Janeiro, capital de um país em pleno processo de transformação social e política.

Machado de Assis apresenta algumas hipóteses sobre a formação desse sujeito - as razões que o animam, o que realmente importa para ele e como é atingido pelas questões que estavam em discussão no período. Particularmente relevante para este trabalho é a apresentação do "esboço de uma nova teoria da alma humana ${ }^{3}$ ", que pode ser aplicado a praticamente qualquer um dos personagens do Machado de Assis da segunda fase, ou seja, a partir da publicação de Memórias Póstumas de Brás Cubas, em 1881.

\footnotetext{
${ }^{3}$ Teoria proposta pelo personagem Jacobina no conto "O Espelho".
} 
O conto "Queridinha", que será comparado a "O Espelho" também aborda a formação da identidade, mas, nesse caso, de uma mulher. Enquanto o conto de Machado de Assis pretende ser uma teoria, o de Tchekhov tem um formato mais puramente narrativo, que combina com a despretensão da personagem principal, como veremos.

Todos os textos atendem a uma exigência importante para a compreensão da obra desses dois autores, foram publicados na segunda fase de suas carreiras. A divisão da obra do escritor brasileiro é muito famosa. Machado de Assis (1839-1908) começou a escrever ainda muito cedo, seus primeiros escritos são de 1854, portanto, sob forte influência do Romantismo, que era a escola literária em voga naquele momento entre os intelectuais brasileiros. A partir de 1881, adotará um estilo próprio, de difícil definição, muito próximo do Realismo inglês.

Talvez Tchekhov não possa ser classificado como um caso de twice born, como Machado de Assis, pois o início da sua produção mais madura ocorre ainda em 1886, quando ele tinha apenas 26 anos. A partir desse momento, o tom de suas histórias muda, e surge uma seriedade que não estava presente no primeiro Tchekhov.

Em estudos comparados, a primeira questão que surge é: como pode haver tantas similaridades entre as obras de autores tão distantes espacialmente?

Podemos excluir a possibilidade de que seja uma influência direta, pois, pelo que sabemos, Machado de Assis não leu a obra de Tchekhov, e a possibilidade de Tchekhov ter lido Machado de Assis é remota, já que este demorou muitos anos para ter sua obra conhecida fora do Brasil.

Segundo Jean-Michel Massa, que fez o trabalho exaustivo de levantar e catalogar toda a biblioteca Machado de Assis, incluindo uma pesquisa difícil para saber dos outros cerca de 200 exemplares dessa biblioteca doados no dia seguinte à morte do autor, a literatura russa era representada unicamente por Tolstói ${ }^{4}$. Ele também conhecia obras de Dostoiévski, Turguêniev e Gógol, apesar de não terem sido encontrados exemplares desses autores na biblioteca pessoal de Machado de Assis, ele os citou algumas vezes em suas crônicas. Além disso, segundo Massa, Machado de Assis possuía em sua biblioteca uma antologia de contos de Gógol traduzida para o alemão: Altväterische Leute und andere Erzählungen von Nikolas W.

\footnotetext{
${ }^{4}$ JOBIM, José Luís. (Org.) A biblioteca Machado de Assis. Rio de Janeiro: Academia Brasileira de Letras e Top Books, 2001.
} 
Gogol, Deutsch von Julius Meixner, Collection Spemann, Stuttgart, Verlag von W. Spemann, (s.d).

O ato de comparar obras distintas, de autores tão distantes, como os escolhidos para esta pesquisa, serve para, através da busca por semelhanças e diferenças, compreender melhor os objetos comparados. No caso da comparação que apresentaremos a seguir, podemos dizer que é a situação do homem em finais do século XIX e a posição periférica de Brasil e Rússia que conferem uma estrutura e temas similares aos textos, tornando possível o exercício comparativo. 


\subsection{Machado de Assis}

I was shocked by how charming and amusing it was. I couldn't believe he lived as long ago as he did. You would've thought he wrote it yesterday. It's so modern and so amusing ${ }^{5}$.

Woody Allen

Como escritor número um do país, não deve haver nada sobre Machado de Assis que o seu leitor fiel não saiba. Apesar da famosa circunspecção do autor, é possível que já conheçamos tudo o que havia para ser descoberto sobre ele. No entanto, não podemos deixar de apresentá-lo, principalmente para introduzir alguns assuntos importantes para as interpretações da sua obra que virão a seguir.

Machado de Assis foi objeto de algumas biografias, além das várias pinceladas biográficas presentes na enorme fortuna crítica de sua obra. Para essa pequena apresentação do escritor, utilizamos três biografias: a de Lúcia Miguel-Pereira ${ }^{6}$, que é a mais famosa delas, e é um tanto fantasiosa, porque a autora acaba por completar aquilo que não conseguiu descobrir em sua pesquisa com trechos da obra do autor, o que era uma tendência da época em que foi escrita a biografia, a psicologização da obra, procurando pelo autor em sua produção artística e buscando explicações para a obra em sua vida; a segunda é biografia de Jean Michel Massa ${ }^{7}$, que desmitifica alguns aspectos da vida de Machado de Assis, sobretudo por apresentar o autor ainda quando jovem - o Machadinho -, o que era uma parte obscura de sua vida até então; e a terceira é uma biografia recente, escrita por Daniel Piza ${ }^{8}$.

Machado de Assis trocava muitas cartas com amigos, no entanto, ao contrário de Tchekhov, que abordava constantemente a sua obra em correspondências, o autor carioca falava sempre do seu dia a dia, tocando em questões sobre sua produção literária em raríssimas ocasiões. O que dificulta a construção de uma poética com base em seus comentários.

\footnotetext{
${ }^{5}$ Em uma lista publicada pelo jornal britânico The Guardian, o diretor Woody Allen cita Memórias Póstumas de Brás Cubas como um de seus livros preferidos. In: theguardian.com, Friday 6 May, 2011.

${ }^{6}$ PEREIRA, Lúcia Miguel. Machado de Assis: estudo crítico e biográfico. 5. ed. rev. Rio de Janeiro: J. Olympio, 1953.

${ }^{7}$ MASSA, Jean-Michel. A juventude de Machado de Assis (1839-1870). Rio de Janeiro: Civilização Brasileira INL, 1971.

${ }^{8}$ PIZA, Daniel. Machado de Assis: Um gênio brasileiro. São Paulo: Imprensa Oficial do Estado de São Paulo, 2008.
} 
Joaquim Maria Machado de Assis nasceu em 21 de junho de 1839, no Morro do Livramento, no Rio de Janeiro. Filho de Francisco José de Assis, pardo e neto de escravos, e de Maria Leopoldina Machado, que era açoriana. Aos seis anos, presenciou a morte da única irmã, quatro anos depois sua mãe morreu de tuberculose. Em 1854, o pai casou-se com Maria Inês da Silva. Os pais do autor sabiam ler e escrever e eram assinantes do Almanaque Laemmert, uma publicação da Corte.

O Rio de Janeiro do jovem Machado de Assis é uma cidade em transformação: em 1850, foi decretada a Lei Eusébio de Queirós, que extinguia o tráfico negreiro, mas os escravos ainda contavam 110 mil habitantes entre os 270 do Rio de Janeiro. A urbanização começava a tornar-se uma realidade.

A década de 1850 trouxe muitas modernizações para o Rio de Janeiro. A Corte contava então com quatro teatros, sete livrarias e muitos periódicos. Além disso, só nesse período, 122 mil europeus desembarcaram na cidade, muitos artistas e comerciantes.

Em 1854, Machado de Assis conheceu Francisco de Paula Brito, seu primeiro editor, para quem trabalhava como revisor de provas. A estreia como escritor ocorreu ainda em 1854, escrevera um soneto, que foi publicado pelo jornal Periódico dos Pobres e assinou-o como J. M. M. Assis.

O Teatro Ginásio Dramático foi inaugurado em 1855 e foi o responsável pela divulgação do teatro realista francês, além de promover escritores nacionais, como José de Alencar. O teatro teve papel importantíssimo na carreira de Machado de Assis, que logo se tornou crítico, tradutor de peças e dramaturgo.

O Rio de Janeiro era a Corte de D. Pedro II, que vivia um momento próspero e cheio de festejos, por toda parte havia inaugurações para serem comemoradas: a primeira estrada de ferro, a chegada da iluminação a gás, a reabertura de teatros, entre tantas outras. Machado de Assis admirava o imperador, a quem dedicou alguns poemas.

Ainda muito jovem, por volta de 1860, Machado de Assis rejeitava o Romantismo e o Realismo, o nacionalismo e o colonialismo, e não se declara espiritualista nem materialista. Evitando as fórmulas prontas das ideologias e escolas literárias, acabou por desenvolver um estilo próprio. 
Machado de Assis trabalhou como censor do Conservatório Dramático, de 1862 a 1864, tratava-se de um cargo público, que fiscalizava se havia teor antimonárquico e/ou abolicionista nos textos. Daniel Piza ressalta o fato de que Machado de Assis era liberal, abolicionista e anti-imperalista, já que protestou contra a pretensão da França de conquista do México, mas apoiava a monarquia constitucional brasileira 9 .

O autor jamais viajou para fora do país, quase não deixou o Estado do Rio de Janeiro durante toda a sua vida, apesar de ser muito amigo de Joaquim Nabuco, que viajava muito e logo se mudou para fora do país. Ainda no ano de 1864, publicou seu primeiro livro de poesias, Crisálidas.

Em 1866, Machado de Assis já era conhecido, atuava como poeta, crítico, cronista e dramaturgo. Casou-se com Carolina Augusta Xavier de Novais em 12 de novembro de 1869.

O autor sofreu seu primeiro ataque epilético em 1870, não há registros de ataques anteriores. A doença o incomodaria pelo resto da vida, sobretudo na idade madura, expondo-o aos curiosos, o que atormentava o autor.

Após a Guerra do Paraguai, o exército saíra fortalecido, tinha como ideologia o positivismo francês, principalmente após a chegada do pensador Benjamin Constant ao comando da Escola Militar da Praia Vermelha em 1872, o que, ao lado do declínio do sistema escravocrata, desestabilizava o reinado de D. Pedro II.

Os intelectuais passavam por um momento de transição na agitada década de 1870: Monarquia ou República? Romantismo ou Realismo? Nacionalismo ou Internacionalismo? Essas eram as questões que também perpassavam os textos de Machado de Assis naquele momento.

Ainda em 1870, o autor lançou Contos Fluminenses, a sua primeira coletânea do gênero. O crítico Araripe Jr. reclamou da falta de uma "cor brasileira" na obra, era um momento de exaltação da identidade nacional. Pela primeira vez o tema da loucura apareceria na obra do autor, no conto "Frei Antão".

Nesse primeiro volume de contos, já é possível notar a forma do grande texto machadiano, ainda que seus temas dessa fase estejam muito ligados a uma ideia romântica de mundo, que é dividido entre pessoas boas e más, e as más devem ser e são punidas. Um

\footnotetext{
${ }^{9} \mathrm{PIZA}, 2008$, p. 109.
} 
aspecto importante é que os primeiros romances de Machado de Assis têm como ambiente a Corte, só na segunda fase encontraremos indivíduos mais comuns. Segundo Schwarz, no primeiro Machado de Assis: "De fato, a restrição ideológica era também restrição de assuntos e escolha de conflitos: as questões do individualismo, as novidades da civilização burguesa, e com elas o temário da modernidade, aparecem pouco e têm posição secundária ${ }^{10}$."

Ressurreição, seu primeiro romance, foi publicado em 1872, depois vieram A mão e a luva (1874), Helena (1876) e Iaiá Garcia (1878), romances da primeira fase da carreira do autor, essas obras estão entre o Romantismo e o Realismo. O livro Histórias da meia-noite (1873) e Contos Fluminenes (1870) são coletâneas de contos também da primeira fase do autor.

Daniel Piza chama a atenção para a advertência que Machado escreveu para a segunda edição de Helena em 1905:

Não me culpeis pelo que lhe achardes romanesco. Dos que então fiz, este me era particularmente prezado. Agora mesmo, que há tanto me fui a outras e diferentes páginas, ouço um eco remoto ao reler estas, ecos de mocidade e fé ingênua. É claro que, em nenhum caso, lhes tiraria a feição passada; cada obra pertence ao seu tempo ${ }^{11}$.

Esse trecho é bastante esclarecedor, porque nele o próprio autor acaba por reconhecer uma divisão na sua obra, com uma primeira fase mais romântica, ligada à mocidade, e uma segunda mais realista. Além disso, traz também a declaração do não arrependimento porque esses eram os ecos daquele momento.

Machado de Assis fez, em 1878, uma dura crítica ao romance de Eça de Queirós, $O$ Primo Basílio, principalmente por trazer um Realismo que se aproximava do Naturalismo de Zola. O Naturalismo, sob influência do darwinismo, é uma interpretação social da Teoria da Evolução, em outras palavras, também na sociedade os mais aptos vencerão.

Em 1880, o autor começou a publicar na Revista Brazileira aquele que seria o romance divisor de águas da sua carreira: Memórias Póstumas de Brás Cubas. Publicado no formato de livro em 1881, esse romance também é um marco para a literatura brasileira, que apresentava certa linearidade até o seu aparecimento. A obra era bastante moderna para a época e apresentava um autor em consonância com a literatura mundial, mas, apesar do

\footnotetext{
${ }^{10}$ SCHWARZ, Roberto. Ao vencedor as batatas. São Paulo: Duas Cidades, 2000, p. 85.

${ }^{11}$ PIZA, 2008, p. 170.
} 
sucesso nacional, as qualidades literárias do autor só seriam reconhecidas internacionalmente muitos anos mais tarde.

Ainda em 1881, Machado de Assis começa a trabalhar como cronista da Gazeta de Notícias, um dos maiores jornais naquele momento. O convite fora feito cinco anos antes, mas o autor não pôde aceitar devido a problemas de saúde.

Mais tarde, em 1882, o autor publicaria Papéis Avulsos, o seu primeiro volume de contos da segunda fase, e a terceira coletânea de contos de sua carreira, um marco da segunda fase do autor.

São também da segunda fase da carreira de Machado de Assis os romances: Quincas Borba (1891), Dom Casmurro (1899), Esaú e Jacó (1904) e Memorial de Aires (1908); e as coletâneas de contos: Histórias sem data (1884), Várias Histórias (1896) e Relíquias de Casa Velha (1906).

A narrativa que surge nessa segunda fase é fragmentária, cheia de intervenções à moda de Sterne, com grandes saltos temporais, na qual os fatos são insinuados, não ditos, deixando atônitos aqueles que ansiavam por um final com uma nota moral, tal qual acontecia na primeira fase da sua carreira. Essas obras trazem um final aberto.

Apenas em 1883 Machado de Assis e a esposa mudaram-se para a famosa casa na rua Cosme Velho, nas Laranjeiras.

Era costume da época usar um pseudônimo ao assinar as publicações dos jornais, Machado de Assis teve vários, na Gazeta, por exemplo, foi Lélio por um tempo.

No ano de 1889, Machado de Assis assumiu a Diretoria do Comércio do Ministério da Agricultura, Comércio e Obras Públicas, alcançando com isso um dos cargos mais altos do funcionalismo público e passa a ganhar um salário melhor. Nesse mesmo ano, foi eleito presidente da Academia Brasileira de Letras, instituição de cuja fundação participou um ano antes. Carolina, sua esposa, morreu no dia 20 de outubro de 1904.

Em 29 de setembro de 1908, Machado de Assis morre com 69 anos de idade, reconhecido como o maior autor do país. 


\subsection{Tchekhov}

"I'm crazy about Chekhov. I never knew anyone that wasn't."

Woody Allen

Anton Pavlovitch Tchekhov (Анто́н Па́влович Чехов) nasceu em 29 de janeiro de 1860, na cidade de Taganrog, no sul da Rússia. Seu avô paterno fora servo de gleba. O pai, Pável Egórovitch, era dono de um pequeno armazém, tocava violino e dirigia o coro da igreja. Tchekhov tinha seis irmãos, cinco meninos e uma menina, todos trabalhavam no armazém, e participavam do coro da igreja. O pai era um homem severo, rigoroso e violento. No entanto, todos os filhos estudaram, aprenderam outros idiomas, e tiveram muito contato com arte. Os biógrafos pouco falam sobre a mãe de Tchekhov, apenas que era amorosa.

A infância foi um período difícil, mas de profundo aprendizado. Devido ao trabalho no armazém, Tchekhov conheceu todo tipo de gente, bêbados, trabalhadores em geral, antigos servos. Além disso, o autor estava sempre na igreja, o que enriqueceu seu vocabulário, repleto de linguagem eclesiástica, locuções eslavas e gírias próprias do seminário. Também é nessa época que nasceu a sua admiração pelos professores, figuras constantes em toda a sua obra.

Passava férias com o avô na Aldeia Kniajaia (Ucrânia), longe dos pais, livre das obrigações. Dizia que só lá se sentia em casa e podia ser criança.

Tchekhov começa a ser colaborador de um jornal estudantil com apenas 13 anos. Quando o autor tinha 15 anos, sua família teve que se mudar às pressas de Taganrog por causa das dívidas do pai, foram morar em Moscou. Tchekhov permaneceu em Taganrog para terminar o ginásio. Ficou sozinho dos 15 aos 18 anos, se mantinha dando aulas particulares. Em 1880 escreveu sua primeira peça, Os sem-pai, que ficou conhecida como Platonov (1881).

Em 1881, o tsar Alexandre II, fora vítima de um atentado, que o matou, por causa desse acontecimento, a censura, que já era severa, tornou-se pior, o país passava por um terrível momento em que todos eram suspeitos e delatores.

Após terminar os estudos, Tchekhov muda-se para Moscou, onde estava sua família, e ingressa na Faculdade de Medicina da Universidade de Moscou. 
Começou a escrever pequenos contos para revistas e jornais moscovitas, utilizando o pseudônimo Antocha Tchekhontie. Nesse período, escrevia principalmente para ajudar com as despesas da família. Em 1884, terminou a faculdade de Medicina e tornou-se médico do ziemstvo $^{12}$. Nesse mesmo ano, publica seu primeiro livro Contos de Melpomêne. Em 1886, passa a escrever para o famoso jornal Nóvoie Vrémia (Novo Tempo) de São Petersburgo, do rico editor Alekséi Suvórin, que se tornaria um dos seus maiores amigos.

No verão, viajava para uma casa de campo próxima a Moscou, com a família, onde conheceu camponeses, intelectuais, artistas, nobres e burgueses. Experiência que veio se somar àquelas adquiridas na infância.

Em 25 de janeiro de 1886, Tchekhov recebeu uma carta do influente escritor Grigoróvitch. Nessa carta, o escritor elogia Tchekhov, pede a ele que deixe de usar pseudônimos e o aconselha a recusar os trabalhos com prazos fixos porque são feitos às pressas, o que atrapalha a elaboração literária. Ciente da situação financeira de Tchekhov, Grigoróvitch ressalta que ele precisa fazer isso, mesmo que essa atitude implique passar fome ${ }^{13}$.

Tchekhov responde a Grigoróvitch:

\begin{abstract}
Até agora mantive, em relação ao meu trabalho literário, uma atitude extremamente leviana, negligente e gratuita. Não me lembro de nenhum de meus contos em que eu tenha trabalhado mais do que um dia. "O Caçador", do qual o senhor gostou, escrevi numa casa de banhos! Tenho escrito os meus contos à maneira dos repórteres que tomam notas de incêndios: maquinalmente, meio inconsciente, sem a mínima preocupação nem com o leitor, nem comigo mesmo... Tenho escrito fazendo o possível para não desperdiçar, num conto, as imagens e os quadros que me são caros e que, só Deus sabe a razão, tenho poupado e escondido cuidadosamente $^{14}$.
\end{abstract}

A partir dessa carta, a literatura e a dramaturgia de Tchekhov vão mudando gradualmente, talvez não só por isso, mas também pela maturidade, pela amizade com Suvórin, que o ajudava muito, emprestando livros e dinheiro, quando necessário.

\footnotetext{
${ }^{12}$ Nome dado ao sistema de administração local introduzido em 1864, numa das reformas do czar Alexandre II.

${ }^{13}$ ANGELIDES, Sophia. A. P. Tchekhov: Cartas para uma Poética. São Paulo: EDUSP, 1995, p. 47.

${ }^{14}$ TCHEKHOV apud ANGELIDES, 1995, p. 48.
} 
Em 1887, descobre que está com tuberculose, faz uma viagem à Ucrânia e ao Cáucaso, escreve sua primeira novela, A estepe, e uma peça de grande sucesso, Ivanov.

Apesar do seu afastamento da política, três episódios marcariam sua história, o primeiro quando apoiou Émile Zola, que fora acusado de afrontar o poder constituído na França ao defender o capitão Dreyfus ${ }^{15}$. O segundo acontecimento ocorreu quando Tchekhov e o escritor Korolenko renunciaram às suas cadeiras na Academia de Ciências, na seção de Beletrística, em apoio a Górki, que teve sua eleição anulada pelo próprio tsar, que o acusava de crime político. O terceiro episódio foi sua viagem à Ilha de Sacalina, no extremo leste da Sibéria, local de presídios e trabalhos forçados. Lá permaneceu por seis meses, no ano de 1889, mesmo ano em que seu irmão Nikolai falece, o que deixou Tchekhov extremamente abalado.

Os narodniks, antecessores da revolução, sonhavam com uma saída para todos os problemas, que seria o regresso ao passado, à agricultura, à vida no campo. Tchekhov, que vivia no campo, tinha uma opinião bem diferente da elite intelectual das cidades, sabia das dificuldades dos camponeses que eram ignorantes, alcoólatras, agressivos, entre outras coisas. Essa visão fica clara nas novelas Minha Vida (Моя жизнь) е Os Mијіquеs (Мужики). O que o distancia dos ideais de autores como Tolstói, que idealizava a vida campestre.

Dal-Ri Peres ${ }^{16}$ chama a atenção para o fato de que há muitos críticos, inclusive a biógrafa francesa Sophie Laffitte, que apontam para uma tendência idealista na obra de Tchekhov, havendo então um conflito entre o "idealismo" e o "materialismo" em sua obra. Peres, no entanto, considera esse um conflito que não deve ser atribuído ao autor, mas aos seus personagens, dos quais Tchekhov faz uma representação artística realista. Essa confusão entre o ideário do autor e dos personagens era um lugar-comum nas biografias da época.

Os biógrafos de Tchekhov, como Sophie Laffitte, contaram com um bom material para seus estudos, as cartas deixadas pelo autor. Sua correspondência é imensa, e torna possível a

${ }^{15}$ O Caso Dreyfus ocorreu na França entres os anos de 1894 e 1914. Alfred Dreyfus, membro do exército francês de origem judaica, foi acusado de ter escrito uma carta com informações secretas ao exército da Alemanha. O documento, que apresentava anotações militares do governo, foi roubado da embaixada da Alemanha e disseram haver a grafia de Dreyfus no documento. Ele foi condenado como traidor no ano de 1894 e deportado para a Ilha do Diabo, localizada na Guiana Francesa. Após dois anos, foi descoberto que o autor da carta era Esterhazy, um oficial do Estado-Maior. A partir desse momento, a França divide-se em grupos pró e contra a revisão do caso. O escritor Émile Zola escreveu uma carta em que denunciava o julgamento errôneo.

16 PERES, Paulo Dal-Ri. O Discurso Psquiátrico e anti-psquiátrico de Tchekhov em sua manifestação literária. Tese de doutoramento apresentada ao Programa de Pós-graduação em Literatura e Cultura Russa do Departamento de Letras Orientais da Faculdade de Filosofia, Letras e Ciências Humanas da Universidade de São Paulo, 1984. 
construção de quem era Tchekhov também pelas respostas daqueles que o conheciam. Laffitte dá grande destaque em sua biografia para o fato de que Tchekhov não coincidia com a imagem que as pessoas tinham dele. Era, por exemplo, capaz de mandar construir uma escola e sustentá-la por toda a vida, sem que jamais alguém soubesse que ele o tinha feito, e, quando era questionado a respeito, mudava de assunto. No geral, as pessoas o descreviam como “seco”, pouco amigável.

Tchekhov é um contista que trabalha a concisão até o máximo possível, com economia de elementos narrativos, tornando suas composições curtíssimas, e é também um dos fundadores do teatro moderno. No teatro, é famoso por desenvolver uma dramaturgia com o quase esvaziamento das ações dramáticas e o atraso ou inexistência da ação.

Os assuntos de suas obras são o povo, a vida cotidiana, o drama humano para sobreviver. Na obra de Tchekhov, estão desde os nobres, passando pela classe média, até o mais pobre dos cidadãos. Sua obra, realista, é um rico panorama da Rússia das duas últimas décadas do século XIX e início do século XX. Seus ideais eram a liberdade, a ética, o progresso, o belo, o trabalho honesto, a ciência, a dedicação aos desfavorecidos, crianças e mulheres. Critica o estilo de vida burguês nas pequenas e médias cidades russas.

Tchekhov muda-se para Miélikhovo, ao sul de Moscou, em 1892, e lá permanece até 1899. Costumava pescar da janela de sua casa. Durante os sete anos em que vive na região, colaborou com a construção de hospitais e escolas, e trabalha, sem remuneração, como médico. Durante este período viveu em contato com os mujiques, conhecendo ainda mais profundamente a miséria.

O pai morre em setembro de 1898 e ele adquire uma casa em Ialta, na Crimeia. Mudase para lá no ano seguinte devido aos seus problemas de saúde, a proximidade do mar fazia-o melhorar. Lá, ele escreveu um dos seus contos mais famosos, "A dama do cachorrinho" (Дама с собачкой), em 1899. Sente-se bastante entediado, em suas cartas, sempre fala da vontade de estar em Moscou.

A Gaivota (Чaйкa), uma das suas peças mais famosas, foi encenada pela primeira vez em 1896, mas não obteve sucesso. Dois anos depois, Konstantin Stanislávski e Vladímir Nemiróvitch-Dântchenko, tinham acabado de fundar o Teatro de Arte de Moscou e reencenaram a peça, com grande sucesso, o símbolo do teatro passou a ser uma gaivota. 
Tchekhov ainda escreveria “Tio Vânia” (Дядя Ваня - 1897), “As três irmãs” (Три cecmpbl 1901) e "O jardim das cerejeiras" (Вишневый сад - 1903).

Foi na companhia de Stanislávski que Tchekhov conheceu sua esposa, a atriz Olga Knipper, com quem teve um difícil relacionamento, principalmente devido à grande distância que os separava. Tchekhov vivia em Ialta, ao lado do Mar Negro, por recomendação médica, e Olga vivia em Moscou, onde trabalhava.

Sempre foi uma frustração para Tchekhov não ter escrito um romance, ele arriscou escrever dois: Três anos e Minha vida. Tentou durante muito tempo escrever histórias mais longas, mas tinha facilidade para as narrativas curtas. Três anos acabou sendo uma novela publicada em 1895 na revista Russkaia Mysl. Em 1895, Alekséi Tíkhonov pediu a Tchekhov uma colaboração para a revista Niva, da qual era então o redator-chefe, e Minha Vida, que seria um romance, também acabou tornando-se uma novela, que foi enviada por Tchekhov com bastante atraso para a revista.

Após "No fundo do barranco", de 1900, Tchekhov só escreveu mais dois contos. As narrativas desse período são em número menor, mas tendem a ser mais longas. O humor, frequente nos seus textos da década de 1880, quase desaparece.

Tchekhov morreu no dia $1^{\text {o }}$ de julho de 1904 , em um sanatório na cidade de Badenweiler, na Alemanha, um ano antes da primeira revolução russa, seu corpo veio para Moscou num vagão frigorífico que trazia ostras ${ }^{17}$.

\subsection{Estética Realista}

O Realismo, como movimento literário, surgiu na segunda metade do século XIX em oposição ao Ultraromantismo, fase mais exacerbada do Romantismo. A publicação do romance Madame Bovary de Gustave Flaubert, em 1857, é considerada um dos marcos para a história da estética realista.

O mundo passava por uma série de cisões importantes naquele momento, o que se refletia nas artes em geral. O clero e a aristocracia estavam, aos poucos, deixando de ser os responsáveis pela orientação da vida política nas grandes cidades. Os indivíduos que

\footnotetext{
${ }^{17}$ Esta breve biografia foi escrita com base nos livros: RAYFIELD, Donald. Anton Chekhov - A Life. London: Faber Finds, 2013; LAFFITTE, Sophie. Tchekhov. (trad. de Hélio Pólvora). Rio de Janeiro: José Olympio, 1993; e no livro de Sophia Angelides, já citado.
} 
compunham a pequena burguesia, que hoje chamamos de classe média, passaram a ocupar um lugar de destaque. Burguesia e proletariado uniram-se à nobreza, para lutar por seus direitos, mas se separaram mais tarde, porque os proletários começaram a notar características que apontavam a burguesia como a nova vilã da história.

Nesse cenário, surge então a obra de Karl Marx e Friedrich Engels, o Manifesto Comunista, de 1848, que trata da tensão entre burguesia e proletariado, reconhecendo a burguesia como a nova classe opressora. O livro foi escrito durante as Revoluções de 1848, que ficaram conhecidas como Primavera dos Povos, que reivindicavam reformas sociais, diminuição da jornada diária de trabalho de doze para dez horas e o voto universal.

O historiador Arnold Hauser define assim a importância que o dinheiro passou a ter principalmente na segunda metade do século XIX: “o dinheiro é a força que domina toda a vida pública e privada e [...] todos os direitos passam a se exprimir através dele. Tudo, para ser compreendido, tem de se reduzir a um denominador comum: o dinheiro ${ }^{18 \%}$. Esse trecho resume bem como passaram a ser as relações a partir da consolidação do capitalismo industrial.

O cientificismo tomava o lugar do subjetivismo do momento anterior, agora todos os fenômenos da natureza, inclusive a existência, tinham uma explicação científica. Os jornais passaram a ser essenciais para que os cidadãos das grandes cidades do mundo se mantivessem informados de todos os acontecimentos.

Ao mesmo tempo em que as descobertas no campo das ciências exatas e biológicas ocorriam, surgiram novas teorias filosóficas, de caráter marcadamente materialista, o mundo era interpretado a partir da observação. A principal doutrina do período é o Positivismo, que baseia suas teorias em fatos e na experiência concreta.

O materialismo, o determinismo e o objetivismo acabaram por compor o tom da escola literária surgida naquele momento. Os escritores da segunda metade do século XIX demonstram um compromisso maior com o sua época, por isso os personagens passam a ser cada vez mais parecidos com pessoas reais. Na esteira do determinismo, os personagens aparecem fortemente vinculados ao ambiente em que vivem.

\footnotetext{
${ }^{18}$ HAUSER, A. História social da arte e da cultura. São Paulo: Martins Fontes, 2003, p. 887.
} 
Flaubert, Maupassant, Zola, Anatole, entre outros, são os ícones da primeira geração de ficção realista, muito ligados à objetividade; Comte, Taine, Spencer, Darwin, Haeckel e Renan são as principais influências teóricas.

(No Brasil) a partir da extinção do tráfico (negreiro), em 1850, acelerara-se a decadência da economia açucareira; o deslocar-se do eixo de prestígio para o Sul (graças ao crescimento das lavouras e do comércio cafeeiro) e os anseios das classes médias urbanas compunham um quadro novo para a nação, propício ao fermento de ideias liberais, abolicionistas e republicanas ${ }^{19}$.

Esses serão os assuntos abordados pelos intelectuais nacionais, junte-se a esses as teorias do evolucionismo de Darwin e o Positivismo de Comte.

Machado de Assis, ainda muito jovem, escreveria em uma de suas críticas teatrais: "Não subscrevo, em sua totalidade, as máximas da escola realista, nem aceito, em toda a sua plenitude, a escola das abstrações românticas; admito e aplaudo o drama como forma absoluta de teatro, mas nem por isso condeno as cenas admiráveis de $\operatorname{Racine}^{20}$."

No comentário acima, o escritor demonstra maturidade estética para se posicionar em relação às duas escolas literárias, o Romantismo do qual foi adepto o primeiro Machado de Assis, e o Realismo, que entusiasmava os escritores da segunda metade do século XIX. Não rejeitava nenhum dos dois movimentos, mas também não se dizia totalmente adepto a nenhum. Ao contrário da maioria dos escritores ligados ao Realismo brasileiro, que seguiam os exemplos do Realismo francês, Machado de Assis tinha como mestres escritores de língua inglesa: Shakespeare, Laurence Sterne e Jonathan Swift.

O crítico Eugène-Melchior de Vogüé, um dos principais responsáveis por difundir a literatura russa no Ocidente, publicou o livro O Romance Russo (reunião de textos publicados na Revue des Deux Mondes entre 1883-1886), no qual exalta as qualidades da grande literatura russa de Púchkin, Gógol, Turguêniev, Dostoiévski e Tolstói. Em sua opinião, a literatura russa representava uma opção redentora ao Naturalismo de Zola e ao mecanicismo e cientificismo positivista do Realismo francês. Na opinião Vogüé, os russos defendem as causas do Realismo com argumentos novos.

\footnotetext{
${ }^{19} \mathrm{BOSI}$, Alfredo. História concisa da literatura brasileira. São Paulo: Pensamento-Cultrix, 1994, p. 163.

${ }^{20}$ MACHADO apud PIZA, 2008, pp. 87-9.
} 
Anos mais tarde, Melchior de Vogüé escreveu um ensaio para a mesma Revue des Deux Mondes sobre Tchekhov e Górki ${ }^{21}$. Nesse artigo, chama Tchekhov de amargo e pessimista, e diz que sua obra pouco representa a sociedade russa. O crítico classificou a literatura de Tchekhov como uma espécie de naturalismo "médico". O que espalhou para fora da Rússia a ideia de que Tchekhov era pouco russo. Importante dizer que, ainda que Vogüé tenha feito observações negativas a respeito da obra de Tchekhov, seu papel é decisivo para a divulgação da literatura russa no Ocidente, inclusive no Brasil ${ }^{22}$.

Vogüé destacava na literatura russa um exotismo, uma "alma" que só os escritores russos possuíam, que fazem a literatura russa parecer uma espécie de religião, que, para ele, era fortemente representada pela literatura de Dostoiévski e Tolstói. A principal crítica era que faltava a Tchekhov e Górki a força moral que Vogüé via no Realismo anterior a esses dois escritores. Além disso, Nascimento ${ }^{23}$ chama a atenção para o fato de que o gênero conto talvez também não atendesse às demandas do crítico, por sua natureza curta, que dificultava o desenvolvimento temático.

A literatura de Tchekhov surge após o fim da idade de ouro do romance realista, que, segundo Billington, ocorreu no final da década de 1880. Turguêniev escreveu sua última novela no final dos anos setenta. Dostoiévski e Mússorgski morreram em $1881^{24}$.

Tchekhov sofre com a crítica da época, que não fazia ligação de sua literatura com a grande literatura russa, que tem como maiores representantes, no fim do século XIX e início do XX, Dostoiévski e Tolstói. Tchekhov era acusado de ser pouco russo, tanto na Rússia quanto fora dela. Na Rússia, os escritores e os próprios leitores não viam o engajamento "necessário" em sua obra.

Boris Eikhenbaum escreve sobre a estranheza que Tchekhov causava:

Depois de Turguêniev, Dostoiévski, Tolstói, Saltikóv-Chtchendrin e Gleb Uspênski, os contos de Tchekhov eram vistos por muitos como a expressão de apatia e indiferença social. Começaram a falar do caráter 'casual' dos temas tchekhovianos, da colocação indiferente dos

\footnotetext{
${ }^{21}$ VOGÜÉ, E. M. “Anton Tchekhof”. Revue des Deux Mondes. Jan-Fev 1902, p. 201-216.

${ }^{22}$ Para saber mais a respeito, consultar GOMIDE, Bruno Barretto. Da Estepe à Caatinga: O Romance Russo no Brasil (1887-1936). São Paulo: Edusp, 2012.

23 NASCIMENTO, Rodrigo Alves do. Tchékhov no Brasil: a construção de uma atualidade. Dissertação de mestrado apresentada ao Programa de Pós-graduação em Literatura e Cultura Russa do Departamento de Letras Orientais da Faculdade de Filosofia, Letras e Ciências Humanas da Universidade de São Paulo, 2013.

${ }^{24}$ BILLINGTON, James H. El icono y el hacha. Madrid: Siglo XXI de España Editores, 2011, p. 605.
} 
fatos e acontecimentos, da ausência de uma visão de mundo. Causava surpresa o fato de Tchekhov só relatar ninharias de toda espécie e não explicar nada ${ }^{25}$.

Curiosamente, Machado de Assis também era considerado pouco brasileiro principalmente por não tratar em sua obra de questões ligadas à formação da pátria, como os temas indígenas, a natureza, tão em voga na sua época. A questão se complicava ainda mais porque, quando Machado de Assis começou a aparecer no meio literário, havia uma espécie de movimento nacionalista na literatura brasileira, escritores como Bernardo Guimarães, José de Alencar, Joaquim Manuel de Macedo, Sílvio Dinarte, Franklin Távora, entre outros, queriam uma literatura mais independente, com traços mais locais, menos europeus.

\footnotetext{
${ }^{25}$ ANGELIDES apud EIKHENBAUM, 1995.
} 


\section{As publicações}

\subsection{Papéis Avulsos}

O livro Papéis Avulsos (1882) é a terceira coletânea de contos de Machado de Assis. Pertence a sua segunda fase como escritor, ou seja, após 1880, e representa para Machado de Assis contista o mesmo que Memórias Póstumas de Brás Cubas representa para o romancista. Nesse livro, identificamos as mesmas características dos seus grandes romances: domínio de elementos narrativos, como o monólogo interior; desenvolvimento de temas ainda não trabalhados por autores brasileiros, como a condição do agregado e dos indivíduos que compõem a classe dominante brasileira.

"O Alienista" abre o livro, que, além dessa narrativa, contém onze contos ("Teoria do medalhão", "A chinela turca", "Na arca", "D. Benedita", "O segredo do Bonzo", "O anel de Polícrates", "O empréstimo", "A sereníssima República”, "O Espelho”, "Uma visita de Alcebíades" e "Verba Testamentária"), a maior parte deles foi publicada antes na Gazeta de Notícias.

O título do livro é ambíguo porque parece falar de papéis recolhidos e que vieram, por acaso, parar onde estão. $\mathrm{O}$ autor explica então a escolha do título na advertência feita na abertura do livro:

\footnotetext{
Este título de Papéis Avulsos parece negar ao livro uma certa unidade; faz crer que o autor coligiu vários escritos de ordem diversa para o fim de os não perder. A verdade é essa, sem ser bem essa. Avulsos são eles, mas não viera, para aqui como passageiros, que acertam de entrar na mesma hospedaria. São pessoas de uma só família, que a obrigação do pai fez sentar à mesma mesa ${ }^{26}$.
}

No entanto, essa explicação abre ao menos duas possibilidades de leitura: não desmancha a ideia de que os papéis são avulsos mesmo, foram recolhidos aqui e ali, e, por isso, podem ser interpretados de diferentes maneiras, mas deixa claro que há um motivo para

\footnotetext{
${ }^{26}$ ASSIS, Machado. Papéis Avulsos. São Paulo: Penguin \& Companhia das Letras, 2011, p. 37.
} 
que todos estejam no mesmo volume - há ao menos uma chave de leitura pela qual todos os componentes do livro se ligam $^{27}$.

Segundo o autor, todas as histórias do livro foram escritas e publicadas em periódicos já com a finalidade de formarem um único volume, com exceção de "Chinela turca". Papéis Avulsos foi quase todo escrito e publicado em jornais nos anos de 1881 e 1882, o que reforça a unidade do livro.

Daniela Magalhães da Silveira aponta como principal eixo temático da obra o cientificismo, que era moda na época.

\begin{abstract}
Em alguns desses contos, a discussão de pontos que interessavam aos cientistas da época serviu para questionar seus contemporâneos. Em outras histórias, isso não passou de subterfúgio para discussão de problemas mais específicos, como questões em torno do romantismo e da veleidade de literatos e sobre a situação política do país ${ }^{28}$.
\end{abstract}

A primeira história da coletânea é "O Alienista", uma narrativa que apresenta praticamente todos os grandes temas que serão abordados ao longo do livro: o cientificismo, o papel da Medicina naquele momento, o lugar do sujeito naquele mundo em transformação, o papel da mulher, a finalidade do casamento e o funcionamento das relações de poder naquela sociedade. "O Alienista" tem 13 capítulos, todos com nome, na edição original ocupou 90 páginas das 300 de Papéis Avulsos ${ }^{29}$, e em suas edições mais recentes ocupa 60 páginas ou um pouco mais.

Não era a primeira vez que o tema da loucura aparecia na literatura brasileira, os contos de Noite na taverna (1855), de Álvares de Azevedo, e também O seminarista (1872), de Bernardo Guimarães tratam do assunto. Além disso, Machado de Assis já abordara o tema no conto "Frei Simão", da coletânea Contos Fluminenses (1870). No entanto, "O Alienista" é a primeira obra a abordar a implantação de um hospício e questionar o papel da psiquiatria na sociedade brasileira.

Machado de Assis vinha percebendo os abusos praticados tendo como base o discurso científico já há algum tempo, o que é possível notar em suas publicações nos periódicos desde 1880. No período em que escrevia os contos de Papéis Avulsos, os intelectuais da época

\footnotetext{
${ }^{27}$ SILVEIRA, Daniela Magalhães da. Fábrica de Contos: Ciência e Literatura em Machado de Assis. Campinas: Ed. Unicamp, 2010. A pesquisadora faz, nesse livro, um trabalho detalhado sobre a edição de Papéis Avulsos e Histórias Sem Data.

${ }^{28}$ Ibidem p. 96

${ }^{29}$ Ibidem p. 118
} 
estavam preocupados em definir a "identidade" do povo brasileiro e cabia também à literatura, e às artes em geral, ajudar a delinear esse perfil. Além disso, os discursos científicos eram manipulados pelas autoridades com o fim de validarem políticas públicas inaceitáveis, como a expulsão de moradores pobres da Corte e a destruição dos cortiços. Os moradores que restavam, a elite fluminense, eram então a feição do Brasil ${ }^{30}$.

A partir da década de 1870, as correntes científicas começaram a ser disseminadas no país, incluindo o darwinismo, dando início a uma onda de cientificismo, que estaria presente nas conferências, nos jornais, nas rodas de intelectuais, nas associações etc. Apesar do exagero, o discurso científico ajudou a evidenciar o quanto era inadmissível a escravidão e também auxiliou na formulação de algumas leis. Papéis Avulsos pode ser lido como uma espécie de posicionamento de Machado de Assis diante do cientificismo da época ${ }^{31}$.

A moda do discurso cientificista justifica a presença de três médicos em Papéis Avulsos - Diogo Meirelles de "O segredo do bonzo", o cunhado de Nicolau em "Verba testamentária" e Simão Bacamarte de "O Alienista". Além disso, há vários personagens que adotam o tom de autoridade científica para comunicar seus "achismos", caso de Jacobina de “O Espelho" e do pai de Janjão em "Teoria do medalhão".

Também é com base em discursos científicos que uma série de remédios milagrosos começaram a circular no Rio de Janeiro. Fórmulas que seriam capazes de curar os indivíduos de todos os males. Machado de Assis fará ironia com as novidades dos droguistas (farmacêuticos) muitas vezes. O episódio mais famoso de sua literatura envolvendo um remédio talvez seja o emplasto de Brás Cubas. Simão Bacamarte, de "O Alienista”, também anseia pela cura de todos os tormentos mentais da humanidade.

O biógrafo Daniel Piza lembra que Machado de Assis, que sofria de má digestão, fez piada, em uma de suas crônicas, propondo a invenção de uma droga que seria excelente: a Trintimila ou Centimila, que ofereceria a quem as tomasse um meio de pensar sem cérebro. Assim como a propaganda de um vinho estomacal da época, que dizia fazer o trabalho do estômago.

Silveira destaca o fato de que Papéis Avulsos era um exercício do autor de tornar pública a arbitrariedade com que as descobertas científicas e doutrinas eram divulgadas, já

\footnotetext{
${ }^{30}$ Ibidem p. 128

${ }^{31}$ PIZA, 2008.
} 
que não acrescentavam nada à realidade social. Além disso, a pesquisadora ressalta que os primeiros críticos do livro já fizeram a ligação entre os personagens e algumas figuras contemporâneas à obra.

As marcações de tempo são muito precisas na obra machadiana, há sempre exatamente o ano em que o fato narrado transcorreu. As exceções são "O empréstimo", “O Espelho" e "O Alienista", mas é possível adivinhar, através de pistas que aparecem na história, uma data possível. Jacobina, protagonista de "O Espelho", entrou para a Guarda Nacional, para ser alferes, portanto a história se passa no período da Regência (1831-1840). Já em "O Alienista" a definição é um pouco mais problemática, isso porque o autor apagou propositalmente as marcas temporais da novela quando foi adaptá-la para a coletânea. John Gledson diz que a história se passa em algum momento no período colonial brasileiro e após a queda da Bastilha $^{32}$.

Umas das formas que mais aparecem no livro é o diálogo, “Teoria do medalhão”, por exemplo, é um conto que consiste apenas em uma conversa entre pai e filho. Uma outra forma de conversa aparece em Papéis Avulsos, a conferência, em que só um fala, aquele que tem a autoridade científica, enquanto os outros escutam, que é o caso de “O Espelho", em que Jacobina assume ares de grande entendedor da alma humana para fazer com que seus amigos ouçam a sua história sem discordarem; há também a conferência do cônego Vargas em "A sereníssima República”.

Papéis Avulsos, assim como Memórias Póstumas de Brás Cubas, foi escrito num clima de incertezas, havia a questão do regime escravocrata, que se tornava cada vez mais insustentável diante dos outros países; havia também dúvidas quanto ao regime - Monarquia ou República -; além da moda cientificista, que tinha uma explicação para todas as coisas, ainda que a maioria da população não entendesse, visto que o índice de analfabetismo era altíssimo.

O livro foi bem recebido pela crítica, Daniel Piza destaca a leitura de Araripe Jr., que saiu na Gazeta da Tarde de 28 de outubro de 1882:

De quanta utilidade não seria pararmos, refletirmos nas verdades que se encerram naquela notável Teoria do Medalhão [sic], em que o filósofo poeta estampa um dos característicos

\footnotetext{
${ }^{32}$ GLEDSON, John. "O machete e o violoncelo" In Por um novo Machado de Assis. São Paulo: Companhia das Letras, 2006, pp. 49-50.
} 
fatores da nossa decadência? Acaso não está na consciência de todos que a nossa máquina governamental move-se por um impulso há longos anos adquirido? Que os homens que entram na composição dos gabinetes são peças que substituem outras já gastas e quando penetram na engrenagem não aparecem como elemento novo, senão [...] para a manutenção do ritmo costumeiro? $?^{33}$

\subsubsection{Conto ou novela?}

Machado de Assis, já prevendo a celeuma em torno da indefinição do gênero de "O Alienista", resolveu adiantar-se e explicar-se em sua advertência, no entanto, ele não desfaz a dúvida:

“Quanto ao gênero deles, não sei que diga que não seja inútil. O livro está nas mãos do leitor. Direi somente que se há aqui páginas que parecem meros contos, e outras que não são, defendo-me das segundas com dizer que os leitores das outras podem achar nelas algum interesse, e das primeiras defendo-me com S. João e Diderot. O evangelista, descrevendo a famosa besta apocalíptica, acrescentava (XVII, 9): 'E aqui há sentido, que tem sabedoria'. Menos a sabedoria, cubro-me com aquela palavra. Quanto a Diderot, ninguém ignora que ele não só escrevia contos, e alguns deliciosos, mas também aconselhava a um amigo que os escrevesse também. E eis a razão do enciclopedista: é que quando se faz um conto, o espírito fica alegre, o tempo escoa-se, e o conto da vida acaba, sem a gente dar por isso ${ }^{34}$."

O autor não define o que é conto e o que não é, apenas eximi-se da culpa dizendo que todos os escritos que lá estão enfeixados têm motivo para estar ali. Além disso, lembra que definir o gênero não tem serventia nenhuma.

A seguir, serão apresentadas algumas famosas definições do que é novela, com o intuito apenas de mostrar o quanto a questão do gênero é de difícil esclarecimento. Não há pretensão de esclarecer definitivamente se "O Alienista” é ou não uma novela.

Para o poeta e crítico literário A. W. Schlegel ${ }^{35}$, o que há de particular na novela que a diferencia do conto e do romance é a sua ênfase na ação, principalmente no momento de crise. Trata-se de uma reviravolta (wendepunkt) no destino das personagens. Segundo essa definição, a novela exige então uma mudança no destino dos personagens e um fato

\footnotetext{
${ }^{33}$ PIZA, 2008, p. 226.

${ }^{34}$ ASSIS, Machado de. Papéis Avulsos. São Paulo: Penguin \& Companhia das Letras, 2011, p. 37.

${ }^{35}$ SCHLEGEL apud GROJNOWSKI, Daniel. Lire la nouvelle. Paris: Nathan, 2000, p. 23.
} 
inesperado costuma ser o responsável por isso. Schlegel chamou essa definição de "teoria do falcão" em referência a um dos episódios ${ }^{36}$ do Decamerão, de Giovanni Bocaccio.

"O Alienista" encaixa-se na teoria de Schlegel, pois Simão Bacamarte sofrerá uma grande mudança em sua vida, de médico, tratado quase como uma divindade, acaba preso em seu próprio hospício, fazendo a passagem de alienista para alienado. O mesmo ocorre com o protagonista da "Enfermaria n ${ }^{\circ} 6$ ".

Para o teórico do Formalismo Russo Boris Eikhenbaum ${ }^{37}$, as narrativas dividem-se em complexas (crônicas extensas, relatos de viagem e romances) e simples (anedota, o conto e a novela). Eikhenbaum vê então uma clara oposição entre o romance, que seria proveniente do relato de viagem, e a novela, que tem sua origem no conto, na anedota, ou seja, ele não aponta uma grande diferença entre conto e novela.

O teórico francês Yves Stalloni ${ }^{38}$ apresenta uma definição bastante didática do que é novela: é uma narrativa breve; apresenta um único acontecimento, em torno do qual se organiza a narração; apresenta uma organização estrutural simples; trata de apenas um fragmento da vida do personagem; é contada por um único narrador, que conduz o leitor do começo ao fim: "Mesmo se, às vezes, a função da narrativa é delegada pelo autor que se viu, ele mesmo, contando a história, que faz sua re-transcrição através de uma carta encontrada ou recebida, que relata o conteúdo de um sonho ou a matéria de uma crônica ${ }^{39}$ ". No caso de "O Alienista", trata-se do conjunto de crônicas de uma cidade.

Poucas personagens compõem a novela, apenas aquelas importantes para a história. A novela, como toda narrativa breve, resume os fatos narrados, os preparativos que antecedem o acontecimento principal são eliminados, começando já in media res, atingindo o clímax e desenlace mais rapidamente.

As categorias de tempo e espaço devem ser bem trabalhadas, de maneira que sejam exatas, o que causa um "efeito de verdade", a novela apresenta um mundo que deve se parecer com o real. "Essa verdade é percebida tanto no valor de testemunho quanto na revelação psicológica que permite à personagem, projetada na nudez de sua experiência, ir ao encontro

\footnotetext{
${ }^{36}$ Nesse episódio, o protagonista oferece um falcão para sua amada comer, para que ela se cure de uma doença, no entanto, este é o único bem que ele possuía. Por causa desse gesto a moça apaixona-se por ele.

${ }^{37}$ EIKHENBAUM, Boris. In TOLEDO, Dionísio de Oliveira (org.). Teoria da literatura: formalistas russos. Porto Alegre: Ed. Globo, 1971.

${ }^{38}$ STALLONI, Yves. Os gêneros literários. Trad. Flávia Nascimento. Rio de Janeiro: Difel, 2001.

39 Idem, p. 115.
} 
de uma verdade subjetiva, que é a de seu próprio eu (Flaubert, Maupassant, Tchekhov, Pirandello, Arland.... $)^{40}$."

Stalloni ressalta ainda que os critérios de identificação de uma novela são incertos, fazendo do gênero fugidio, sendo comumente confundido com o conto.

Da mesma maneira que as definições de gênero têm um aspecto fugidio, "O Alienista" também parece transbordar o gênero, não se encaixa perfeitamente em todas as categorias que delimitam o que é novela ou conto.

Uma outra leitura possível é que, quando o autor diz, que "há páginas que são meros contos e outras que não são", ele esteja se referindo ao fato de que "O Alienista" é mais do que apenas um conto ou uma novela, ele é uma mistura de gêneros.

"O Alienista" apresenta estrutura de ao menos três gêneros diferentes: a novela, o conto e a crônica. A extensão, a narração convergindo para um único ponto e a construção dos personagens parecem afastar o texto da estrutura do conto e aproximá-lo mais da novela. Muitas vezes o narrador nos lembrará que ele está construindo aquela história juntando pequenas crônicas da cidade de Itaguaí. Essa reunião de muitas pequenas histórias que convergem para um único acontecimento e personagem são elementos próprios da estrutura da novela.

Além disso, parece plausível que, no texto de abertura do livro, no qual está contido todos os temas que serão tratados nos outros "papéis", o autor fizesse uma "brincadeira" com o leitor, construindo uma narrativa, que ora se assemelha ao conto, ora à novela, confundido-o propositalmente. Isso se enquadraria perfeitamente ao humor adotado pelo narrador desde o princípio do texto.

"O Alienista", tendo em vista as teorias apresentadas acima, parece estar um pouco mais próximo da novela do que do conto, sendo assim, optaremos por chamá-lo de novela, até mesmo pela similaridade temática com a "Enfermaria $\mathrm{n}^{\circ}$ 6", que é amplamente aceita como pertencente a esse gênero. No entanto, estamos cientes que "O Alienista" apresenta uma estrutura que transita entre conto e novela.

${ }^{40}$ Ibidem, p. 119. 


\subsection{A publicação de "Enfermaria n" 6"}

Onze anos depois da publicação de Papéis Avulsos, em 1892, Tchekhov publicaria uma das suas mais famosas novelas, "Enfermaria $\mathrm{n}^{\circ} 6^{\prime}$ (Палата $N^{o} 6$ ), originalmente publicada na revista Rúskaia Mysl (O Pensamento Russo).

A novela de Tchekhov obteve grande êxito, os jornais russos da época o elogiaram, viram na "Enfermaria $n^{\circ}$ 6" o grande avanço do autor. Quase não sobrara nada da literatura leve, de riso fácil, do Tchekhov dos primeiros anos. Tchekhov estava no auge da sua carreira, e os críticos consideraram essa novela um marco em sua produção ${ }^{41}$. Tchekhov escreveu este texto após retornar da impressionante viagem que fizera à colônia penal da Ilha de Sacalina em 1890.

Antes de viajar, Tchekhov estudou Direito exaustivamente, e também tornou-se um profundo conhecedor de Sacalina e seu funcionamento como um todo. Ele já havia trabalhado como médico perito em julgamentos. Além de ter um irmão advogado, Mikhail, que o deixava a par do sistema prisional russo. $\mathrm{O}$ autor fez o recenseamento da população da ilha e publicou esse trabalho em 1893, no livro A Ilha de Sacalina, que teve repercussão dentro e fora da Rússia e contribuiu para a reforma do sistema penal do país. Tchekhov voltou de lá um escritor diferente. A "Enfermaria n $\mathrm{n}^{\circ}$ " nasce nesse momento, em 1892, entre a viagem para Sacalina e a publicação do relato. Tchekhov empreendeu a viagem a Sacalina ciente de que estava muito doente e que o trajeto se daria em condições terríveis, já que a linha transiberiana ainda não havia sido construída.

Através de suas cartas, podemos notar que a Justiça e a Medicina eram grandes preocupações para o autor nessa época. Dal-Ri Peres nota que mais do que preocupações, eram obsessões de Tchekhov naquele momento ${ }^{42}$. Médicos e cientistas aparecem com frequência em sua obra: o professor de medicina de "Uma história enfadonha" (Скучная история), о médico da peça “A Gaivota”, o médico da novela "Uma crise” (Припадок).

A frequência com que temas científicos aparecem na obra de Tchekhov deve-se também à moda cientificista, que estava presente em quase todo o Ocidente na segunda

\footnotetext{
${ }^{41}$ Informações contidas no Apêndice elaborado por Boris Schnaiderman para TCHEKHOV, 2007, p. 259.

42 PERES, Paulo Dal-Ri. O Discurso Psquiátrico e anti-psquiátrico de Tchekhov em sua manifestação literária. Tese de doutoramento, São Paulo: USP, 1984.
} 
metade do século XIX. Tchekhov, como médico, devia ter uma preocupação maior quanto ao emprego e a validade dos novos dados científicos.

Em nove de março de 1890, Tchekhov escreve uma carta ao seu editor, Suvórin, na qual responde às dúvidas do editor sobre a viagem a Sacalina. Pelo tom da resposta, o amigo havia achado a viagem uma loucura e tentou dissuadir Tchekhov na carta anterior. No entanto, Tchekhov já estava certo de que iria de qualquer forma. O autor fala da certeza de que sua empreitada não trará nenhuma contribuição valiosa à ciência, nem à literatura, já que terá pouco tempo, contudo diz: "Pretendo apenas escrever umas 100 ou 200 páginas e, com isso, saldar um pouco do meu débito para com a medicina, perante a qual, como é do seu conhecimento, não passo de um porco" ${ }^{\text {43 }}$.

Talvez devido à doença, à própria experiência em meio a injustiças e absurdos, e também pelo fato de que tinha duas profissões, Tchekhov aborda constantemente em suas cartas, sobretudo a partir do final de 1889, o quanto sente-se culpado por não dedicar-se inteiramente à Medicina, sempre diz que está em dívida com a sua primeira profissão. Depois de passar muito tempo estudando a ilha, Tchekhov se convence de que todo ser humano deveria saber dos horrores daquele lugar, talvez tivesse chegado à mesma conclusão quanto à situação dos doentes mentais.

Tendo em vista o teor das cartas de Tchekhov e sua profunda preocupação com a humanidade, ainda que ele, muitas vezes, dissimule, pode-se pensar na "Enfermaria $\mathrm{n}^{\mathrm{o}} 6$ " como uma maneira de saldar parte dessa dívida com a Medicina, que o atormenta. Outros textos, principalmente os mais tardios, parecem ter, em parte, essa mesma função.

$\mathrm{Na}$ "Enfermaria n 6 ", ele demonstra como a inação, presente em todas as esferas da vida russa, é também responsável pelas tragédias diárias daquele povo. Parece ser uma das questões mais importantes para o autor, mostrar que não fazer absolutamente nada em relação às injustiças, assumindo uma postura inerte, é ser conivente, e a maneira como Tchekhov estrutura essa realidade em seus textos, ciclicamente, causa a desesperadora sensação de que nada jamais mudará, num eterno retorno.

A novela é também uma de suas narrativas mais longas, na qual o autor demonstra sua habilidade de articular pequenas situações, construindo uma história mais bem fundamentada.

\footnotetext{
${ }^{43}$ TCHEKHOV, Anton. Cartas a Suvórin: 1886-1891. São Paulo: Edusp, 2002, p. 279.
} 
Seus personagens, assim como em outras de suas narrativas de maior fôlego, são bem estruturados e melhor desenvolvidos psicologicamente.

A "Enfermaria n 6", tal como a encontramos nas edições recentes, tem 66 páginas, e divide-se em dezenove capítulos sem título.

O famoso diretor de teatro V. I. Niemiróvitch-Dântchenko escreveu a Tchekhov: “"Enfermaria $n^{\circ}$ 6' tem um êxito enorme, que o senhor ainda não obtivera. Vê acaso os jornais? É somente dela que tratam"44. Tchekhov, assim como Machado de Assis, fora reconhecido como grande escritor ainda em vida.

Houve divergência nas opiniões da imprensa, na revista Nóvoie Slovo (A Palavra Nova), V. Gólossov escreveu:

Em nenhuma das suas obras anteriores o autor se erguera a semelhante altura de beleza artística e de pensamento sério, profundo e nítido, como no conto 'Enfermaria $n^{\circ} 6^{\prime}$. A simplicidade, elegância e força da linguagem, a vivacidade e intensidade das cores, o respeito à severa causalidade do sucedido, o profundo realismo da psicologia das personagens, e o equilíbrio, a harmonia na construção das partes, a firmeza da perspectiva interior ou, como diria Bielínski, a unidade interior da obra, destacam-se da massa de tudo o que o autor escrever, bem como de todas as obras melhores da literatura russa atual... ${ }^{45}$

Enquanto no jornal Nóvosti (Notícias). A. Skabitchévski escreveu que a novela causava "uma impressão acabrunhante e, em última instância, abaladora", causada

[...] não só pela magistral e profunda análise psiquiátrica do autor, mas também pelo quadro geral da sociedade na cidadezinha longínqua, cuja vida chegara a um tal grau de absurdo generalizado que se perde decididamente a noção de quem, nesse meio pode ser considerado são, e quem deve ser julgado débil mental, e onde termina a 'Enfermaria $n^{\circ}$ 6' e começa a região do bom senso... ${ }^{46}$

Apesar de serem opiniões bastante diferentes elas não são excludentes e apresentam características da novela. Pois, aquilo que diz Skabitchévski não desabona em nada a "Enfermaria $n^{\circ} 6$ ", apenas foca numa outra leitura possível, tudo o que ele disse está na novela e estava também no cotidiano da Rússia, e esse era exatamente o problema.

\footnotetext{
${ }^{44}$ Trecho retirado do apêndice de TCHEKHOV. O beijo e outras histórias. São Paulo: Ed. 34, 2007, p. 261.

${ }^{45}$ Gólossov apud TCHEKHOV, 2007, p. 262.

${ }^{46}$ Skabitchévski apud TCHEKHOV, 2007, p. 262.
} 


\section{Identidade}

O crítico Antonio Candido, em seu famoso ensaio "Esquema Machado de Assis ${ }^{47}$," apresenta algumas linhas de estudo que alguns pesquisadores seguiram e que renderam bons frutos, demonstrando a originalidade e atualidade de Machado de Assis. O item número um, de uma pequena lista de seis, é a questão da construção da identidade. "Quem sou eu? Em que medida eu só existo por meio dos outros? Eu sou mais autêntico quando penso ou quando existo? Haverá mais de um ser em mim?" Essas perguntas feitas pelo crítico parecem estar sendo feitas continuamente na obra de Machado de Assis ("O Espelho", "O Alienista", "Um homem célebre”, “O Segredo do Bonzo”, entre outros).

As mesmas questões são elaboradas de diferentes maneiras por Tchekhov, em contos como "A Dama do Cachorrinho", “A noiva” (Невеста), "Ana no Pescoçо” (Анна на шее), "Queridinha" (Душечка) etc. Esses contos apresentam a relação desses sujeitos com o mundo que os cerca e como eles constroem a sociedade e são, ao mesmo tempo, construídos por ela.

O conceito de identidade é central para esta dissertação, sendo assim, apresentaremos a seguir algumas propostas de definição.

Identidade é aquilo que define o "eu". A diferença é aquilo que o outro é, por exemplo: ela é mulher. Portanto, não é homem. Ao afirmar ser uma coisa, o indivíduo está dizendo que não "é" várias outras. Sendo assim, o "eu" é sempre referência. Apesar de identidade e diferença andarem sempre juntas, a tendência é que o sujeito defina o outro se tomando como exemplo ${ }^{48}$.

Além de serem interdependentes, identidade e diferença têm uma característica em comum: elas são resultado da linguagem. Isso é importante, pois, implica na ideia de que elas não são naturais, não existem antes de serem descobertas, não existem antes da linguagem, são conceitos fabricados através do ato linguístico.

Segundo o linguista suíço Ferdinand Sausurre, os signos que constituem uma língua não têm valor absoluto, não fazem sentido se os considerarmos isoladamente, eles só fazem sentido dentro de uma cadeia infinita de outras marcas gráficas ou fonéticas, que são

\footnotetext{
${ }^{47}$ CANDIDO, Antonio. Esquema de Machado de Assis. In: 1977.

${ }^{48}$ SILVA, Tomaz Tadeu da. "A produção social da identidade e da diferença." In: SILVA, Tomaz Tadeu (org. e trad.). Identidade e diferença: a perspectiva dos estudos culturais. Petrópolis: Vozes, 2000.
} 
diferentes dele. A linguagem, para Saussure, é fundamentalmente um sistema de diferenças, por exemplo, quando dizemos "sou brasileiro", afirmamos que não somos chineses, japoneses ou franceses, e isso implica numa série de outras afirmações que vêm junto com essa simples denominação.

No entanto, a linguagem é instável, indeterminada, o signo é algo que está representando uma outra coisa, que pode ser um objeto concreto, um conceito ligado a esse objeto ou um conceito abstrato, mas a coisa e o conceito não estão presentes no signo. Por ser resultado de um processo de produção simbólica e discursiva, a identidade, e também a diferença, é uma relação social. Elas estão sujeitas a relações de poder, não são definidas de forma harmônica, são disputadas.

Onde existe diferenciação, ou seja, identidade e diferença, também existe o poder. Do processo de diferenciação é que surge a ideia de pertencimento ou não pertencimento; demarcação de fronteiras; a divisão entre bons e maus; puros e impuros; racionais e irracionais; a ideia de normatização, normais e anormais. Essas são oposições binárias, nas quais um dos termos sempre é privilegiado, no caso, as identidades hegemônicas.

Essa divisão do mundo - entre o que é e o que não é - é um processo classificatório, que é central na vida social. As classificações são feitas do ponto de vista da identidade. Aquele que tem o poder de classificar o faz em relação à sua própria identidade, e a partir de uma lógica hierárquica.

A fixação de uma identidade depende de processos sociais, no entanto, esse é um procedimento difícil, quase tão complicado quanto fixar uma palavra, porque, se por um lado existe uma tendência à fixação e à estabilização, existem também forças contrárias a esse movimento. A disseminação de um discurso dependerá da classe que o reproduz.

A ideia apresentada acima, sobre como as identidades surgem, é a chave para a interpretação da loucura em "O Alienista" e na "Enfermaria $n^{\circ}$ 6" proposta aqui. As diferenciações mais tratadas nas novelas são: Interior/Exterior, Eu/Outro, Normal/Doente e Médico/Paciente. Assim como também é importante para a comparação que faremos entre os contos "O Espelho" e "Queridinha", que trabalham essencialmente com questões que envolvem o processo de construção da identidade subjetiva e social.

Podemos dizer que como o "eu" se forma tornou-se uma preocupação a partir do fim da Idade Média, e a ideia de individualidade também surge apenas com a modernidade. Isso 
porque, ao descobrir que Deus não era o centro do Universo, o homem passou a crer que ele mesmo o era. A lógica "Penso, logo existo", de Descartes, colocou o indivíduo no comando de si, desligando-o de Deus. Foucault chama a forma de existência do homem da Idade Média de subjetividade vertical, pois as relações de poder têm origem em Deus.

O homem moderno é formado por outras relações, sua identidade não tem mais origem em Deus, seus laços são efêmeros. As relações de poder passam a ser provenientes de outras forças e não há mais fuga possível, o limite é o seu próprio corpo ${ }^{49}$. Essa forma de existência é chamada por Foucault de subjetividade pontual. Esse sujeito que está no centro dos acontecimentos e é responsável pela sua própria existência é chamado pelo sociólogo Stuart Hall de "indivíduo soberano" "50.

De acordo com Hall, no século XVIII, ainda era possível pensar nos processos da vida moderna centrados apenas no sujeito soberano. Mas, com o crescimento das cidades, a sociedade moderna foi tornando-se mais complexa, organizando-se, aos poucos, de uma forma cada vez mais coletiva. As leis clássicas, depois do processo de industrialização, que levou a um aumento rápido da população, principalmente nos grandes centros, tiveram que ser adaptadas para dar conta dos grandes estados do capitalismo moderno.

No entanto, o indivíduo soberano continuou sendo a figura central dos discursos da lei moderna, reforçando a ideia de que existe um sujeito social e um individual.

Tendo em vista o que foi dito acima, a preocupação com as "identidades" é algo ligado à modernidade e ao surgimento do indivíduo soberano. No entanto, com o desenvolvimento da burguesia, a vida em sociedade exige do sujeito uma nova adaptação que é existir levando em consideração o "outro".

Os indivíduos que aparecem como personagens nas obras de Tchekhov e Machado de Assis são sujeitos sociológicos, são reflexos do crescente mundo moderno e da consciência de que o núcleo interior do sujeito não é autônomo ou autossuficiente, mas formado pela relação com o outro. A identidade não nasce então pronta, formada junto com o sujeito, ela se constrói por meio da interação entre o eu e a sociedade.

\footnotetext{
${ }^{49}$ PEZ, Tiaraju Dal Pozzo. “Pequena análise sobre o sujeito em Foucault: a construção de uma ética possível.” In Anais do VII Sepech - Seminário de Pesquisas em Ciências Humanas - da Universidade de Londrina, 2008.

${ }^{50}$ HALL, 2011.
} 
Ao projetar-se para fora, em identidades culturais, por exemplo, o indivíduo se completa e internaliza significados e valores sociais, que passam a ser parte do que o ser humano é. Seria essa uma maneira de adquirir completude. No entanto, o problema ganha novas proporções quando o sujeito se dá conta de que o mundo social não é fixo, mudanças institucionais e estruturais ocorrem, o que faz com que o "eu" tenha que se adaptar constantemente a novas realidades. Portanto, a ideia de um "eu" unificado é uma ilusão, que se desfez com o crescimento populacional.

O sujeito, a partir da segunda metade do século XIX, terá que lidar com outras questões a respeito do "eu". Por exemplo, o fato de que agora ele não é mais o construtor de si, mas sim o constructo, ou seja, o ponto de partida está no "outro". Passando a ser uma questão importante a alteridade (o outro).

Surge então a noção de que o ser humano é constituído também pelo olhar do outro, pelo contraponto que o outro propõe. A identidade passa a ser então uma atividade coletiva.

Partindo do princípio de que a literatura é um produto da sociedade, podemos dizer que as tensões em torno da formação do "eu” estão presentes também nas obras de Tchekhov e de Machado de Assis, assim como na Rússia já era uma questão presente nas obras de Gógol e Dostoiévski, por exemplo, ainda que o tratamento dado ao tema seja outro. No Brasil, o primeiro a abordar o tema com profundidade foi Machado de Assis, ainda que José de Alencar quisesse falar do homem do seu tempo, seus personagens apresentam uma visão romantizada do mundo e pouco aprofundamento psicológico. 


\section{4. "O Alienista" e "Enfermaria n" 6": duas novelas sobre o mesmo tema}

Dois excessos: excluir a razão, não admitir senão a razão ${ }^{51}$.

Pascal

A loucura é um assunto cercado de mistério, não faz parte do entendimento comum como, nem por qual motivo ela ocorre. Num passado não tão distante, e ainda hoje em menor número, os problemas psíquicos serviram como pretexto para atos variados. Fabricar a loucura onde ela não existe pode ser uma saída para justificar ações extremas daqueles que, de alguma maneira, desrespeitam as normas vigentes.

Na Idade Média, os alienados eram vistos como pessoas com o poder de se comunicar com o além, por isso deveriam ser isolados; após a Revolução Francesa, passaram a ser tratados de uma maneira melhor, pois eram vistos como doentes, mas ainda eram um incômodo para os seus familiares e para a sociedade, que escolhia, na maioria das vezes, enclausurá-los em lugares distantes.

Antes, a internação era uma opção fácil, isolar um ser humano por qualquer que fosse seu transtorno mental era uma escolha da família e, na falta desta, a decisão cabia às autoridades. Afastar o doente sempre funcionou como uma espécie de higiene da cidade e da casa. Assim, a sociedade foi produzindo formas de fabricar a loucura, retirando do convívio os "inconvenientes" sob o pretexto de que eram loucos. Uma vez recebido o diagnóstico de loucura, o discurso do indivíduo é esvaziado de sentido para sempre, e, talvez, essa seja uma prisão maior que o aprisionamento físico. O ser humano perde sua identidade e passa a ser visto como louco, incapacitado para pensar por si mesmo.

A loucura e os avanços da Medicina tornaram-se pauta do dia de quase todas as grandes cidades do mundo entre os séculos XVII e XIX. O crescimento populacional trouxe um aumento de casos de doenças conhecidas, inclusive a loucura, e fez surgir outras, desconhecidas. A doença mental, que sempre figurou nos textos literários - Shakespeare, Cervantes, Erasmo de Rotterdam - tornou-se tema frequente de autores que estavam dispostos a apresentá-la como patologia e demonstrar como ela era concebida pela sociedade da época, expondo qual era o lugar do louco naquele mundo em transição e o papel da psiquiatria naquele cenário de descobertas científicas. É nesse contexto que surgem "O Alienista" e a "Enfermaria no 6".

\footnotetext{
${ }^{51}$ Terceiro pensamento de Pascal, In: BLAISE, Pascal. Pensamentos. São Paulo: Martins Fontes, 2005.
} 
Faremos aqui uma aproximação entre "O Alienista" e a "Enfermaria n" 6", talvez um dos casos mais impressionantes de similaridade entre temas da literatura mundial. Mais espantoso ainda quando lembramos que esta é uma comparação entre obras sem influência direta, porque, como já foi dito, é impossível que Tchekhov tenha lido Machado de Assis e o contrário é pouco provável.

A similaridade tão grande entre os temas de "Enfermaria $n^{\circ} 6$ " e "O Alienista" talvez só seja possível devido à configuração histórica e social da Rússia e do Brasil no final do século XIX. Além do tema principal, que é a loucura, as novelas trazem um elemento novo, que está muito mais ligado ao século $\mathrm{XX}$, a presença do arbitrário como definidor dos destinos. Betina Bischof ${ }^{52}$, assim como outros estudiosos da obra tchekhoviana, nota a excentricidade desses dois grandes temas trabalhados na novela, que são peculiares na obra do autor.

Passemos para um resumo da novela machadiana. $O$ primeiro capítulo de " $O$ Alienista" é intitulado "De como Itaguaí ganhou uma casa de Orates". O termo Orates é de origem espanhola e significa sujeito louco, sem juízo. Sendo assim, trata-se de uma casa de alienados, localizada na pequena vila de Itaguaí.

O protagonista da novela é Simão Bacamarte, filho da nobreza brasileira, grande médico, formado em Coimbra, cidade de Portugal; e Pádua, cidade da Itália, ambas frequentadas naquela época por filhos da elite brasileira, que iam estudar Direito ou Medicina. Dr. Simão havia retornado ao Brasil aos 34 anos. O rei de Portugal não queria que ele viesse embora, mas não conseguiu convencê-lo a permanecer em Coimbra, chegando a lhe oferecer até o cargo de reitor da Universidade de Lisboa. Mas Simão negou tudo, queria voltar para Itaguaí. Casou-se aos 40 anos com D. Evarista da Costa e Mascarenhas, que contava 25 anos, era viúva, e não era bonita nem simpática.

No Brasil, após a tristeza de não conseguir fazer a esposa ter um filho, sua primeira derrota, nota que aqueles que são considerados doentes mentais são afastados do convívio em sociedade, vivem isolados em suas casas: “Assim é que cada louco furioso era trancado numa

\footnotetext{
52 "Um improvável precursor: Tchekhov e Kafka". Literatura e Sociedade, n. 9, São Paulo, DTLLC-FFLCH-USP, 2006, p. 112-123.
} 
alcova, na própria casa, e, não curado, mas descurado, até que a morte o vinha defraudar do benefício da vida; os mansos andavam à solta pela rua ${ }^{53}$.

Ao verificar a situação descrita acima e a falta de um médico psiquiatra em toda a colônia e até mesmo no reino, resolve pedir licença para as autoridades para construir a primeira casa de alienados brasileira. O asilo foi construído na rua Nova, uma das mais belas ruas de Itaguaí, e recebera o nome de Casa Verde. Os loucos passam então a ser capturados na rua e internados de acordo com as teorias sobre a loucura estudadas pelo médico.

Simão Bacamarte gosta da ideia de que, através dele, a ciência lusitana e a brasileira poderiam ficar muito conhecidas. O narrador ironiza a fala de Simão, dizendo que essa exaltação é apenas um "arroubo da intimidade doméstica; exteriormente era modesto". Ora, ninguém que pretende ser o fundador de uma nova ciência, num país distante, é modesto.

A princípio, Simão Bacamarte manda internar na Casa Verde todos aqueles considerados loucos por suas famílias e moradores da cidade. Não havia uma classificação científica clara. Bacamarte pretendia estudar todas as patologias e desenvolver um remédio para todas elas. Conforme começa a observar os doentes e suas moléstias, percebe que existem muito mais doenças do que ele supunha, e todas elas são tipos de "loucura".

Com o tempo, os cidadãos de Itaguaí começam a estranhar o fato de que existem mais doentes do que sãos na vila, já que boa parte da população encontra-se internada na Casa Verde. "Mas, se tantos homens em quem supomos juízo são reclusos por dementes, quem nos afirma que o alienado não é o alienista? ${ }^{54,}$

Tem início então uma revolta da população, que, liderada pelo barbeiro oportunista, irá questionar a autoridade científica de Bacamarte; o plano era destituir o médico do cargo e colocar abaixo a Casa Verde. No entanto, as autoridades públicas decidem que não podem fazer nada, a loucura é um problema da ciência, portanto cabe aos cientistas tomar conhecimento dela, ou seja, a decisão é do médico, único cientista da vila.

Percebendo a quantidade de doentes internados, Bacamarte começa a considerar que talvez seu julgamento estivesse errado, é então que decide soltar todos os que estavam no asilo e mandar prender os que estavam fora da Casa Verde. Todas as pessoas muito boas e cheias de virtudes são internadas, cada doença corresponde a uma perfeição de caráter. Até

\footnotetext{
${ }^{53}$ ASSIS, 2011, p. 40.

${ }^{54}$ Ibidem, p. 68.
} 
mesmo a esposa e o grande amigo do médico, o boticário Crispim Soares, acabam internados na Casa Verde. O médico começa a notar a melhora dos pacientes com alguma facilidade diante de alguns estratagemas propostos por ele. Conclui que, na verdade, não estavam doentes.

Bacamarte então, não querendo acreditar que falhara novamente, começa a pensar que, de fato, talvez ele seja o único louco de Itaguaí, já que era o mais perfeito. Resolve reunir um grupo de amigos para ajudá-lo a decidir a respeito de sua perfeição e todos concordam que ele é perfeito. Sendo assim, encerra-se na Casa Verde em busca da cura de si mesmo, morre meses depois sem alcançar a cura.

A Enfermaria $n^{\circ}$ 6, que dá nome à novela, é uma ala de um hospital que fica numa cidadezinha longínqua da Rússia. Trata-se da narração da história de sujeitos que transitam em torno dessa enfermaria, sendo o principal deles Andréi Iefímitch Ráguin, diretor do hospital, que ocupa o cargo há mais de 20 anos. Ráguin morava no apartamento anexo ao hospital, o que era parte dos benefícios oferecidos ao diretor. Andréi Iefmítch vivia bem, era inteligente, gostava de ler, beber, era sozinho, nunca se casou, a única presença feminina em sua vida é a da empregada Dáriuchka.

Na Enfermaria $n^{\circ} 6$ havia cinco pacientes, todos internados por Ráguin, eram eles: Ivan Dmítritch Gromov, "de condição nobre, ex-oficial de justiça e ex-amanuense provincial, sofre de mania de perseguição", há um homem, sem nome, "alto, magricela, de bigodes ruivos, brilhantes, e olhos de choro"; há o "abobalhado judeu Moissieika", agitado, com jeito de psicopata, pode ir à rua de dia; há um antigo classificador dos Correios; e um mujique “afundado na banha”, sem expressão. Gromov é o único de condição nobre.

Ráguin tem apenas um amigo na cidade, que é o chefe dos Correios Mikhail Avieriânitch, o único contato real com o resto do mundo que o médico tem, já que está sempre voltado para si mesmo, a empregada e os doentes não entram nessa conta, porque ele nunca conversa com eles.

Um dia, durante uma confusão, Andréi Iefímitch é ofendido por Gromov, que, ao ver o doutor, fica espantado com a presença dele na enfermaria e começa a gritar. Então o médico se aproxima do doente e começam a conversar. Ráguin fica admirado com a inteligência do paciente e resolve retornar para continuar a conversa. No entanto, sua atitude causa desconfiança na população, que começa a achá-lo mudado. A partir desse ponto, a vida do 
médico é alterada completamente, e uma rede de intrigas se forma até que ele acaba sendo convocado para um interrogatório.

O interrogatório funciona como uma espécie de julgamento, mas Ráguin já havia sido condenado antes mesmo de entrar na sala para receber a acusação formal. Estão presentes algumas autoridades da cidadezinha, inclusive o médico auxiliar Ievguéni Fiódorovitch Khóbotov, que deseja ocupar o cargo de Ráguin, e o amigo, Mikhail Avierânitch. O grupo recomenda que o médico tire férias.

Mesmo a contragosto, ele acaba aceitando o convite do chefe dos Correios e fazem uma viagem. Quando retorna, descobre que o médico auxiliar já ocupava seu lugar, e só esperava que ele voltasse para se mudar para o seu apartamento.

A Ráguin não é oferecida nem mesmo uma aposentadoria. Sem dinheiro, ele é obrigado a mudar-se para uma pensão de apenas três quartos. Visitam-no apenas o amigo chefe dos Correios e o novo diretor do hospital, Khóbotov.

O novo diretor receita brometo a Ráguin e o amigo aconselha que ele se case. Aos poucos, a situação vai ficando insustentável e, por meio de uma emboscada, Khóbotov conduz Ráguin até o hospital, para, em seguida, encarcerá-lo na Enfermaria $\mathrm{n}^{\circ}$ 6. Uma vez internado, Ráguin percebe o absurdo da situação e faz um escândalo para que o soltem. Notando a confusão, o guarda Nikita, seu antigo funcionário, lhe dá uma surra e Ráguin morre no dia seguinte, de apoplexia.

\subsection{Algumas especificidades do texto literário}

O texto literário é uma criação do escritor, que pode fazer uso da sua imaginação ou da realidade, e pode ainda utilizar os dois para construir sua história. Se o autor opta por usar apenas a imaginação, ainda que tente, dificilmente conseguirá afastar-se totalmente da realidade, isso porque a própria imaginação é composta por suas vivências e memórias. A ficção acaba sendo sempre um misto de realidade e imaginação. A combinação desses elementos depende de como o escritor os utiliza para compor o seu texto, e é neste "como" que o autor demonstra sua originalidade. "Todo texto, artístico ou não, ficcional ou não, 
projeta tais contextos objetuais 'puramente intencionais', que pode referir-se ou não a objetos onticamente autônomos 55 ."

Essa mistura de imaginação, realidade e padrões estéticos constrói um mundo ficcional, que é também um produto da época e funciona como uma espécie de documento de um tempo. Grosso modo, se a literatura é apenas esse documento, costumamos dizer que é datada, que não faz sentido fora daquela realidade que representa, no entanto, se o texto nunca deixa de dizer algo às gerações vindouras, dizemos que ele é uma obra de arte.

A ficção, a rigor, não tem compromisso com a realidade; dentro do universo do texto literário tudo é permitido, desde que os elementos sejam coerentes com a própria composição da obra.

O quanto a realidade é utilizada num texto pode variar de acordo com a época ou com o estilo do autor. Não são apenas os escritores do período do Realismo que escrevem com um compromisso maior de retratar a realidade, assim como nem todos que escreviam naquele período tinham pretensões meramente documentais.

Realidade e ficção se misturam na prosa de Tchekhov e de Machado de Assis, e encontraremos ecos políticos e ideológicos em toda a obra dos dois autores. É possível até perceber claramente, em alguns momentos de suas obras, fatos que muito se assemelham à realidade. Muitas vezes, principalmente na obra do escritor fluminense, é possível até averiguar qual foi a inspiração, ainda que o texto não deixe nunca de ser ficcional. Isso posto, passemos para as comparações.

\subsection{A vila de Itaguaí e a cidadezinha a 200 verstas $^{56}$ da linha do trem}

A vila de Itaguaí é um lugar real, que inicialmente chamava-se Y-tinga e foi descoberta pelos índios no século XVII. Logo após a ocupação indígena, chegou à região a Companhia de Jesus. Os jesuítas construíram uma igreja, onde desenvolveram uma catequese. Não se sabe ao certo a data, mas, posteriormente, a aldeia foi transferida para as terras da Fazenda de Santa Cruz, que ficava mais próxima do oceano.

\footnotetext{
${ }^{55}$ ROSENFELD, Anatol. “Literatura e Personagem”. In CANDIDO, Antonio et. al. A personagem de ficção. São Paulo: Perspectiva, 1964, p. 11.

${ }^{56}$ Antiga medida russa para calcular distâncias, equivalente a 1,067 m.
} 
Nesse novo lugar, os jesuítas ordenaram que os indígenas construíssem um novo templo, agora homenageando São Francisco Xavier. A sede da fazenda de Santa Cruz recebia com frequência a Família Real, que procurava a cidade em busca de tranquilidade. Em 1759, a Companhia de Jesus foi expulsa por Marquês de Pombal.

Como Itaguaí ficava na rota que levava a São Paulo e Minas Gerais, D. Pedro I passou muitas vezes por lá. Dizem as crônicas da cidade, que o imperador havia passado por Itaguaí a caminho de São Paulo para proclamar a Independência do Brasil. O caminho foi batizado de Estrada da Independência. Alguns relatos dizem que D. Pedro I pernoitou em Itaguaí.

Em 1833, a cidade de Santa Cruz foi desligada de Itaguaí e passou a fazer parte do Rio de Janeiro. Entre as famosas lendas do lugar, existe uma que diz que Machado de Assis teria morado em uma fazenda chamada Casa Verde, que anteriormente chamava-se Fazenda Santa Teresa. Há muitas referências quanto à estada de Machado de Assis em Itaguaí, porém, não há documentação que comprove o fato, nenhum dos seus biógrafos obteve provas. A história oficial que a prefeitura de Itaguaí conta em seu site é que o escritor morou por algum tempo na cidade.

O centro da cidade do Rio de Janeiro fica a 73 quilômetros de Itaguaí. No entanto, em "O Alienista" a viagem parece muito mais longa e foi necessária uma comitiva para acompanhar D. Evarista. Além disso, na novela a viagem é tão comprida que nem se cogita ir e voltar no mesmo dia.

Quando se procura por mais detalhes sobre Itaguaí, e mesmo a respeito da ligação de Machado de Assis com a cidade, as histórias parecem todas lendas, que entraram para o imaginário popular. As fontes disponíveis não parecem fornecer informações confiáveis. O site da prefeitura itaguaiense, e mesmo as pequenas citações em livros, não parecem ter certeza da veracidade dos fatos ${ }^{57}$.

Não sabemos ao certo se Machado de Assis esteve ou não em Itaguaí, mas é possível imaginar que ele tenha ouvido falar da cidade e das histórias grandiosas que envolvem sua fundação. Pois, em "O Alienista”, o autor usará o mesmo tom fantasioso que envolve a história de Itaguaí para narrar os eventos fictícios, que aconteceram na cidade após a chegada de Simão Bacamarte. Os fatos são narrados como se fosse pertencessem a uma dessas

\footnotetext{
${ }^{57}$ Informações retiradas do site da prefeitura de Itaguaí: http://www.itaguai.ri.gov.br/?pagina=acidade
} 
histórias que as pessoas gostam de contar sem saber ao certo sua origem, mas que eternizam as tradições locais: “As crônicas da vila de Itaguaí dizem (...)”.

Itaguaí, assim como outras cidades onde se localizam hospícios ou cadeias, fica relativamente perto da capital, mas afastada de seu centro e do convívio com a elite. $\mathrm{O}$ afastamento é propício para que se desenrolem os acontecimentos que se passam tanto na novela de Machado de Assis, como na "Enfermaria no 6", de Tchekhov. Em outras palavras, o cenário isolado parece perfeito para os experimentos de Simão Bacamarte e para a impassibilidade de Ráguin e dos moradores da cidadezinha.

A oposição entre a vila de Itaguaí e o Rio de Janeiro e entre a cidadezinha onde fica a enfermaria e o resto da Rússia são diferentes. Itaguaí é retratada como se fosse um centro, quase como se não existisse um mundo além da pequena cidade. Por exemplo, Simão Bacamarte poderia ter escolhido ser médico ou reitor de faculdade em Portugal, mas preferiu ficar em Itaguaí, já Andrei, diz: “A julgar por tudo, nas nossas capitais, não há estagnação intelectual, existe movimento, quer dizer que deve haver por lá gente de verdade, mas, por algum motivo, sempre nos mandam tais pessoas que nem dá vontade de olhar. Cidade infeliz" ${ }^{, 58}$ - sobre a chegada de Khóbotov.

Nenhum cidadão itaguaiense diria algo semelhante à citação acima. Eles parecem bastante satisfeitos com sua cidade. A harmonia de Itaguaí só é interrompida no momento em que os moradores percebem a falta de critério de Simão Bacamarte para definir quem é louco e quem não é.

Na realidade, a humilde Itaguaí é sempre descrita de maneira grandiosa, como palco de importantes eventos históricos, e Machado de Assis se aproveita dessa característica em sua ficção, ironizando continuamente ao longo da novela dessa peculiaridade. Os eventos que envolvem a vida de Simão Bacamarte e a cidade são tratados com um tom elevado, mas o assunto é banal, cotidiano. Tanto os acontecimentos, quanto os personagens parecem um tanto ridículos, exagerados, clownescos.

O título do capítulo V é "O terror" e o X "A restauração", fazendo clara referência à Revolução Francesa de 1789, equiparando, dessa forma, a Revolta dos Canjicas ao evento francês e Itaguaí à França do século XVIII. No entanto, como notaram vários estudiosos da

\footnotetext{
${ }^{58}$ TCHEKHOV, 2007, p. 215.
} 
obra de Machado de Assis, a Revolta dos Canjicas está muito mais próxima das revoltas que ocorreram no período da Regência (1831-1840): Balaiada, Cabanagem, Sabinada etc.

Entretanto, a arruaça crescia. Já não eram trinta, mas trezentas pessoas que acompanhavam o barbeiro, cuja alcunha familiar deve ser mencionada, porque ela deu o nome à revolta; chamavam-lhe o Canjica, - e o movimento ficou célebre com o nome de revolta dos Canjicas. A ação podia ser restrita, — visto que muita gente, ou por medo, ou por hábitos de educação, não descia à rua; mas o sentimento era unânime, ou quase unânime, e os trezentos que caminhavam para a Casa Verde, dada a diferença de Paris a Itaguaí, — podiam ser comparados aos que tomaram a Bastilha. $^{59}$

Enquanto Itaguaí é comparada a Paris, Andréi Iefímitch diz da cidadezinha: "Uma ignomínia como a Enfermaria $\mathrm{n}^{\circ} 6$ é possível unicamente a duzentas verstas da estrada de ferro, uma cidadezinha..."60

O médico idealiza aquilo que está distante, sonha com um mundo de possibilidades, onde colocaria seus pensamentos em prática e estaria no centro do movimento intelectual, como ele mesmo diz. E esse lugar não é a cidadezinha onde está localizado o hospital. Ráguin acha que viver ali é um desperdício de sua capacidade intelectual, seria melhor viver numa cidade grande, no entanto, isso é apenas uma ilusão, ele está sempre sonhando com um lugar melhor.

A cidade onde fica o hospital não tem nome, possui poucos prédios e casas, compõem o cenário: a prefeitura, a penitenciária, o correio, a escola, o clube, a igreja, o tribunal, o ziemstvo, a fábrica de farinha de ossos, a loja judia, a vendinha, a casa do pai de Gromov, a casa de um pequeno burguês, o cemitério, todos sem grandes descrições. A única construção da cidade bem definida é o hospital, que tem farmácia, ambulatório, enfermaria para doenças venéreas e a Enfermaria n ${ }^{\circ}$, que é a ala reservada aos loucos.

Apesar de as casas não serem descritas, por uma economia dos meios narrativos, traço típico da literatura de Tchekhov; a casa do médico, que é a mais rica da cidadezinha e fica dentro da construção que abriga o hospital, é apresentada mais detalhadamente, tem seis cômodos. Quando Ráguin é obrigado a mudar-se para a casa da pequeno-burguesa Bielova, após ser destituído do seu cargo, ficamos sabendo que ela mora numa pensão com três quartos e que acomoda, com Ráguin, seis moradores.

\footnotetext{
${ }^{59}$ ASSIS, 2011, pp. 68-9

${ }^{60}$ TCHEKHOV, 2007, p. 208.
} 
Simão Bacamarte, ao contrário de Ráguin, nunca esboça o desejo de ir a outro lugar, está certo de que melhor cidade não há, nem outro país. A vila de Itaguaí funciona para ele como um pequeno reino, ainda que ele afirme que seus objetivos são apenas científicos, é lá que ele faz fortuna, à custa dos loucos; vive em uma casa bonita; é respeitado por todos, nem mesmo as autoridades ousam desafiá-lo. A autoridade científica que Bacamarte representa é máxima, não há ninguém acima dele na novela. Bacamarte não quer viajar, não sai de Itaguaí nem mesmo para acompanhar a esposa até a cidade do Rio de Janeiro, prefere que ela vá com os amigos e a tia.

O clima de absurdo que cerca as duas narrativas, e que parece estar essencialmente ligado à lógica das cidades, é desenvolvido de forma diferente. Em Itaguaí, o absurdo vai sendo pouco a pouco construído. A princípio parece uma cidade como outra qualquer, mas os acontecimentos que vão se desenrolando ali transformam-na num cenário que causa uma sensação de estranhamento, que só aumenta ao longo da narrativa. O tom de lenda prepara o leitor para aceitar tudo. Assim, o narrador vai construindo a sua história, que tem como centro Simão Bacamarte e os estudos psiquiátricos desenvolvidos por ele na cidade, começando com a fundação da Casa Verde. O absurdo se estabelece gradualmente: primeiro ele funda um manicômio sozinho, depois coloca a maior parte da população lá, a seguir muda de ideia e coloca na Casa Verde aqueles que estavam fora etc.

A inação dos moradores de Itaguaí diante dos desmandos de Bacamarte termina quando eles começam a desconfiar das boas intenções do médico, e é assim que resolvem organizar uma revolta, contra ele e a Casa Verde. Este também acaba sendo um movimento sem sentido, porque o objetivo inicial é perdido rapidamente. O barbeiro Porfírio manipula a população para tomar o poder administrativo da cidade, demonstrando que os moradores são facilmente manipuláveis, até mesmo os militares.

Na cidadezinha da novela de Tchekhov a atmosfera é outra, encontramos o absurdo instalado, não é o médico que faz com que aquelas ações sejam colocadas em prática, mas, uma vez que não tem coragem, nem disposição para mudar alguma coisa, ele passa a fazer parte de uma engrenagem que acabará por destruí-lo. O centro da narrativa e da cidadezinha é a Enfermaria $n^{\circ}$ 6, não o médico, o contrário se dá em "O Alienista", que tem toda a sua ação centrada na figura de Simão Bacamarte. 
$\mathrm{Na}$ "Enfermaria $\mathrm{n}^{\circ}$ 6", os acontecimentos são narrados no presente, não como uma lenda, mas como fatos cotidianos. A história narrada em primeira pessoa, no presente, e o uso do discurso indireto aumentam a sensação de casualidade.

Não sabemos onde está localizada a cidade da novela de Tchekhov, apenas que fica a duzentas verstas da linha do trem, o que sugere que aquilo que se passa ali não acontece em nenhum lugar específico, mas em toda parte, trata-se de uma história alegórica. "O Alienista", apesar de ter uma construção diferente, com outro tipo de andamento narrativo, também pode ser lida como uma história alegórica.

A cidade da novela de Tchekhov parece quase desabitada, não há referência a muitos moradores. As poucas pessoas que aparecem têm alguma relação com o hospital. A população de Itaguaí parece grande para os padrões da época, e é em número suficiente para fazer um levante, trezentas pessoas se juntaram a Porfírio na Revolução dos Canjicas.

Enquanto a população de Itaguaí organiza um levante, os moradores da cidadezinha buscavam explicações estapafúrdias para aquilo que acontecia no hospital, diziam que se tratava de um lugar em que só mujiques e pequenos-burgueses eram tratados, então deveriam ficar contentes porque na casa deles a situação devia ser pior, o que não era verdade, Gromov, por exemplo, era nobre.

Ao final, os moradores das duas cidades são muito parecidos, facilmente manipuláveis pelo discurso científico proferido pelas autoridades. Todos têm como objetivo a autopreservação e a garantia dos seus direitos.

As situações e justificativas higienistas dadas pela população da cidadezinha para ignorarem aquilo que acontece no hospital se assemelham muito àquelas dadas para as condições dos presos. Assim como na prisão, os pacientes não são tratados com o fim de reabilitá-los para serem devolvidos para o convívio em sociedade, o que ocorre é um sistema de degradação, que tem por objetivo apenas encarcerar o indivíduo, isolando-o da sociedade até a sua morte, em muitos casos.

Itaguaí parece uma cidade mais feliz, mais povoada e pronta para adorar Simão Bacamarte, enquanto a cidadezinha na Rússia é mais soturna, lembra muitas vezes o cenário de um filme de suspense em que acontecimentos estranhos e isolados desenrolam-se ao longo da trama, e, ao final, é revelado que tudo estava interligado. 
Ráguin e Simão Bacamarte são forasteiros nas cidades em que trabalham, vieram exclusivamente para praticar o ofício de médico, são, portanto, elementos estranhos introduzidos em pequenas cidades para representar a autoridade científica. Essa relação tornase problemática quando os moradores precisam enxergar além da profissão, não há nenhum laço de afeto entre os moradores da cidadezinha e Ráguin, assim como não há entre Simão e Itaguaí, nos dois casos, o discurso científico está acima de qualquer julgamento, e é dessa forma que Ráguin é internado e Simão também, a diferença é que o próprio Simão é a autoridade que decide pela própria internação, e Ráguin fora destituído do cargo de autoridade científica da cidadezinha através de um estratagema.

\subsection{A Enfermaria $n^{0} 6$ e a Casa Verde}

Há na sala camas aparafusadas ao soalho. Nelas estão sentadas ou deitadas pessoas de roupão hospitalar azul e de barrete de dormir, à antiga. São dementes.

Tchekhov

A Enfermaria $n^{\circ}$ 6, que também dá nome à novela, é a ala de doentes mentais do hospital localizado na cidadezinha sem nome, onde está ambientada a narrativa de Tchekhov. E então aparece uma das diferenças mais importantes quando comparamos as duas novelas, enquanto a história de Tchekhov recebe o nome do local onde os eventos narrados se passam, em "O Alienista", temos como título o personagem mais importante da novela, o centro convergente, Simão Bacamarte, mas não o seu nome, a sua profissão, que é o que ele representa na vila de Itaguaí.

No primeiro capítulo da novela de Tchekhov, temos a apresentação do hospital, seu exterior e seu interior. Uma imagem panorâmica é apresentada ao leitor, com close em alguns detalhes: telhado enferrujado, chaminé meio desabada, degraus da entrada apodrecidos. $\mathrm{O}$ narrador parece caminhar pelo hospital e descrever, como se estivesse num tour, aquilo que vê. O hospital é separado do campo por um muro cinzento coberto de pregos "O muro e o próprio pavilhão têm o aspecto tristonho e maldito que em nosso meio é exclusivo dos edifícios hospitalares e carcerários ${ }^{61}$."

A Casa Verde, manicômio fundado por Simão Bacamarte, é apresentada de maneira diversa da Enfermaria $n^{\circ} 6$, a começar pelo nome, que recebeu devido à cor de suas janelas,

\footnotetext{
${ }^{61}$ TCHEKHOV, 2007, p. 183.
} 
mas que também faz alusão a uma ideia positiva do lugar. A imagem de um palácio bonito, com cinquenta janelas verdes de cada lado, com um pátio central, localizado na rua mais bela da cidade, é reconfortante, é exatamente o oposto do ambiente hostil do hospital da novela de Tchekhov.

A descrição do hospital da "Enfermaria no 6" é assustadora: no pátio há um pequeno pavilhão, onde há plantas malcuidadas, crescendo em desordem - bardanas, urtigas e cânhamo selvagem. A natureza, que costuma aparecer na obra de Tchekhov como elemento harmônico, aparece como repelente. Não são plantas com as quais o ser humano está acostumado a conviver, elas são selvagens, e estão invadindo um espaço restrito à ciência, uma construção, como se o prédio estivesse completamente abandonado.

O sentimento de repulsa é crescente, quanto mais o narrador descreve o ambiente, maior é o asco. A sensação é de que tudo exala um cheiro terrível de coisa apodrecida. A narração recorre ao discurso indireto, que aproxima o leitor do objeto narrado e causa maior efeito de realidade.

Roupas, utensílios e sapatos apodrecem em pilhas no hospital. Na Enfermaria $n^{\circ}$ 6, há grades nas janelas, o cheiro é de chucrute misturado a pavio queimado, percevejos e amoníaco, o narrador compara ao cheiro de zoológico. Os pacientes estão vestidos de roupão hospitalar azul e gorro de dormir antigos, e as camas estão aparafusadas ao chão.

A narrativa em "Enfermaria $n^{0} 6$ " se dá em dois planos, um linear, em que os acontecimentos vão se desenrolando de maneira articulada e numa progressão narrativa cronológica, que parece ter a finalidade única de contar uma história com começo, meio e fím. No entanto, num segundo plano mais subjetivo, os acontecimentos se dão à revelia, com algumas intensificações e exageros para construir uma narrativa em que também o estranhamento é crescente. A calmaria da cidade diante do horror que representa o hospital, especialmente a Enfermaria $n^{\circ} 6$, vai se tornando angustiante. Conforme a novela avança, o desconforto aumenta e a aparição de adjetivos negativos como "maldito", intensificam essa má impressão.

A palavra russa "palata" (Палата), utilizada por Tchekhov para nomear a novela, tem vários significados: palácio, edifício grandioso; em sentido figurado, uma pessoa muito sábia; instituições, como Câmara Legislativa, Câmara do Comércio, entre outras. Quando diz respeito a instalações hospitalares, significa enfermaria, pavilhão. O que demonstra que 
diversos significados estão atrelados a essa palavra: é o espaço do poder, da cura, da justiça, da sabedoria.

Os nomes usados nas duas novelas para designar o hospício - "Casa Verde" e "Enfermaria $n^{\circ} 6 "$ sugerem ironia e ambiguidades. Adjetivos como carcerário e hospitalar aparecem com frequência no texto de Tchekhov. Ráguin compara o hospício a uma "prisão".

Quando o personagem Mateus é recolhido à Casa Verde, dizem: “a Casa Verde é um cárcere privado". Ideia que logo se espalhou, toda a população começou a repetir essa frase, mas com cautela. Os moradores começaram a sentir medo de Simão Bacamarte, eles achavam que se ele soubesse o que estavam dizendo, como vingança, encerraria a todos na Casa Verde. O que não era verdade, porque Bacamarte acreditava estar se guiando apenas pela ciência, que estava acima de tudo para ele, inclusive de pequenas vinganças.

Na novela de Machado de Assis, o primeiro hospício brasileiro é criado por Simão Bacamarte. Fora da ficção, o primeiro hospício do Brasil foi criado por José Clemente Pereira, que desembarcou no Brasil em 1815. Assim como Bacamarte, ele estudou na Universidade de Coimbra, mas formou-se em Direito. Viveu no Rio de Janeiro como advogado até dar início à carreira pública. Em 1838, tornou-se provedor do Hospital da Santa Casa da Misericórdia, e transformou sua gestão em vitalícia. José Clemente Pereira administrou a instituição até a sua morte em 1854.

Tendo em vista o aumento dos casos de doentes mentais, em 1830, a Comissão de Salubridade da Sociedade de Medicina do Rio de Janeiro foi a primeira a questionar o tratamento dado aos alienados brasileiros. A população apoiou a Comissão, mas diferentemente dos médicos, desejava o fim do convívio com loucos, o afastamento definitivo dessas pessoas da sociedade ${ }^{62}$.

José Clemente Pereira, antes de ocupar o cargo na Santa Casa, já havia apresentado um projeto no qual propunha uma reforma significativa para a instituição. De acordo com o projeto, deveriam ser criadas unidades especializadas em cada doença. Ele também é conhecido por ter sido o líder do Dia do Fico, movimento popular ocorrido em nove de janeiro de 1822, que exigia a permanência do príncipe regente no Brasil.

\footnotetext{
${ }^{62}$ ANTUNES, Eleonora Haddad; e outros. Psiquiatria, Loucura e Arte: Fragmentos da História Brasileira. São Paulo: Edusp, 2002.
} 
Em 1841, D. Pedro II teve sua maioridade decretada com apenas 14 anos e foi declarado rei do Brasil, dois anos após José Clemente ter assumido o cargo de provedor da Santa Casa de Misericórdia ${ }^{63}$.

Seguiram-se muitos eventos em comemoração à coroação do novo rei, e então foi criado o hospício, que acabou levando o seu nome. O Hospício D. Pedro II ficava anexo ao Hospital da Santa Casa de Misericórdia. As obras começaram em 1842 e só seriam concluídas em 1852. A Casa Verde também "inaugurou-se com imensa pompa; de todas as vilas e povoações próximas, e até remotas, e da própria cidade do Rio de Janeiro, correu gente para assistir às cerimônias, que duraram sete dias".

O reinado de D. Pedro II ficou conhecido pelas inúmeras festas que ele fazia para comemorar toda sorte de datas e acontecimentos, daí a ironia de Machado de Assis ao descrever o evento que oficializou a abertura da primeira casa de alienados de Itaguaí.

O primeiro hospício brasileiro foi inaugurado quase simultaneamente às instituições dessa natureza na Europa, e estava de acordo com a regulamentação francesa, o que fez do Brasil um dos poucos países que se preocupava com a situação de seus alienados, o que era sinal da modernidade do país ${ }^{64}$.

Como todos os hospitais psiquiátricos do mundo naquela época, o Hospício D. Pedro II localizava-se longe dos grandes centros. O hospício era um palácio, menor apenas que a Santa Casa de Misericórdia, ficava na, hoje famosa, Praia Vermelha. Atualmente, as antigas instalações do hospício são ocupadas pela Universidade Federal do Rio de Janeiro. Hoje, quando pensamos no afastamento, tendemos a compreender o fato apenas como um movimento da sociedade para isolar aquelas pessoas que perturbavam o cotidiano da cidade, no entanto, não se trata apenas disso, Jean-Étienne Dominique Esquirol (1772-1840) ${ }^{65}$, conhecido como criador do modelo de hospício daquele período, defendia a distância da cidade, e a proximidade do mar ou do campo, porque os ares, a temperatura, a calmaria, o contato com a natureza eram propícios para a cura. A ideia é que o hospital fosse afastado das grandes aglomerações, mas não muito longe do centro. Como Itaguaí, que fica a setenta quilômetros do centro do Rio de Janeiro.

\footnotetext{
${ }^{63}$ SEGAWA, Hugo. “Casa de Orates." In: ANTUNES, 2002, pp. 55-80.

${ }^{64}$ ASSIS, 2011, p. 42.

${ }^{65}$ FOUCAUL, Michel. História da Loucura. São Paulo: Perspectiva, 1978.
} 
Somente na primeira metade do século XX, começaram a surgir ideias a respeito da inserção de hospitais psiquiátricos na área urbana. No mesmo período, apareceram as primeiras sugestões sobre a necessidade dos hospitais se assemelharem o mínimo possível a prisões - sem grades.

Na época da fundação do Hospício D. Pedro II, estava em voga uma arquitetura hospitalar que deveria facilitar o sistema classificatório. No entanto, num momento posterior, observou-se um exagero na classificação, o que fez com que os médicos considerassem o Hospício D. Pedro II não funcional.

O famoso arquiteto Louis Cloquet propunha no início do século XX uma arquitetura para os hospícios na qual não existisse vigilância central, os doentes deveriam ser dispersados, desfavorecendo assim o esquema de classificação dos doentes e favorecendo a identificação de novas patologias.

O objetivo dessa breve apresentação de José Clemente Pereira não é fazer uma aproximação dele e Simão Bacamarte, mas sim mostrar como a questão do surgimento da figura do psiquiatra e do hospício era um assunto então em voga. A construção do Hospício D. Pedro II, que demorou dez anos para ser concluída, foi assunto da sociedade carioca durante todo esse período. Era importante que fosse grandioso, pois levava o nome do imperador, deveria seguir os padrões europeus, para que o Brasil fosse admirado pelo seu feito. Um país na periferia do mundo com um hospício de alto padrão.

Todos esses elementos da História do Brasil aparecem em "O Alienista", em que Simão Bacamarte, no seu delírio de grandeza, sonha tornar a pequena Itaguaí num centro de referência científica.

Assim como acontece com a Casa Verde, a Enfermaria no 6 é comparada à Bastilha, prisão símbolo do despotismo do regime monárquico francês, e que foi tomada pelo povo em 14 de julho de 1789, dando início à Revolução Francesa. A Casa Verde é chamada pelo barbeiro Porfírio de "Bastilha da razão humana", expressão que ele ouvira de um poeta e que soou muito bem por ocasião da Revolta dos Canjicas, que queria o fim da opressão exercida pelo alienista e sua Casa Verde.

\subsection{A loucura}


Como já foi dito antes, o tema principal de "Enfermaria no 6" e "O Alienista" é a loucura. Nos dois casos, o modelo psiquiátrico do século XIX e toda a revolução causada por esse modelo, na Rússia e no Brasil, são transformados em temas literários por Tchekhov e Machado de Assis, cada um a seu modo.

A Medicina é um assunto que figura com alguma frequência nos textos tchekhovianos desde o início de sua carreira, no entanto, o tipo de exposição apresentada pelo autor na "Enfermaria $n^{\circ}$ 6" não é muito comum em sua obra, aproximando-se muito da estrutura do conto filosófico ao abordar temas como o Positivismo, o Materialismo, a Medicina Moderna, a função da psiquiatria, a condição do louco e o absurdo presente no cotidiano.

Tchekhov tinha uma concepção especial da Medicina. Em alguns dos seus contos, fala dela com a experiência de quem passava a vida atendendo todo o tipo de pessoas como médico; em outros, retrata profissionais que representam aquilo que ele abominava na Medicina, como o descaso, a falta de interesse pelo outro, a automatização do atendimento, a indiferença aos sentimentos dos pacientes.

Machado de Assis não era médico, mas, assim como Tchekhov, era um escritor muito atento às questões do seu tempo. Certamente, "O Alienista" apresenta o retrato do autor da condição da loucura e do doente mental no Brasil. A loucura é um tema frequente na literatura machadiana, presente em alguns dos seus contos, também aparece como um dos temas centrais do romance Quincas Borba (1892).

Segundo Foucault ${ }^{66}$, as concepções de loucura mudam de acordo com o momento histórico: na Idade Média, devido à forte influência da religião, a loucura era vista como uma manifestação primitiva, e o louco seria capaz de fazer revelações terríveis; para os humanistas a loucura perde esse caráter místico, em que o louco é considerado uma espécie de oráculo, capaz de interagir com o além, e passa a ser visto como o sujeito "sem razão", mas ainda não como um doente; na França, após a Revolução, a Medicina passa a contemplar a loucura, que se torna uma patologia. Surgem as ideias de Philippe Pinel, Jean-Étienne Dominique Esquirol e Jean-Martin Charcot $^{67}$.

Na Idade Média, o louco carregava uma aura de mistério, como se ele tivesse conexão com um mundo que os "normais" não conhecem. Os alienados foram tratados durante muito

\footnotetext{
${ }^{66}$ Ibidem.

${ }^{67}$ SEGAWA, 2002.
} 
tempo como endemoniados pela Igreja, que prescrevia exorcismo em alguns casos. $\mathrm{O}$ personagem Gromov, que aparece na "Enfermaria no 6", é descrito como um espírito mau e zombeteiro. Na novela de Tchekhov, as autoridades têm a mesma concepção de loucura que existia na Idade Média.

Quando Ráguin é interrogado a respeito de sua amizade com Gromov, perguntam a ele se é verdade que na Enfermaria $n^{\circ} 6$ vivia "um profeta admirável", ressaltando esse misticismo em torno do louco. Gromov seria capaz de, através da sua ponte com o outro mundo, prever o futuro. A pergunta é irônica e desrespeitosa com o médico, já que está sendo feita com o intuito de comparar Ráguin com Gromov.

Na literatura russa, podemos notar que, em alguns períodos, ser considerado um profeta era algo positivo. Como o iuródivyi, misto de tolo, vidente e mendigo, figura importante no romance $O$ Idiota de Dostoiévski. Essas pessoas eram tratadas com respeito e simpatia, mas, com o passar do tempo, a visão foi mudando, com o surgimento da psiquiatria e dos asilos para loucos, passaram a ser consideradas doentes mentais, o que seria bom, se a população não quisesse evitar o convívio com os doentes. No entanto, a mistificação em torno da figura do louco, que representa um atraso nos estudos psiquiátricos da Rússia em relação à Europa Ocidental, continua prevalecendo. Gromov não está encerrado no hospital para que se cure, mas porque não é "bom" para a sociedade ter uma pessoa como ele na rua. Trataremos melhor dessa questão adiante.

O alienista ou psiquiatra surge então com uma função muito clara na sociedade: saber reconhecer os alienados, aqueles desprovidos de função social, os que não se comportam como o esperado, os "sem razão", para que sejam afastados do convívio com os "normais".

Apenas na primeira metade do século XIX, os asilos são transformados em hospitais, mas os doentes continuam excluídos. A criação dessas instituições representou um avanço em relação à condição anterior porque a loucura passou finalmente a ser tratada como doença e não como uma maldição.

Após a Revolução Francesa com seus ideais humanistas, surgiu o famoso psiquiatra Philippe Pinel (1745-1826), o primeiro médico a tentar classificar e descrever as doenças mentais, agrupando-as em quatro categorias: "manias" ou delírios gerais, "melancolias" ou "delírios exclusivos", "demências" e "idiotias". Foi ele que cumpriu a importante missão de 
dizer à sociedade que os alienados eram doentes, fazendo a distinção entre possíveis pacientes e criminosos.

Num segundo momento, os médicos Valentin Magnam (1835-1916) e Paul Sérieux (1864-1947) retomam a classificação de Esquirol, e apresentam uma lista de evolução dos delírios: período de incubação, período de perseguição (quando o delírio é organizado), período ambicioso (delírio de grandeza), período de demência (fim dos delírios) ${ }^{68}$.

A psiquiatria desse período foi fortemente influenciada pelo Positivismo Naturalista, é assim que surgem as intermináveis listas. O Positivismo defendia que a ciência só pode lidar com entidades observáveis, conhecidas diretamente através da experiência. O Positivismo tenta formular leis ou teorias gerais que expressem relações entre fenômenos. Através da observação é decidido se um fenômeno se enquadra ou não na teoria.

Cada doença, a partir do empirismo, deve receber uma descrição clara e ser catalogada, dessa forma, os alienistas acreditavam que um dia teriam todas as doenças detectadas, bastaria então procurar uma cura para cada uma delas, e então toda vez que surgisse um doente com determinados sintomas, era só tratá-lo segundo o seu diagnóstico.

Todos os procedimentos médicos descritos em "O Alienista" ironizam, por meio do exagero, as práticas da medicina positivista em voga na época. Se a intenção de Simão Bacamarte fosse desenvolver um estudo e guiar-se por ele e por novos estudos que saíssem em revistas de medicina, por exemplo, seria ótimo, mesmo não sendo o ideal. No entanto, à medida que não conseguia fechar uma lista com todas as doenças e sintomas, precisava reelaborar frequentemente a classificação das doenças.

A princípio, o alienista classificou os enfermos dividindo-os em duas classes principais: os furiosos e os mansos; daí passou às subclasses, monomanias, delírios, alucinações diversas; num segundo momento, analisava todos os hábitos do louco e queria saber todos os antecedentes de cada paciente. A partir dos dados recolhidos, ele montava uma lista de sintomas ligados a cada moléstia e estudava qual seria a melhor medicação a administrar. Para tanto, apoiava-se em antigos tratados árabes.

Os moradores de Itaguaí iam dormir sãos e amanheciam classificados como "loucos", segundo a lista de sintomas mais recente do alienista. Ele passa o observar as pessoas,

\footnotetext{
${ }^{68}$ Ibidem.
} 
tornando todos suspeitos, como se fossem criminosos. Basta um deslize para que Simão mande encarcerar qualquer pessoa, não há exceções, nem predileções, até mesmo a esposa e o amigo boticário foram parar na Casa Verde.

Com a criação do hospício, os doentes mentais têm um lugar para onde ir a fim de receber atenção médica. No entanto, num primeiro momento, a internação não tem como objetivo a cura do paciente, mas afastar do convívio social as pessoas incômodas.

Assim são todos os pacientes da Enfermaria $n^{\circ}$ 6, pessoas que estão à margem da sociedade por algum motivo. A loucura é caracterizada na novela pela perda do trabalho. Como é bem pontuado pelo narrador, são mujiques ou pequeno-burgueses, por isso não é necessário preocupar-se com eles. Na novela de Tchekhov, os moradores da cidadezinha não se importam com os internados na enfermaria e desejam que os doentes fiquem trancafiados principalmente por serem pobres, não loucos. Esses doentes estão em situação de miséria porque não são capazes de produzir seu próprio sustento, sendo assim são encerrados num hospital, como estorvos.

O processo para que cada sujeito fosse considerado louco e deixado ali é o mesmo: Moissiéika fica louco após um incêndio que destruiu sua oficina de chapeleiro, Gromov perde seu emprego e muda-se para uma pensão antes de ser internado, e o médico também, após perder seu emprego, vai morar em uma pensão, depois disso, vão parar na enfermaria. A partir desse momento, são internados, privados de tudo aquilo que os torna indivíduos: vestem roupas iguais; a comida é dada no mesmo horário para todos; quando desobedecem, apanham do vigia Nikita etc.

Charles Darwin (1809-1882) é um dos responsáveis pela onda de ideias científicas que se espalhou pelo mundo, seus estudos foram decisivos para a formação do pensamento do período. O naturalista inglês publicou a primeira edição de A Origem das Espécies em 1859 e os principais conceitos de seus estudos rapidamente se popularizaram, praticamente todo homem culto do período teve suas convicções abaladas ou confirmadas por essa obra. Os escritores que começaram a escrever depois da publicação desse livro eram influenciados por ele, seja para ratificar suas teorias ou para contestá-las. O fato é que não havia como ignorar sua existência. O Realismo e o Naturalismo são as duas escolas literárias que foram mais fortemente influenciadas pelos estudos de Darwin, sendo que o Naturalismo pode ser considerado um produto mais direto das primeiras ideias difundidas pelo naturalista inglês. 
A partir dos estudos de Darwin sobre a origem das espécies, o homem foi incluído na mesma escala evolutiva dos animais, diferenciando-se destes pela Razão. O sujeito considerado "louco" é aquele que não se enquadra nas normas da razão, portanto, representa um desvio do padrão da espécie. Sendo assim, da mesma forma que a origem das espécies foi explicada por Darwin, destruindo a ideia de que todos os seres vivos foram criados por Deus, não fazia mais sentido acreditar que a loucura, assim como todas as doenças, fosse algo místico. O desvio do padrão passa então a ser visto como doença.

Esse processo de naturalização das doenças valorizou a figura do médico, que passou a ser o profissional responsável pela "cura" de todos os males do corpo e da mente.

A Medicina torna-se então quase uma religião e o médico é seu Deus, do qual ninguém pode duvidar. Isso fica muito claro na novela de Machado de Assis: Simão Bacamarte está acima do bem e do mal e é autoridade máxima. Ninguém duvida do médico, ele é objeto de adoração. Já na novela de Tchekhov, Ráguin era um instrumento das autoridades, pago para manter tudo funcionando exatamente como antes, a ninguém interessava um médico que quisesse fazer uma revolução na psiquiatria, no entanto, ele só se dá conta do esquema ardiloso do qual participava, quando é chamado para o interrogatório. Como médico, Ráguin também era respeitado, o que podemos notar pelo tratamento dado a ele pelo vigia Nikita, que o chama de "Vossa Alta Nobreza". Ele é a marionete que representa a autoridade científica.

Segundo Foucault, a partir das várias crises que abalaram o final do século XIX, o poder do médico passou também a ser questionado. O médico era visto até então como detentor da verdade, no entanto, o seu julgamento não está livre de contaminação pelo poder que lhe é dado.

Além do evolucionismo de Darwin, duas teorias foram particularmente importantes para o Realismo e para o Naturalismo: o determinismo de Hippolyte Taine (1825-1893), que acredita que o comportamento humano é determinado pela hereditariedade, pelo meio e pelas circunstâncias; e o Positivismo de Auguste Comte (1789-1857), que, aplicando o conceito de evolução ao pensamento humano, desenvolveu a tese de que a humanidade estaria entrando num terceiro ciclo de evolução, o ciclo positivo da era científica, depois de ter passado pelo 
ciclo teológico e pelo metafísico, segundo essa teoria o único meio de atingir o conhecimento válido são a observação, a experimentação e a comparação ${ }^{69}$.

As três teorias citadas acima influenciaram profundamente todas as áreas do pensamento na segunda metade do século XIX.

\subsubsection{A loucura como identidade}

O que é ser louco? Como definir o que é loucura? Como diagnosticar?

A loucura é uma identidade, que, por diferenciação, define aquele que não possui "razão", ou sensatez, e, num sentido mais contemporâneo, é aquele que sofre de algum tipo de perturbação psíquica. Em "O Alienista”, basta uma simples mudança de comportamento, um discurso "estranho", a apresentação de um sintoma da lista elaborada por Bacamarte para ser considerado louco. O maior problema nesse caso é que essa lista é instável e foi elaborada por uma única pessoa. Na "Enfermaria n ${ }^{\circ}$ 6", a perda de emprego gera a incapacidade de prover o

próprio sustento e isso leva uma pessoa a ter atitudes consideradas estranhas, o que é rapidamente considerado loucura, sempre nessa ordem.

A loucura, como identidade construída na segunda metade do século XIX, é utilizada para denominar não só os doentes mentais, mas também todos aqueles que não são criminosos, mas que estão à margem da sociedade por algum motivo - miséria, alcoolismo, deficiência física -, tornando-se necessário afastá-los do convívio, principalmente urbano. Ser internado em um hospício, na maioria dos casos, não tem ligação com um diagnóstico médico. Nessa perspectiva, o "louco" é todo aquele que apresenta algum desvio em relação ao padrão socialmente aceito ${ }^{70}$.

$\mathrm{Na}$ "Enfermaria no 6" e em "O Alienista" apresenta-se um cenário em que os indivíduos são divididos em duas grandes categorias: existem as pessoas normais (racionais) e as pessoas que perderam a razão, os doentes; portanto, possíveis pacientes, e a única forma de tratamento é a internação.

O problema é determinar o que estabelecerá essa fronteira: qual atitude seria definitiva para que um indivíduo fosse considerado alienado?

\footnotetext{
${ }^{69}$ BOSI, 2006, pp. 163 a 173.

${ }^{70}$ SZASZ, Thomas. A fabricação da loucura. Rio de Janeiro: Jorge Zahar, 1983.
} 
Na novela machadiana, Simão Bacamarte mudará de ideia duas vezes, Ráguin não "pode" fazer o mesmo, o processo que decide quem é louco e quem não é já está estabelecido antes da sua chegada à cidadezinha, ele é apenas um encarregado, deve fazer tudo funcionar exatamente como antes, mas não deixa de ser o responsável por distinguir os doentes dos sãos.

Quando Ráguin começa a conversar com Gromov, ele transpõe a fronteira: homens normais não se misturam com loucos. Homens racionais não devem conversar com alienados, menos ainda considerá-los interessantes. O que é uma das maiores ironias da novela, pois há um julgamento quase imediato de Ráguin por estar cumprindo o papel de médico pela primeira vez em vinte anos, evidenciando a total deturpação da prática clínica na cidadezinha. A função de Ráguin não era exercer a Medicina de verdade. Simão Bacamarte, por usa vez, não conversa com seus doentes, deixando bem clara a diferença entre ele e os internos.

O médico, como autoridade científica, detém um poder que está acima das suas possibilidades: decidir quem é louco ou não. Simão Bacamarte vacila, tem dúvidas quanto às listas que cria, mas acredita piamente em sua capacidade. Ráguin não tem essa ilusão, ele sabe da sua incapacidade para decidir, está ciente de que o número de pacientes que ele atende todos os dias é bem maior do que o número que deveria atender:

Estou a serviço de uma causa nociva e recebo meu ordenado de gente a que engano; sou desonesto. Mas, na realidade, por mim mesmo não sou nada, apenas uma partícula de um mal social indispensável; todos os funcionários distritais são nocivos e recebem o ordenado em troca de nada... Quer dizer que não sou eu o culpado da minha desonestidade, mas o tempo... Se eu nascesse duzentos anos mais tarde, seria diferente ${ }^{71}$.

Ráguin sabe que é apenas uma peça da engrenagem que faz funcionar e manter tudo como está na sociedade, mas não está disposto a mudar e se exime da culpa, convencendo-se de que não há nada que ele possa fazer.

Não há entrevistas preliminares para adequação do tratamento em nenhuma das duas novelas. No caso da "Enfermaria $n^{\circ}$ 6", o médico é chamado, no geral, pelos vizinhos, que começam a notar algo "diferente", e isso é decisivo para tornar uma pessoa um interno da enfermaria. Portanto, Ráguin não está equivocado quando diz que é apenas parte de um processo em andamento, um títere, ele é apenas a autoridade que valida aquilo que a sociedade e outros acima dele já decidiram.

\footnotetext{
${ }^{71}$ TCHEKHOV, 2007.
} 
Simão Bacamarte também não interroga seus pacientes, observa à distância os moradores e, percebendo que há qualquer "sintoma" parecido com aqueles que constam no manual, desenvolvido por ele mesmo, manda internar a pessoa. Não há explicações, uma vez considerado doente, o médico manda aprisionar o indivíduo, da mesma forma que é feito com os criminosos.

Talvez a similaridade mais importante a ser observada nas duas novelas seja o fato de que uma decisão importante como classificar alguém como louco seja tomada de forma arbitrária. Sendo assim, as duas novelas são mais do que uma crítica ao cientificismo da época, mas profundas análises daquelas sociedades, que permitiam que eventos semelhantes àqueles da ficção acontecessem.

Um discurso é construído pelas autoridades para legitimar a ação de capturar os doentes, e é ele que qualifica as pessoas como loucas ou sãs. O mesmo discurso é rapidamente disseminado, situação em que a própria sociedade passa a exercer o seu poder, identificando quem é louco e ajudando nas denúncias. Foucault chama este fenômeno, em que a própria sociedade faz a manutenção das regras, observando se elas estão sendo cumpridas, em que cada indivíduo torna-se, por vontade própria, um fiscal de si e do outro, de "sociedade disciplinadora" 72 .

Além disso, citando mais uma expressão foucaultiana, estão presentes aí as "relações de poder", em que cada pessoa, ao observar a outra, como uma espécie de "guarda do discurso vigente", garantindo que as regras sejam respeitadas, exerce o seu poder em relação ao outro. E a sociedade é implacável quando se trata de fazer cumprir as regras, não há exceções.

Ao falarmos sobre a construção da Casa Verde, acabamos fazendo um panorama da situação do Brasil na época em que surgiu o primeiro hospício brasileiro. A seguir, faremos um pequeno resumo de alguns eventos importantes da história da Rússia, que ajudam a compreender como era possível a situação em que viviam os internos da "Enfermaria n 6" e $^{\circ}$ mesmo a existência da sinistra cidadezinha, para a qual todos aqueles horrores eram parte do cotidiano.

O tsar Alexandre II foi coroado em 1855, seu antecessor, Nicolau I, havia implantado na Rússia um regime policialesco de delações e condenações terríveis, no qual o medo era o

\footnotetext{
${ }^{72}$ FOUCAULT, Michel. A ordem do discurso. Trad. Laura Fraga de Almeida Sampaio. São Paulo: Loyola, 1996.
} 
principal meio de governar. Portanto, a morte de Nicolau I representava uma esperança de tempos melhores.

Alexandre II governou de 1855 a 1881 e ficou conhecido por suas reformas liberais, como a criação do ziemstvo (administração local) e a organização do sistema judiciário. Foi também durante o seu reinado que o capitalismo começou a se desenvolver na Rússia. Decretou, em 1861, o fim da servidão no país. Em 1881, Alexandre II foi assassinado por membros do grupo "A Vontade do Povo". Foi durante esse reinado que Tchekhov nasceu, em 1860, conhecida como a melhor década desse governo e uma das melhores da história da Rússia $^{73}$.

Com o assassinato de seu pai, subiu ao trono o tsar Alexandre III, que instaurou um novo período de repressão na Rússia, fazendo o país regredir ao Estado Militar que havia antes com Nicolau I.

Alexandre III governou a Rússia de 1881 a 1894, um reinado curto se comparado ao de seu pai. Assim como Nicolau I, Alexandre III disseminou a ideia de que a Rússia deveria ser mais homogênea e menos voltada para o Ocidente. Também ficou conhecido por adotar uma política antissemita, diminuindo as profissões em que judeus podiam atuar e foi em seu reinado que começaram os terríveis Pogroms $^{74}$. Foi neste período que muitos judeus emigraram para os Estados Unidos e outros lugares.

O capitalismo russo desenvolveu-se com mais vigor nessa época. E esse desenvolvimento teve consequências trágicas para o país, o que fez com que a população não aprovasse a implantação do sistema. Em 1891 houve uma crise, na qual milhares de pessoas morreram de fome.

É importante lembrarmos de que a Rússia não viveu as transformações do Renascimento e do Iluminismo. Uma pequena parcela da população era alfabetizada e a Igreja Ortodoxa mantinha o povo na ignorância. Segundo Orlando Figes, o cesaropapismo sempre foi a doutrina oficial da Igreja Ortodoxa ${ }^{75}$.

\footnotetext{
${ }^{73}$ BERMAN, Marshall. Tudo que é sólido desmancha no ar. São Paulo: Companhia das Letras, 2008, pp. 223-68.

${ }^{74}$ Destruição violenta de um grupo - judeus, protestantes, minorias étnicas. Todo o ambiente que torna a vida do grupo possível no lugar é destruído com o intuito de tornar a vida impossível, forçando a imigração daqueles que não morreram durante essas ações.

${ }^{75}$ FIGES, Orlando. A tragédia de um povo: A Revolução Russa 1891-1924. São Paulo: Record, 1999.
} 
O regime tsarista favorecia a corrupção dos funcionários, devido à falta de leis claras, o que deixava os trabalhadores desamparados. E foi nesse ambiente que a industrialização capitalista se desenvolveu.

Essa breve retomada histórica ajuda a entender qual era o clima na Rússia no momento em que Tchekhov escreveu a "Enfermaria $n^{\circ}$ 6". Os russos experimentaram um momento de euforia com o tsar Alexandre II, para, logo depois, assistirem ao retorno do pesadelo do reinado de Nicolau I, que foi o governo de Alexandre III. Nicolau II (1894-1917), filho de Alexandre II, daria continuidade ao despotismo do pai, mantendo uma política de repressão e medo, até a Revolução de 1917.

Tchekhov diz em uma carta enviada a Suvórin, na qual tratava dos preparativos para ir a Sacalina, que "os gloriosos anos 60 não fizeram nada pelos detentos nem pelos enfermos". Ele nota que, em 1890, data da carta, algo começou a ser feito pelos enfermos, mas não pelos detentos ${ }^{76}$.

"Ninguém pode jurar ficar livre da miséria e da prisão" - provérbio russo evocado por Gromov:

Não sabia de nenhuma transgressão que tivesse cometido e era capaz de jurar que também no futuro jamais haveria de matar, incendiar algo ou roubar; mas é acaso difícil cometer um crime sem querer, e não são também possíveis a calúnia ou mesmo um erro judiciário? Não é por acaso que a experiência secular do povo ensina a não jurar que se estará sempre livre da prisão e da sacola do mendigo ${ }^{77}$.

Gromov teme pela sua segurança porque sabe que nem sempre dependerá apenas dele ficar longe da prisão, a Enfermaria $n^{\circ} 6$, que não era um dos seus temores, acabou sendo a sua cadeia, pois afasta e isola o indivíduo exatamente como uma prisão. Seu medo não é infundado, apesar de ser exagerado, o que torna válido o diagnóstico de "mania de perseguição". Gromov representa o medo real do indivíduo que vive na Rússia, como é possível perceber pelo breve resumo feito acima, que inclui um histórico de perseguições, censuras e corrupção.

\footnotetext{
${ }^{76}$ TCHEKHOV, 2002, p. 280.

${ }^{77}$ TCHEKHOV, 2007, p. 190
} 
As irregularidades fazem parte de todas as esferas da vida na cidadezinha: "Na cidade, sabia-se muito bem dessas irregularidades, que eram até exageradas, mas os habitantes encaravam-nas com tranquilidade" ${ }^{78}$.

O médico chega até mesmo a afirmar a Gromov que não existe motivo claro para uma pessoa ser encerrada na enfermaria. É tudo uma questão de casualidade: "Quem foi encerrado tem que ficar aqui e quem não foi está passeando lá fora, eis tudo”.

Gromov retruca dizendo que: "A lei, se não me engano, estabelece claramente que ninguém pode ser privado de liberdade sem julgamento".

E o médico responde: "Quando a sociedade se isola dos criminosos, dos doentes psíquicos e da gente incômoda, em geral, ela é inflexível”.

Portanto, Ráguin, como já foi demonstrado, sabia perfeitamente que era parte de um mecanismo social para livrar a cidade de um incômodo, no entanto, não tinha problema para aceitar essa condição, até com certa naturalidade, desde que ele próprio vivesse bem.

\footnotetext{
Num ano foram enganadas doze mil pessoas; todo o serviço hospitalar baseia-se, como vinte anos atrás, na roubalheira, nos fuxicos e mexericos, no comadrismo, numa charlatanice grosseira, e, como outrora o hospital constitui uma instituição imoral, altamente nociva à saúde dos seus inquilinos. Ele sabe que, atrás das grades da Enfermaria $n^{\circ}$ 6, Nikita espanca os doentes e que Moissieika percorrer diariamente a cidade $^{79}$.
}

O vigia Nikita deixava Moissieika sair para a rua porque ele pedia esmolas e, quando voltava, o vigia tomava todo o dinheiro conseguido.

Em "O Alienista”, tudo leva a crer na bondade de Simão Bacamarte, que permite que os doentes sejam visitados, constrói uma casa bonita para abrigar os doentes, o que eram passos importantes em direção à modernidade na psiquiatria, no entanto, ele vira um ditador. A ironia de Machado de Assis aparece aqui no fenômeno que Roberto Schwarz chamou de "ideias fora do lugar": uma vez que os ideais europeus da nova psiquiatria chegam ao Brasil, ele será adaptado às cores locais, ou seja, de um país periférico, atrasado em vários aspectos em relação à Europa. Em outras palavras, ainda que a psiquiatria moderna, mais humana, mais individualizada, tenha chegado aqui, ela não funcionará da mesma maneira, porque será adaptada ao cenário brasileiro.

\footnotetext{
78 Ibidem, p. 197.

79 Ibidem, p. 207.
} 
Nessa época, era muito urgente para a sociedade do Rio de Janeiro, então capital, construir um hospício para isolar os doentes, que eram um problema social. O magnífico Hospício D. Pedro II é então construído não com o intuito de tratar os doentes de acordo com a psiquiatria surgida com Pinel após a Revolução Francesa, mas como uma medida conveniente para separar os doentes mentais, os mendigos, os paralíticos, os bêbados do restante da sociedade ${ }^{80}$.

A vila de Itaguaí e a Casa Verde são alegorias que podem muito bem representar o Rio de Janeiro e o Hospício D. Pedro II em relação ao mundo. Uma cidade que tem um hospício aos moldes dos franceses, mas que fará tudo funcionar de acordo com uma lógica brasileira. $\mathrm{O}$ Rio de Janeiro era naquela época um lugar que a Europa mal conhecia, um lugar isolado em relação ao mundo, o que fazia da cidade o palco perfeito para que desatinos fossem praticados. "O Alienista" seria uma representação exagerada do Rio de Janeiro de então, e Simão Bacamarte é a caricatura das autoridades da época, um misto de imperador e médico.

Na novela de Tchekhov, os alienados nunca são visitados por ninguém e o clima é bem diferente daquele da novela de Machado de Assis. A Enfermaria $n^{\circ} 6$ tem a mesma função da Casa Verde, no entanto, a forma como os doentes são tratados e a descrição do hospital estão ainda mais distantes da psiquiatria pós-Revolução Francesa.

A descrição do hospital onde fica a Enfermaria $n^{\circ} 6$ se assemelha muito aos hospitais ou asilos da Idade Média, mas há diferenças importantes: há alas separadas de acordo com a enfermidade, há uniforme para os internos e eles não usam grilhões.

Assim como na novela de Tchekhov, nos primeiros asilos da Idade Média, eram internadas aquelas pessoas que não tinham condições financeiras para manterem o próprio sustento, nem família. Essas instituições também recolhiam delinquentes, todos ficavam juntos no mesmo ambiente e o tratamento era o mesmo para todos, forte vigilância e açoites ao menor sinal de perturbação da ordem, da mesma maneira que o guarda Nikita fazia.

As descrições dos doentes não fazem referência ao que há de humano neles. Um dos pacientes, o mujique, é descrito como um “animal imóvel, guloso e nada asseado, que já perdera havia muito a capacidade de pensar e sentir".

\footnotetext{
${ }^{80}$ ANTUNES, 2002, pp. 81-105.
} 
O primeiro "come e bebe maquinalmente, quando servem". O segundo tem movimentos lestos, assobia, é Moissieika. O terceiro é Gromov, que tem "mania de perseguição" e anda de um lado a outro, é o único que tem sua moléstia denominada. Ele é descrito com mais detalhes, e há uma nota sentimental ao descrevê-lo, marcada pela presença do diminutivo, ele fecha o seu "roupãozinho" (халатик). Ele é o único que tem feições humanas: "Quando fala, você reconhece nele o louco e, ao mesmo tempo, a pessoa humana",

As descrições demonstram como o paciente deixa de ser um ser humano, com características individuais; após a internação ele é um doente mental, ou simplesmente um louco, tem sua identidade aniquilada para aderir a outra, a loucura, mesmo que contra a sua vontade. O narrador tchekhoviano descreve os pacientes ressaltando suas características animalescas porque o conjunto de aspectos que tornava cada interno um ser humano, são, pouco a pouco, apagados pelo tratamento dado a eles. A condição de ser humano passa a ser negada a eles assim que passam pela porta da Enfermaria $n^{\circ} 6$.

No começo da paranoia de Gromov, ele faz o seguinte comentário a respeito das pessoas que lidam com o sofrimento alheio todos os dias:

As pessoas que têm uma relação oficial e profissional com o sofrimento alheio, por exemplo, juízes, policiais, médicos, com o correr do tempo, por força do hábito, ficam a tal ponto curtidas que, mesmo querendo, só podem tratar os seus clientes de maneira formal; por esse aspecto, não se distinguem em nada do mujique que mata carneiros e bezerros num fundo de quintal e não repara sequer no sangue ${ }^{82}$.

Ele compara as vítimas desses profissionais aos animais abatidos, são maltratados da mesma maneira e deixam de ser um ser humano com uma história particular. Com anos e anos fazendo a mesma coisa, vão tornando-se insensíveis aos sofrimentos do outro. O médico aparece na comparação acima como mujique, ou seja, a instrução que ele tanto admira e que ele crê que o separa dos demais, não faz dele uma pessoa melhor, com sentimentos nobres e preocupações para com os outros seres humanos.

Como já foi dito, na novela de Tchekhov, tudo corrobora para uma crescente sensação de angústia, inclusive a imprecisão, não sabemos que cidade é essa, nem em que ano estamos, até o capítulo V, que revela que Ráguin terminou o ginásio de 1863 e depois, no capítulo VIII,

\footnotetext{
${ }^{81}$ TCHEKHOV, 2007, p. 187.

82 TCHEKHOV, 2007, p. 190.
} 
temos outra data, para demonstrar a falta de cultura do médico Ievguêni Fiódoritch Khóbotov, que é designado para auxiliar Ráguin no hospital, o narrador diz que ele tem apenas um único livro: As mais recentes receitas da clínica vienense, no ano de 1881. Sabemos, portanto, que os acontecimentos se passam nesse ano ou um pouco depois, o que é uma informação chave para a narrativa.

A revelação das datas, a proximidade do século XX, tem para o leitor de hoje um peso certamente maior do que tinha na época de lançamento da novela, pois parece inadmissível que tal situação fosse possível àquela altura da História. A novela de Tchekhov está localizada poucos anos antes de sua publicação, em 1892. Machado de Assis, ao contrário, localizou sua novela em algum ponto após a Revolução Francesa, mas no Brasil Colônia, portanto, num passado distante, de modo que a semelhança com os acontecimentos contemporâneos deve ter impressionado o seu leitor de 1882.

Tchekhov não deu nome à cidadezinha e Machado de Assis tomou emprestado o nome de uma vila, que tem uma história cercada de mitos, que não podem ser verificados. Os dois lugares são alegorias de qualquer lugar na Rússia e no Brasil. O que faz o leitor duvidar sempre dos fatos narrados, eles vão ficando cada vez mais absurdos, parecem cada vez mais irreais. O ápice dessa desconfiança acontece quando o leitor faz a seguinte pergunta: Quem é de fato louco?

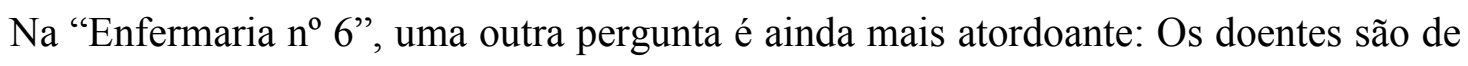
fato loucos e por isso foram internados ou foram internados e por isso ficaram loucos?

Os acontecimentos narrados conduzem o leitor até essas duas perguntas. Não sabemos a resposta para nenhuma delas, mas temos conhecimento de que as condições oferecidas aos internos da Enfermaria ${ }^{\circ} 6$ e, mesmo de todo o hospital, propiciam o pleno desenvolvimento da loucura e não da cura.

Nenhum processo dentro da novela parece justo, todos aconteceram arbitrariamente. Ráguin não se importa com os fatos, ele mesmo internou todos os pacientes da enfermaria, a sua reação é sempre conformar-se, ignorando tudo aquilo que está à sua volta. Até mesmo quando ele é trancafiado na enfermaria, a princípio, não tem reação, diz: “Tanto faz...". Mas logo se sente incomodado. Vítima do sistema do qual fez parte durante vinte anos, sentiu a amargura de ser julgado e condenado, sem a possibilidade de recorrer, sem nem mesmo entender como isso aconteceu. 
Os habitantes da cidadezinha acreditam naquilo que é decidido pelas autoridades, sem questionamento. Quando algo estranho acontece, logo é aceito, sem alteração do cotidiano.

Gromov é levado para o hospital porque não tinha família, primeiro fica na ala de doenças venéreas, depois é transferido para a Enfermaria $n^{\circ} 6$. Nenhum remédio real é oferecido para nenhum dos internos. O médico não conversa com os doentes, apenas lhes prescreve placebo. A vida de Gromov é minuciosamente descrita para que tenhamos uma ideia de como acontece o processo de internação. Ele é o único que tem toda a história contada, porque seria redundante contar a história de cada um dos pacientes. Todas as internações aconteceram de maneira semelhante.

Em "O Alienista”, a única história bem contada é a de Simão Bacamarte, protagonista absoluto da novela, e todos os outros personagens existem em função dele. Portanto, não há grandes detalhes sobre nenhum dos pacientes. Mas sabemos do método utilizado por Bacamarte para selecionar os possíveis pacientes. Ele observava o comportamento das pessoas e decide quem é louco e quem não é. A certa altura da novela, as pessoas começam até a temer o olhar do médico, pois sabem que estão sendo analisadas.

Há diferença no processo de internação nas duas novelas, na "Enfermaria $n^{\circ}$ 6" os moradores da cidadezinha observam uns aos outros e a delação parte deles, é assim que o médico fica sabendo onde buscar o possível doente, vai ao seu encontro e, ao verificar que a pessoa não tem condições de cuidar de si, decide interná-la no hospital. Em "O Alienista”, ao contrário, toda a ação é pensada e executada pelo próprio Bacamarte, e, na maioria das vezes, os moradores até discordam do médico, não entendem por qual motivo algumas pessoas foram internadas se, aos olhos da população, eram completamente "normais".

A implantação da psiquiatria no Brasil se deu nos moldes da europeia, já segundo os preceitos surgidos após Revolução Francesa, humana, individual e racional, encarando a loucura como uma doença. Como já dissemos, coube à figura do alienista a responsabilidade de implantar a psiquiatria seguindo o modelo europeu.

O aumento da população brasileira, sobretudo do Rio de Janeiro, que era a capital do país, pedia que uma medida fosse tomada para administrar a loucura e os loucos. Foi nesse contexto que surgiu o primeiro hospício brasileiro, em 1841. Temos em "O Alienista" um pequeno retrato do Brasil do século XIX, no que diz respeito à situação do louco e ao tratamento da loucura. 
Em "O Alienista", curiosamente, o final é igual ao da "Enfermaria no 6", o médico, Simão Bacamarte, acaba internado no hospício. No entanto, a maneira como ele foi parar ali é bem diferente das circunstâncias em que Ráguin acabou na Enfermaria nº 6.

Os supostos doentes vão parar na Enfermaria $n^{\circ} 6$ ou na Casa Verde porque foi decidido que eram loucos, a decisão é feita baseada numa convenção social. A loucura, que deveria ser um assunto apenas da Medicina, ou principalmente dela, é então, nessa época, uma questão social, como já vimos. Em "O Alienista”, Machado de Assis ironiza a fé desmedida na figura do médico, que se sustenta pelo que ele "diz" e não pelo que ele faz. Sua aparência imponente, combinada à sua autoconfiança, faz com que as pessoas acreditem nele.

$\mathrm{Na}$ "Enfermaria no 6", o arbitrário é estabelecido de uma maneira apavorante, como se todos os elementos - os moradores, as autoridades - fossem se articulando em uma teia até prender o sujeito. Na novela de Machado de Assis, a forma como as pessoas são internadas não deixa de ser assustadora, até pelo despotismo de Bacamarte, mas o tom irônico e como tudo é contado, como se fosse uma crônica, dá uma estranha leveza aos acontecimentos. Em ambas as novelas, a internação faz parte do cotidiano da população, porém o exagero causa desconfiança nos moradores de Itaguaí, o que nunca ocorre na cidadezinha.

A arbitrariedade em "O Alienista" tem como fonte a figura do médico, Simão Bacamarte, que exerce seu poder de forma opressora, é um tirano, que não aceita conselhos de ninguém, o que fica mascarado pela sua imagem refinada e personalidade calma, que o fazem parecer fonte infinita de bondade. Ele não ouve nem mesmo seu grande amigo, o boticário.

Boris Schnaiderman lembra que: "a fé cega de Simão Bacamarte, que decide os destinos da população de Itaguaí, lembra os desatinos do nazismo, inclusive os experimentos de Mengele com seres humanos" ${ }^{, 83}$.

Em sua volumosa correspondência, Tchekhov abordou muitas vezes a questão da Medicina na época, que tinha uma tendência a ser positivista e é comum atribuir a Tchekhov um viés também positivista. O próprio autor esclarece a confusão em uma de suas cartas em que diz que o seu caráter positivista vem da sua experiência de vida, sendo neto de um servo da gleba alforriado, e também de sua prática médica, e não de leituras ou ideias. Em carta a

\footnotetext{
${ }^{83}$ Schnaiderman, Boris. "'O Alienista', um conto dostoievskiano?” Teresa: revista de literatura brasileira / Programa de Pós-graduação da Área de Literatura Brasileira. Departamento de Letras Clássicas e Vernáculas. Faculdade de Filosofia, Letras e Ciências Humanas. Universidade de São Paulo. São Paulo: Ed. 34: Imprensa Oficial, 2006.
} 
Suvórin, Tchekhov declarou que, na Medicina russa, Bótkin tinha o mesmo valor que Turguiêniev, do ponto de vista do talento, e Zakhárin estava no mesmo patamar que Tolstói, citando assim ao menos duas de suas referências no campo da Medicina. ${ }^{84}$

Dal-Ri Peres cita em seu trabalho o crítico soviético V. B. Katáiev, que notou similaridade entre o método científico de Zakhárin e a obra de Tchekhov. A ligação está no princípio da "individualização".

Zakhárin, segundo Katáiev, desenvolveu um método para superar as dificuldades que os médicos encontravam, principalmente na área da Terapêutica. Mas ele localizou as causas das imperfeições do tratamento 'no plano teórico de estudo e diagnóstico da doença' e não apenas nos 'métodos práticos de seguimento e tratamento'. Seu método baseia-se na rigorosa 'individualização' de cada caso e na recusa categórica do 'padrão, do clichê no tratamento'. Assim, a base do tratamento não pode ser a 'doença', como se ela fosse única para todos, mas o 'doente', com todas suas particularidades próprias, únicas'. ${ }^{85}$

Trata-se, portanto, de uma proposta de terapia individualizada, para a qual o interrogatório constitui a parte mais importante para a formulação do diagnóstico. Estão já aí no "método científico da escola de Zakhárin" alguns preceitos que seriam melhor desenvolvidos pela psiquiatria, como a individualização, a consideração de todos os fatores subjetivos.

É possível verificar os preceitos do método de Zakhárin no padrão de Medicina que Tchekhov considerava o mais eficiente e justo. O médico de "Uma história enfadonha" fala da importância do tratamento individualizado. Gromov também não se satisfaz com as respostas de Ráguin, que oferece apenas justificativas generalizantes.

\subsubsection{Antipsiquiatria}

As décadas de 1950 e 1960 passaram por verdadeiras revoluções do ponto de vista dos valores da sociedade. Uma série de movimentos juvenis ocorreu principalmente na Europa e nos Estados Unidos: a Geração Beat, os Hippies, Maio de 68, entre outros. Esses jovens questionavam os valores vigentes na cultura ocidental: a religião, a família, o consumismo, o

\footnotetext{
${ }^{84}$ Idem, p. 226.

${ }^{85}$ KATÁIEV apud PERES, 146.
} 
otimismo dos Estados Unidos após a Segunda Guerra Mundial, o comunismo, o nacionalismo etc. O conjunto desses movimentos ficou conhecido como Contracultura.

A Contracultura logo se espalhou pelo mundo através dos meios de comunicação em massa, era a primeira vez que manifestações eram disseminadas dessa forma. Foi um movimento estritamente cultural, que não fazia uso de violência, o que também era uma novidade.

Dentro dessa série de contestações surgidas nesse período, começou a ganhar força o movimento que ficaria conhecido como Antipsiquiatria. Os médicos que começaram esse movimento questionavam as teorias e práticas fundamentais da psiquiatria tradicional. Eram contra: o afastamento do doente do convívio em sociedade, o tratamento contra a vontade do paciente, a separação corpo e mente, a indiferença diante dos sentimentos do paciente, a falta de ética, o uso de diagnóstico baseado em manuais, a estigmatização do paciente, a semelhança dos hospitais psiquiátricos com prisões etc.

Os filósofos Michel Foucault e Gilles Deleuze juntaram-se ao grupo que criticava o poder e o papel da psiquiatria na sociedade. Foucault considerava os conceitos de sanidade e loucura construções sociais, indicativas do poder dos "normais" sobre os "doentes".

Como represália, alguns dos participantes dos movimentos da contracultura foram classificados como loucos e acabaram internados em instituições psiquiátricas. As autoridades queriam então "fabricar" a loucura onde ela não existia. O movimento antipsiquiátrico ganhou força após essas internações, que demonstravam mais uma vez que a psiquiatria ainda estava sendo usada como instrumento disciplinar da sociedade.

Os jovens representantes de minorias - negros, homossexuais e mulheres - eram presos, perseguidos, exilados, mas, principalmente nos Estados Unidos, eles foram classificados como loucos e acabaram trancafiados em asilos e hospitais psiquiátricos, garantindo assim exclusão deles da sociedade. Nesse período, em diversos lugares do mundo, inclusive na América Latina, ocorreu uma série de internações por motivos que não tinham ligação com a loucura.

O movimento antipsiquiátrico era encabeçado por alguns psiquiatras que, a princípio, não estavam envolvidos nos movimentos da Contracultura, como David Cooper, David Laing e Gregory Bateson, que eram fortemente influenciados por ideais da esquerda. Eles 
começaram a questionar a psiquiatria, sua função na sociedade, seus meios. O principal ponto defendido por esses médicos é que a loucura é algo fabricado pelas relações de poder.

A antipsiquiatria propunha também o fechamento das instituições médicas psiquiátricas alegando que as práticas adotadas por esses estabelecimentos faziam uso constante de uma violência desumana. Consideravam errônea a própria denominação "doença mental".

A antipsiquiatria acredita que os tratamentos psiquiátricos tradicionais atendem a interesses políticos e econômicos bastante claros, considerando a natureza política da ciência psiquiátrica, que anula o indivíduo em nome da ordem e do bom exercício do poder. A psiquiatria a que ela se opõe pune com o encarceramento os indivíduos considerados improdutivos e perigosos para o sistema capitalista ${ }^{86}$.

A citação acima resume alguns dos temas de "Enfermaria $n^{\circ}$ 6", na conversa que Ráguin tem com Gromov, ele diz:

O melhor na sua condição seria fugir daqui. Mas, infelizmente, é inútil. Será apanhado. Quando a sociedade se isola dos criminosos, dos doentes psíquicos e da gente incômoda em geral, ela é inflexível.” (...) "Se existem prisões e manicômios, alguém deve ficar neles. Se não for o senhor, serei eu, se não eu, algum terceiro. Espere, quando, num futuro distante, tiverem terminado sua existência as prisões e os manicômios, não existirão grades nas janelas, nem roupões de internados. Está claro que essa época chegará cedo ou tarde ${ }^{87}$.

O que diz Ráguin sobre o papel do hospício na sociedade se assemelha muito às críticas feitas pelos movimentos antipsiquiátricos. Tchekhov coloca essas palavras na boca de seu personagem num momento em que os doentes mentais tinham acabado de ser reconhecidos como doentes. Ainda faltavam muitos anos para que as discussões a respeito do fim dos manicômios começassem, como Tchekhov propõe em sua novela.

Na novela machadiana, os moradores de Itaguaí reúnem-se para colocar abaixo a Casa Verde e destronar Simão Bacamarte, no entanto, como numa farsa, a Revolta dos Canjicas se revelará um movimento frágil e desorganizado. O procedimento de Machado de Assis é bem diferente daquele de Tchekhov, ao construir a revolta, ele propõe a destruição dos hospícios e dos alienistas como são, mas volta atrás, restabelecendo a situação inicial da narrativa, porém,

\footnotetext{
${ }^{86}$ OLIVEIRA, William V. de. "A fabricação da loucura: contracultura e antipsiquiatria." In: Revista História, Ciência, Saúde-Manguinhos, vol. 18. n. 1. Rio de Janeiro, março de 2011.

${ }^{87}$ TCHEKHOV, 2007, p. 212.
} 
o que foi dito está dito, não pode ser apagado. O tom irônico e fantasioso da narrativa, que é uma reunião de pequenas crônicas, retira o peso daquilo que foi dito.

\subsubsection{Psiquiatria hoje}

Em 14 de fevereiro deste ano, os psiquiatras Dr. Savenko e Dr. Perekhov, membros da Associação Psiquiátrica Independente da Rússia, publicaram um artigo no site da Psychiatric Times, intitulado "The State of Psychiatry in Russia"88 (O Estado da Psiquiatria na Rússia). Nesse artigo, eles falam da situação da psiquiatria na Rússia neste momento em que, mesmo após a lei de 1992, que tornou obrigatória a assistência psiquiátrica e garantiu os direitos dos cidadãos, o cenário não foi modificado.

Não está prevista qualquer punição para o descumprimento da Lei de Assistência Psiquiátrica de 1992. Até hoje, 90\% dos pacientes psiquiátricos internados não recebem informações precisas sobre o seu diagnóstico ou tratamento, nem têm acesso aos próprios registros médicos e são, muitas vezes, internados involuntariamente.

Os pacientes ainda são vistos como um incômodo e um perigo pela sociedade. $\mathrm{O}$ número de psiquiatras é pequeno, o que faz com que eles tenham que trabalhar mais horas, e também é difícil conseguir fármacos cedidos pelo Estado. Desde 2000, um terço das instituições psiquiátricas foi considerado impróprio devido à insalubridade.

"As condições de vida são frequentemente inadequadas e, às vezes, até macabras: convivem de 12 a 15 pacientes em uma grande sala, não há mesas de cabeceira, nem banheiros suficientes, muitas vezes, nem divisória e há grades nas janelas.” Essa descrição que o médico faz se assemelha terrivelmente à descrição feita pelo narrador da "Enfermaria $\mathrm{n}^{\mathrm{o}}$ 6" no início da novela. Já se passaram 124 anos da primeira publicação da novela de Tchekhov. Ráguin achava que a situação melhoraria 200 anos mais tarde, não exagerou.

No Brasil, a situação do doente mental até a década de 1970 era absurda, é só no final dessa década que tem início o movimento que ficou conhecido como Reforma Psiquiátrica. $\mathrm{O}$ objetivo desse movimento era lutar pelos direitos dos pacientes psiquiátricos do país. A

\footnotetext{
${ }^{88}$ http://www.psychiatrictimes.com/special-reports/state-psychiatry-russia/page/0/1
} 
Reforma dividiu-se em duas fases: a primeira de 1978 a 1991, que criticava principalmente o modelo de internação, e a segunda a partir de 1992 até os dias atuais ${ }^{89}$.

Após o final da Segunda Guerra Mundial, surge o modelo manicomial brasileiro, composto de instituições em sua maioria privadas. Nos anos 1960, é criado o Instituto Nacional de Previdência Social (INPS) e o Estado passa a utilizar os serviços psiquiátricos do setor privado. A loucura passou a ser então um negócio para os manicômios.

O movimento Antipsiquiátrico influenciou diretamente nos questionamentos dos profissionais que trabalhavam nas instituições psiquiátricas brasileiras, defendendo a reintegração do doente à sociedade, o convívio familiar, evitando as internações, e oferecendo tratamento de qualidade aos pacientes internados, a desinstitucionalização do doente mental e a humanização do tratamento.

A I Conferência Nacional de Saúde Mental aconteceu apenas em 1987, que recomendou às instituições que fizessem mais investimentos nos serviços extra-hospitalares e uma integração entre profissionais de outras áreas com a psiquiatria, defendendo então um modelo que retira o doente do hospital. O II Congresso Nacional do MTSM foi realizado no final de 1987 e teve como principal pauta o Movimento de Luta Antimanicomial, que se consolidou ali.

Em 1989, um ano após a criação do Sistema Único de Saúde (SUS), o deputado Paulo Delgado (PT/MG) deu entrada no Congresso de um Projeto de Lei no qual propõe a regulamentação dos direitos da pessoa com transtornos mentais e a extinção progressiva dos hospícios no Brasil. Mas a lei é aprovada apenas em 2001.

A Lei Federal 10.216/2001 privilegia o tratamento em bases comunitárias e dispõe sobre a proteção e os direitos das pessoas com transtornos mentais, mas não estabelece de maneira clara como será feita a progressiva extinção dos manicômios. A partir daí, são criados os Centros de Atendimento Psicossocial e os Centros de Convivência e Cultura, o que contribuiu para a desinstitucionalização da loucura.

Comparativamente, tendo em vista os dois panoramas acima, a situação da psiquiatria no Brasil mudou muito, no entanto, as mudanças são recentes, e ainda há relatos de pessoas abandonadas, que são mantidas em alas psiquiátricas após terem recebido alta. Já na Rússia, o

\footnotetext{
${ }^{89}$ AMARANTE, P. D. de C. Loucos pela vida: a trajetória da reforma psiquiátrica no Brasil. Rio de Janeiro: Fiocruz, 1995.
} 
cenário desenhado pelo relatório dos psiquiatras Dr. Savenko e Dr. Perekhov ainda revela uma situação para os doentes mentais que está mais próxima da Idade Média do que do século XXI.

\subsection{Bacamarte e Ráguin ${ }^{90}$}

Simão Bacamarte é o protagonista de "O Alienista". O narrador conta a história de Simão como se ele fosse uma lenda local: “As crônicas da vila de Itaguaí dizem que em tempos remotos vivera ali um certo médico $(\ldots)^{91 "}$.

Bacamarte é filho de nobres e é o maior médico do Brasil, de Portugal e das Espanhas. Estudou em Coimbra e Pádua, regressou ao Brasil aos 34 anos, ignorando as súplicas do próprio rei de Portugal, que desejava que Simão permanecesse em Coimbra ou em Lisboa, como reitor da universidade: “A ciência, disse ele a Sua Majestade, é o meu emprego único; Itaguaí é o meu universo ${ }^{92}$ ".

Os dados acima estão no primeiro parágrafo da novela, deixando claro desde o início o que podemos esperar do alienista, que é um homem que vive para a ciência e que tem, como se diria popularmente, "mania de grandeza".

Aos 40 anos, casou-se com D. Evarista da Costa e Mascarenhas, que não lhe deu filhos. A princípio, Simão era um médico geral, logo resolveu especializar-se nas patologias cerebrais, isso porque não havia na colônia e nem no reino autoridade na matéria, sendo assim pensou que poderia trazer fama para si, para o Brasil e para Portugal. Guardava seus arroubos de grandeza para a intimidade, "exteriormente era modesto".

\footnotetext{
${ }^{90}$ Andréi e Simão Bacamarte têm nomes importantes para o cristianismo. Simão é um nome de origem hebraica que quer dizer aquele que ouve. Na Bíblia, é o nome de alguns personagens, sendo que o mais famoso é Simão, o apóstolo que recebeu de Jesus o nome de Pedro. O apóstolo foi o primeiro Papa da Igreja Católica. Jesus teria dito que Pedro era a pedra sobre a qual construiria toda a sua igreja. A ironia é que Simão não ouve ninguém. Machado de Assis já havia utilizado o nome Simão em outro conto, "Frei Simão", publicado no livro Contos Fluminenses de 1870, que conta a história de um frei que enlouquecera depois de descobrir que foi enganado pela família. Um dado importante é que o nome, também nesse caso, está relacionado ao tema da loucura. Por coincidência, André (Andréi em russo) é o nome do irmão de Pedro, segundo a Bíblia, e é ele o fundador da igreja do Bizâncio (Constantinopla) em 38 d. C. Andréi é um nome de origem grega e quer dizer aquele que tem coragem ou hombridade. Os apóstolos Pedro e André eram pescadores e foram chamados por Jesus para serem "pescadores de homens". Pedro é o santo mais importante da tradição católica, enquanto André é o mais eminente para a Igreja Ortodoxa. Ainda que seja para outros objetivos, Andréi lefiemítch e Simão Bacamarte não deixam de ser pescadores de homens.

${ }^{91}$ ASSIS, 2011, p. 38.

${ }^{92}$ Ibidem.
} 
Bacamarte era conhecido na cidade por ser muito paciente, tinha sua vida toda voltada para a ciência, não comia nem dormia direito, não dava atenção à mulher. Era simpático com as pessoas, oferecia jantares, e confiava no vigário e em Crispim Soares, o boticário, seu grande amigo.

Simão Bacamarte é sempre comparado a grandes figuras históricas, por ocasião do retorno de D. Evarista do Rio de Janeiro, chamaram-na de "esposa do novo Hipócrates", o mais famoso médico da Antiguidade. O grego Hipócrates (460 a. C. - 370 a. C.) é considerado o pai da Medicina. Quando os moradores de Itaguaí se cansam dos desmandos de Simão, comparam-no a Golias, o gigante filisteu, que foi derrotado por Davi, libertando Israel dos filisteus.

O narrador descreve sempre Bacamarte como sendo grandioso. Os moradores, apesar de desconfiarem da sanidade do médico, também têm muito respeito por ele. Mas talvez uma das características mais marcantes do médico é que ele próprio tem certeza da sua grandiosidade.

Por ocasião da Revolta dos Canjicas, quando os rebeldes chegam até a casa do alienista para cobrar explicações, ele responde:

\footnotetext{
Meus senhores, a ciência é coisa série, e merece ser tratada com seriedade. Não dou razão dos meus atos de alienista a ninguém, salvo aos mestres e a Deus. Se quereis emendar a administração da Casa Verde, estou pronto a ouvir-vos; mas se exigis que me negue a mim mesmo, não ganhareis nada. Poderia convidar alguns de vós, em comissão dos outros a vir ver comigo os loucos reclusos; mas não o faço, porque seria dar-vos razão do meu sistema, o que não farei a leigos, nem a rebeldes ${ }^{93}$.
}

Disse isso tudo com a mesma serenidade de sempre, com a certeza de quem sabe que tem poder suficiente para fazer tudo da maneira como achar melhor. Acima dele só estão os mestres mortos, que lhe servem de inspiração, e Deus. Portanto, Simão e sua ciência estão acima do povo de Itaguaí, que é seu laboratório. Só aceitaria críticas e emendas de outro homem de ciência, e só ressalta isso porque sabe que não há outro em toda Itaguaí.

A calma característica de Simão deixa a população desarmada em sua presença. As pessoas não têm coragem de agir contra o médico, o que demonstra mais um aspecto do

\footnotetext{
${ }^{93}$ ASSIS, 2011, p. 71.
} 
caráter despótico de Simão. Não são raros os exemplos históricos de déspotas que conquistaram a simpatia de seu povo com gestos moderados.

O narrador, a certa altura da novela, chama Simão de grande homem, com austera fisionomia, impassível como um "deus de pedra". Demonstrando que a calma de Simão não era derivada da bondade dos seus atos, mas de sua indiferença.

Após o fim da revolta e o restabelecimento da Câmara de Vereadores, o poder do médico só cresceu, o absurdo atingiu o seu mais alto patamar. Bacamarte mandava prender na Casa Verde qualquer pessoa, começou a inventar moléstias que não faziam sentido, parecendo ele mesmo louco. "Tudo era loucura." Inventou uma lei que previa que toda pessoa que declarasse ter duas ou três onças de sangue godo deveria usar um anel de prata no dedo polegar da mão esquerda. Todos com anel foram internados.

Foi nesse ponto que decidiu internar a própria esposa, que passava horas admirando seus vestidos e joias. Bacamarte disse que ela sofria de "mania sumptuária", um tipo de demência, uma clara crítica do autor à crescente sociedade consumidora do Rio de Janeiro. Foi assim que Simão voltou a cair nas graças dos moradores de Itaguaí, que acreditaram na sua ciência, na sua bondade, pois, se ele teve coragem de recolher à Casa Verde a própria esposa em nome da ciência, só poderia ser sincero.

Quando toda a vila achava que Bacamarte tinha feito todos os desmandos possíveis, ele decidiu soltar todos que estavam na Casa Verde e prender os que estavam livres.

Quanto à descrição física de Simão Bacamarte:

Um amplo chambre de damasco, preso à cintura por um cordão de seda, com borlas de ouro (presente de uma Universidade) envolvia o corpo majestoso e austero do ilustre alienista. A cabeleira cobria-lhe uma extensa e nobre calva adquirida nas cogitações quotidianas da ciência. Os pés, não delgados e femininos, não graúdos e mariolas, mas proporcionados ao vulto, eram resguardados por um par de sapatos cujas fivelas não passavam de simples e modesto latão. Vede a diferença: - só se lhe notava luxo naquilo que era de origem científica; o que propriamente vinha dele trazia a cor da moderação e da singeleza, virtudes tão ajustadas à pessoa de um sábio ${ }^{94}$.

Durante toda a novela, o narrador se esforça para apresentar um Simão simples, não alterado pela grandeza de seus feitos e da sua alma. Um homem sábio e modesto. No entanto,

\footnotetext{
${ }^{94}$ ASSIS, 2011, p. 96.
} 
ele é sempre descrito como um deus ou um rei, dotado de qualidades quase extraterrenas, que os humildes não entendem, só podem admirar. Assim como Jesus ou Maomé, ele está ciente do seu poder, mas prefere sempre a moderação.

No auge do seu poder e da sua confusão, Simão Bacamarte chega à conclusão de que não há loucos em Itaguaí, tinha se enganado. Então, repassando a sua tese, de que os doentes são aqueles com "perfeito equilíbrio mental e moral", que possuem "sagacidade, paciência, perseverança, tolerância, veracidade, vigor moral, lealdade", conclui que ele é o único cidadão perfeito de Itaguaí, portanto, o único louco. Reúne um conselho de amigos que confirma a sua perfeição.

O protagonista da "Enfermaria n $n^{\circ}$ " é Andréi Iefímitch Ráguin, no tempo da narrativa deve ter em torno de 50 anos, pois terminou o ginásio em 1863, depois cursou a universidade e já é diretor do hospital há 20 anos. O pai era "doutor em Medicina e cirurgião" e queria que o filho também fosse.

Ráguin queria ser pope, era então muito religioso, o que o pai achou muito engraçado e disse que deserdaria o próprio filho se ele fizesse essa escolha, assim ele se tornou médico, por decisão do pai autoritário. Aparece aqui o primeiro sinal que será a marca de Ráguin durante toda a sua vida, a falta de vontade para tomar decisões.

Andréi Iefímitch nunca sentiu que tinha vocação para a Medicina, preferia História e Filosofia. Ele nunca se casou, leva uma vida de monge. Talvez seus únicos gostos verdadeiros sejam a leitura e a bebida. Não é sociável, apesar de ser muito cortês, evita o convívio com as pessoas, sendo a única exceção o chefe dos Correios, Mikhail Avierânitch. Ráguin é muito inteligente, desenvolve raciocínios elaborados ao longo da novela, sobretudo em suas conversas com Gromov.

A principal característica de Ráguin é a sua passividade, não discorda de nada, apesar de ver com muita clareza a corrupção e o descaso à sua volta.

Andréi Iefímitch ama extraordinariamente a inteligência e a honestidade, mas faltam-lhe caráter e fé no seu direito, para organizar junto a si uma vida inteligente honesta. Decididamente, não sabe ordenar, proibir e insistir. É como se tivesse feito a si mesmo a promessa de não elevar jamais a voz e não empregar o modo imperativo. Para ele, é difícil dizer "me dê" ou "traga"; quando quer comer, tosse indeciso e diz à cozinheira: "Eu gostaria de tomar chá...” ou "Eu gostaria de jantar". Está absolutamente acima das suas forças dizer ao vigia que deixe de roubar, enxotá-lo ou suprimir de vez esse cargo inútil, parasitário. Quando 
enganam Andréi Iefímitch, ou adulam-no, ou dão-lhe para assinar uma fatura reconhecidamente falsa, ele cora como uma lagosta e sente-se culpado, mas assim mesmo assina a fatura; quando os doentes queixam-se da fome ou das enfermeiras rudes, ele fica encabulado e balbucia com de culpado:

- Está bem, está bem, vou verificar isso depois... Deve ser algum mal-entendido... ${ }^{95}$

O trecho acima resume bem a personalidade de Ráguin, essa inação estará presente em todos os âmbitos de sua vida, tornando-o incapaz de mudar o seu entorno e a si mesmo. Ráguin é muito gentil, educado, e toda a sua descrição nos leva à conclusão de que é um sujeito extremamente delicado, até sua voz é fina. No entanto, sua aparência é o oposto disso, o narrador compara Ráguin a um mujique.

Ráguin é um homem forte, "enorme" nas palavras do narrador, de aparência rude, tem barba, rosto forte, é glutão, desajeitado. Ele tem nariz vermelho e rosto coberto de veias azuis, eufemismos para definir um alcoólatra. Usa camisas macias, de linho ou algodão porque tem um inchaço no pescoço, "não se veste como médico". Chega a usar por dez anos a mesma roupa, mas mesmo as roupas novas, nele, parecem velhas. Além disso, ele usa a mesma roupa para atender os doentes e em sua casa. Enfim, ele tem uma aparência desagradável e descuidada, que destoa desconcertantemente do que era esperado para um diretor de hospital, mas que está de acordo com a sua personalidade, pois a falta de vontade se reflete inclusive no seu modo de vestir-se. Ele não se importa com a aparência, todas as qualidades de Ráguin são interiores, ele é um sujeito introspectivo, voltado para si.

A introspecção de Ráguin pode, num primeiro momento, soar como arrogância, mas tendo em vista toda a sua descrição - psicológica e física - sabemos que não é esse o caso, trata-se de uma inaptidão. Ráguin tem uma dificuldade extrema de se relacionar com as outras pessoas, não sabe como fazê-lo. É o oposto de Simão Bacamarte, enquanto ele é cheio de hesitações, o alienista tem certezas. Simão é quase um Deus, enquanto Ráguin é um ser humano comum, um pouco do que hoje chamaríamos de "perdedor". Ráguin não é um herói, e nunca pretendera ser, ao contrário de Simão, que queria ser o fundador da psiquiatria em Portugal e no Brasil.

Bacamarte apresenta a mesma dificuldade de Ráguin em compreender o outro, o que gera a impossibilidade de comunicar-se com ele, mas o médico de Itaguaí não pretende entender as pessoas, até mesmo porque ele se vê acima dos outros, já Ráguin parece não estar

\footnotetext{
${ }^{95}$ TCHEKHOV, 2007, p. 198.
} 
apto para isso, não por orgulho, mas por incapacidade. Para ambos, a obsessão pela ciência, de formas diferentes, representa um impedimento para sair de si e ir em direção ao outro, o que é curioso, porque a Medicina deveria, em tese, ser uma profissão praticada por indivíduos que fazem naturalmente esse movimento. No entanto, Machado de Assis e Tchekhov estão demonstrando o mesmo fenômeno, a preocupação dos médicos de entender cientificamente as doenças e o que se passa com o sujeito faz com que eles se esqueçam de olhar o sujeito como um ser humano completo, ignorando todos os aspectos individualizantes.

Quando o alienista muda sua lista de sintomas e diagnósticos, mandando soltar os internos para prender aqueles que estavam livres, demonstra desespero. Pois, pela lógica, os loucos devem ser minoria. Se mais da metade da cidade está internada, a teoria de Bacamarte só pode ser falha, é então que ele inverte a classificação, mandando capturar a minoria. Se antes todos os desvios de caráter são considerados loucuras, agora os corretos serão presos. $\mathrm{O}$ que demonstra a impossibilidade de Bacamarte estabelecer uma regra.

Em nenhum momento, o alienista fala sobre os seres humanos e seus sofrimentos, está preocupado apenas em estabelecer uma regra, que funcione em cem por cento dos casos, o que é impossível. Em sua última tentativa, tem um pequeno vislumbre de que talvez sua teoria seja errada, de que não tenha conseguido, mas prefere internar-se na Casa Verde do que admitir que, em anos de estudo, não tinha chegado a lugar nenhum, continuava no mesmo ponto onde começara.

Ráguin não consegue relacionar-se com os outros porque não é um homem de ação. Para ele, é difícil ter que sair de si e ir ao encontro ao outro. Não sabe como se expressar, tem dúvidas sobre se será entendido. Sabe que as irregularidades na cidadezinha existem muito antes de sua chegada e não teve coragem para mudar nada. Para ele, como dirá inúmeras vezes na novela: "tanto faz".

Curiosamente, mesmo sendo tão diferentes, Bacamarte e Ráguin são sujeitos que detêm o poder, mas têm maneiras diferentes de usá-lo. O poder de Bacamarte é maior, é uma espécie de rei de Itaguaí, o que é muito irônico, já que se trata de uma pequena vila.

O poder de Andréi é mais moderado, está a serviço das autoridades locais, sua função é estabelecer a ordem. Cabe a ele atender os doentes, ainda que seja para enganá-los, mas apenas como medida para manter a ordem. A figura do médico, ainda que seja uma charlatanice, funciona como um placebo para os pacientes. Sua existência é suficiente para 
acalmá-los, pois acreditam no poder do médico e da Medicina. Além disso, a tarefa de livrar a cidade dos incômodos doentes mentais é também exercida pelo médico.

Outra semelhança na composição dos dois personagens são as relações pessoais de cada um: Ráguin tinha um único amigo na cidadezinha, o chefe dos Correios, Mikhail Avierânitch; Simão Bacamarte também tem um único amigo, o boticário Crispim Soares.

Através dessas relações é possível determinar algumas características dos dois protagonistas. Ráguin não tem, de fato, nada para conversar com o chefe dos Correios, gosta de sua companhia para beber cerveja e conversar sobre amenidades, mas não é próximo do amigo, ele apenas o tolera. Andréi não olha o amigo nos olhos, apesar de recebê-lo com frequência, eles não são íntimos. No entanto, ele demonstra contentamento ao ver Mikhail Avierânitch, é uma companhia que interrompe sua solidão.

As relações de Simão Bacamarte, por sua vez, são todas frágeis e rasas. Ele é casado com uma senhora "não bonita nem simpática", mas com "condições fisiológicas e anatômicas de primeira ordem", seus relacionamentos não são baseados no afeto. Isso porque deseja ter um filho, e dona Evarista parece reunir todas as qualidades para isso, o que não acontecerá.

O boticário, que é um personagem leve e simpático na novela, é um amigo, com o qual Bacamarte divide suas descobertas. A amizade oferecida por Crispim Soares ao alienista, como se pode adivinhar, não é correspondida da mesma maneira, porque Bacamarte está focado nos seus objetivos. O boticário é o fiel escudeiro do médico, aquele que oferece apoio irrestrito, chegando a permitir que sua esposa, da qual nunca havia se separado, viajasse para o Rio de Janeiro para fazer companhia à esposa do amigo. Além disso, permitiu até que a esposa fosse internada na Casa Verde.

Quando as esposas viajam, e os maridos estão voltando para casa, o narrador diz:

Crispim Soares, ao tornar a casa, trazia os olhos entre as duas orelhas da besta ruana em que vinha montado; Simão Bacamarte alongava os seus pelo horizonte adiante, deixando ao cavalo a responsabilidade do regresso. Imagem vivaz do gênio e do vulgo! Um fita o presente, com todas as suas lágrimas e saudades, outro devassa o futuro com todas as suas auroras ${ }^{96}$.

Nesse trecho, que talvez seja a passagem mais bonita de toda a novela, Hélio Guimarães $^{97}$ nota que as oposições criadas entre o farmacêutico e o alienista fazem uma clara

\footnotetext{
${ }^{96}$ ASSIS, 2011, pp. 49-50.

${ }^{97}$ Hélio Guimarães é o responsável pelas notas dessa edição. In: ASSIS, 2011, p. 50.
} 
alusão a Dom Quixote, de Cervantes, na qual Crispim Soares é comparado a Sancho e Simão Bacamarte a Dom Quixote.

As duas amizades são bem diferentes, mas têm um ponto em comum, nos dois casos, os médicos se veem como superiores aos seus amigos, consideram-se mais inteligentes. Para Simão, essa posição de superioridade é da natureza dele, não se trata de arrogância deliberada, e Ráguin deixa isso explícito sempre, falta a ele ânimo para ter uma grande amizade.

Além disso, nas duas novelas, seus amigos se tornam traidores. Aumentando ainda mais a semelhança de Simão Bacamarte com alguma figura messiânica, Crispim trairá o amigo assim como Pedro traiu Jesus.

Por ocasião da Revolta dos Canjicas, Crispim fica apavorado com a vitória do barbeiro Porfírio, que tomara a Câmara, além disso, conhece o ódio que as pessoas têm por Simão Bacamarte. Não sabia o que fazer, de que lado ficar. Fingiu que estava doente para não ter que tomar uma atitude. No entanto, decide ir à Câmara mostrar apoio a Porfírio. Uma vez que Bacamarte continuou no poder e soube da adesão do boticário aos Canjicas, mandou capturar o amigo. Não se trata de vingança, Crispim foi internado porque sempre concordava com tudo, o que era um sintoma de loucura. Essa passagem é ambígua, o narrador sugere não se tratar de vingança, até mesmo porque Bacamarte está acima dos sentimentos mortais, mas a coincidência é muito grande para não ser.

Ráguin será traído pelo amigo, chefe dos Correios, que fora facilmente convencido por Khóbotov, o médico auxiliar, de que o amigo estava louco. A surpresa acontece quando Ráguin é chamado para uma reunião com autoridades locais e lá está o amigo, que fará parte do interrogatório, que é uma armadilha pensada por Khóbotov.

A traição sofrida por Simão Bacamarte não tem efeito sobre a sua vida, a única alteração é que passa a considerar o amigo louco, só a loucura explicaria tal ato. A vida de Simão Bacamarte não é alterada pelos acontecimentos do mundo à sua volta, pois está voltado para os seus estudos e não é capaz de ver os outros como pessoas, mas apenas como um conjunto de sintomas, só ele mesmo é capaz de alterar algo em sua própria vida, o que acontecerá quando decide internar-se na Casa Verde.

Ráguin constrói em torno de si uma redoma, por não ter força para mudar a sua própria realidade, escolhe poupar-se sempre e viver alheio ao que se passa com os outros. No 
entanto, um acontecimento importante mudará a sua vida: a descoberta de Ivan Dmítritch Gromov.

A estranha harmonia que é construída durante a novela até o capítulo oito é interrompida no capítulo nove, quando, pela primeira vez, o médico conversa com Ivan Dmítritch Gromov, um louco.

O capítulo é iniciado assim: "De uma feita em fins de março, à noitinha, quando não havia mais neve sobre a terra e estorninhos cantavam no jardim do hospital, o doutor saiu para acompanhar até o portão o seu amigo chefe dos Correios ${ }^{98}$." A neve tinha ido embora, a terra voltava a se aquecer, a natureza renasceria. É nesse momento, que algo em Ráguin também descongelará.

Ráguin nunca conversava com os doentes, mas um dia, sem querer, ficou na frente de Gromov, que começou a ofender o médico e ele não pôde ignorar, resolveu conversar com o paciente. No entanto, ele descobriu algo que mudou a sua existência, Gromov era não só um rapaz agradável, mas também muito inteligente. Ráguin dirá depois que é o único cidadão inteligente da pequena cidade.

A partir desse fato, Ráguin se tornará uma pessoa diferente: perde a hora do jantar, da cerveja, se esquece do velho amigo, o chefe dos Correios, que, até então, era sua única companhia, além da empregada Dáriuchka. Vive em função da próxima conversa que terá com Gromov e, depois de conversar com ele, fica muito tempo ruminando o assunto tratado. "Passou a visitar o pavilhão diariamente. Ia lá de manhã e depois do jantar, e, muitas vezes, a treva noturna encontrava-o ainda conversando com Ivan Dmítritch ${ }^{99}$." Todos no hospital passaram a desconfiar do comportamento do médico, não entendem o que pode haver de interessante num louco.

A importância dessa descoberta está no fato de que Ráguin conhece uma outra pessoa que pensa na cidadezinha, que, para seu infortúnio, é um dos internos da Enfermaria $n^{\circ} 6$. O médico, que sempre teve uma vida calma, sem exaltações, sem nenhuma preocupação, depois de conhecer Gromov, é como se tivesse olhado para um abismo que o atrai, não pode escapar dos acontecimentos que são desencadeados por esse encontro, a vida, que antes era para ele apenas uma abstração da qual nunca tivera que tomar conhecimento, tornara-se algo concreto.

\footnotetext{
${ }^{98}$ TCHEKHOV, 2007, p. 210.

99 Ibidem, p. 222.
} 
Ráguin não era o mesmo e as pessoas também não eram mais as mesmas com ele. $\mathrm{O}$ chefe dos Correios chega a sugerir que o médico está ficando doente devido à bebida, apesar do alcoolismo aparecer na novela como algo "normal", todos estão sempre com o nariz vermelho: o barbeiro, o guarda Nikita e o próprio médico.

Após o interrogatório, que acontece apenas para formalizar a situação, já que Ráguin fora julgado e condenado mesmo antes desse dia, ele se sente ofendido e zangado pela primeira vez na vida. Era também a primeira vez que não ficava indiferente a uma situação.

Então, o chefe dos Correios, vendo a confusão em que se metera o amigo, resolve convidá-lo para uma viagem e insiste que ele deve ir, pois fará bem à sua saúde. Andréi viaja com Mikhail Avierânitch para Moscou, São Petersburgo e Varsóvia. Quase não sai do quarto de hotel, quando isso acontece, se aborrece, o que demonstra sua dificuldade para adaptar-se à mudança, a espaços desconhecidos. Apesar de sonhar com uma vida fora, quando isso acontece, tudo lhe parece fastidioso.

O médico não é casado. Quase não há figuras femininas na novela, só Macha, a filha do vigia; Dáriuchka, a empregada de Andréi; e a "mulher feia", que vivia com Khóbotov. Como acontece com alguma frequência na obra de Tchekhov, a cura de todos os males é sugerida por Mikhail Avieriânitch, é o casamento.

Podemos citar na obra de Tchekhov o conto "Um homem no estojo", em que o protagonista detesta a vida em sociedade, gosta de estar sempre em casa, é um professor reservado, cumpridor dos seus deveres morais, até exageradamente, e seus colegas resolvem casá-lo, como uma cura para sua "anormalidade", claro que isso não acaba bem. O celibato é combatido pela sociedade, nas obras de Tchekhov, como se fosse uma doença.

Quando resolve viajar com o amigo é que a fragilidade dessa relação fica evidente. Eles não têm nada em comum, a convivência forçada é insuportável para o médico, que fica sem ter para onde fugir. Ráguin descobre que o amigo era alguém absolutamente estranho para ele, além de ser um embotado (em russo: mynoŭ), termo que Ráguin usará inúmeras vezes a partir desse momento, não partilham de nenhum gosto.

Ao retornar da viagem, Ráguin descobre que não era mais o diretor do hospital e que estava expulso do apartamento hospitalar. Muda-se então para uma pensão de apenas três quartos, na qual moravam cinco pessoas, sendo ele o sexto morador. 
Certo dia, ao receber a visita de Mikhail Avieriânitch e Khóbotov, Ráguin tem um acesso de raiva, chama-os de estúpidos e embotados. Esse evento acontece no capítulo dezesseis, até ali, e provavelmente durante toda a sua vida, Ráguin jamais se exaltara. Arrepende-se de ofender o único amigo e lhe pede desculpas na manhã seguinte, mas o amigo não ficara ofendido, porque achava que Ráguin estava doente. A explosão de Ráguin era o motivo que Khóbotov precisava para interná-lo na Enfermaria n ${ }^{\circ} 6$ por loucura.

O uso constante da palavra "embotado" marca também a nova forma de agir de Ráguin, pois ele acredita que é o oposto disso. Mas, antes, ele parecia tão embotado quanto o amigo e o médico auxiliar.

O médico não recebe sua aposentadoria, é expulso do cargo e da casa, evidenciando um esquema de corrupção, que nem sequer é escamoteado. Não há explicações sobre o que aconteceu a Ráguin, porque ninguém vai cobrá-las, ninguém tentará libertar o médico, que já havia sido considerado louco pelo restante da cidade. A aprovação dos moradores é facilmente conseguida, bastou um boato de que o médico conversava com um louco durante horas.

\subsubsection{Ráguin e Gromov}

Ivan Dmítritch Gromov seria, se "Enfermaria n $n^{\circ}$ " fosse um filme, o ator coadjuvante da história, função que o narrador demora a revelar, fazendo crer, no início, que esse personagem seria o principal, isso porque ele é apresentado antes do protagonista. Sua história nos é narrada nos capítulos dois e três, apenas a partir do capítulo cinco, Ráguin começa a aparecer como possível protagonista da narrativa. Somente ao final do capítulo três, encontraremos Ráguin internando Gromov.

Ao contrário dos outros internos da enfermaria, Gromov é nobre, tem por volta de 33 anos, é educado, serviçal e extraordinariamente delicado com todos, assim como Ráguin.

Gromov é o único com um diagnóstico claro - mania de perseguição -, que é uma fase da loucura ${ }^{100}$, todos os seus raciocínios são lógicos, mas o ponto de partida é falso. Todos os seus parentes morreram de forma terrível. Assim como Ráguin, falava com voz de tenor. Gromov apanhava do pai e Raguin foi obrigado a ser médico pelo seu pai, e ambos confiam num futuro melhor.

\footnotetext{
${ }^{100}$ Segundo as tabelas de Philippe Pinel, Jean-Étienne Dominique Esquirol e Jean-Martin Charcot.
} 
A "loucura" de Gromov é desencadeada pela visão que ele tem dos presos: “Anteriormente, Ivan Dmítritch encontrara presos com muita frequência, e sempre lhe suscitaram sentimentos de comiseração e constrangimentos, mas dessa vez o encontro causoulhe uma impressão peculiar, estranha ${ }^{101 "}$.

A partir de uma apresentação mais minuciosa de Ráguin, que é realizada no capítulo cinco, começam a surgir elementos, que supõem um paralelismo entre Ráguin e Gromov. Eles têm personalidades parecidas, foram criados por pais autoritários, são educados, suas vozes são parecidas. Aos poucos, Ráguin vai se tornando igual a Gromov.

Ráguin descobre o melhor amigo que poderia ter na Enfermaria n ${ }^{\circ}$ 6. É em Gromov que o médico encontrará as afinidades que não tinha com o chefe dos Correios. A oposição entre o eu e o exterior aparece nessa relação. Ráguin é chamado a olhar o mundo à sua volta através do contato com Gromov, o mesmo acontece com Gromov, que encerrado na enfermaria, terá a oportunidade de conversar com alguém de fora, pois não há contato com os doentes, que são todos alienados.

O médico e Gromov são inteligentes, leem, buscam explicações racionais para a vida, mas estão mergulhados dentro de um universo absurdo, no qual o que importa é quem detém o poder, nesse caso, exercido por uma rede de práticas impossível de ser rompida com o uso da razão.

Após ver os presos, Gromov encontra com um antigo amigo, agente policial, que resolve caminhar com ele um pouco, o que também lhe pareceu muito estranho. A visão dos presos combinada à do policial deixou Gromov apavorado. Ele tinha pavor de ser acusado e indevidamente preso por isso. Desse dia em diante, a vida de Gromov nunca mais foi a mesma, sempre com pavor de ser preso, exaltava-se a qualquer batida mais forte na porta e não conseguia mais dormir. Foi desistindo aos poucos do trabalho, do qual nunca gostou.

Certo dia, na primavera, descobriram dois cadáveres perto do cemitério, uma velha e um menino, que pareciam ter sido mortos violentamente. Ivan teve medo que desconfiassem de que ele fosse o assassino. Resolveu trancar-se na adega da senhoria, depois foi para o seu quarto, por causa do frio, mas não dormiu, e cedo ele ouviu o limpa-chaminés chegando, e, por algum motivo, pensou que fossem policiais disfarçados. Saiu correndo pela rua sem chapéu nem casaca, o que chamou a atenção das pessoas, tudo o que ele não queria que

${ }^{101}$ TCHEKHOV, 2007, p. 189. 
acontecesse. Na casa da senhoria, chamaram o médico, que lhe receitou compressas e gotas de louro e cereja, remédios paliativos, que de nada adiantariam. Por não ter parentes para ajudálo, Ivan foi internado no hospital e de lá nunca mais saiu. O próprio doutor Andréi foi quem levou Ivan.

Ainda que racionalmente ele sabia que seus medos eram infundados, não consegue se convencer disso. O seu pavor é crescente, ele tenta lutar contra ele com argumentos racionais, mas não consegue. O narrador compara a luta de Ivan ao "episódio em que um ermita quis desbravar para si uma areazinha numa floresta virgem: quanto mais aplicadamente ele trabalhava com o machado, tanto mais densa e forte crescia a mata".

Após um ano da internação de Gromov, os habitantes da cidade não lembravam mais dele. Uma espécie de morte em vida é imposta àquele que fica "louco". Raguin também foi internado na primavera. No entanto, a doença de Gromov, em um ano, não evolui para o próximo estágio.

Ráguin vai ficando cada vez mais parecido com Gromov. Pouco antes de ser considerado louco, o narrador diz sobre Gromov: "Mas, em compensação, enfraquecera num grau considerável o seu interesse pelo mundo exterior, particularmente em relação aos livros, e a memória começou a traí-lo fortemente ${ }^{102 \%}$.

O médico vai adquirindo as mesmas características dos internos: faz movimentos mecânicos repetidos, caminha de um lado para o outro, passa muito tempo pensando. Não conseguia mais evitar pensar nas pessoas, no interrogatório, e ele deixa de passar os dias lendo, sofrendo o mesmo processo pelo qual passara Gromov quando começou a ficar "paranoico".

Nunca havia pensado na situação daqueles doentes seriamente, nos motivos pelos quais estavam internados. Seriam realmente loucos? Deveriam ser privados do convívio em sociedade? Quando finalmente se dá conta do horror da situação, ele está preso na mesma armadilha, já não pode fugir, ele também tinha sido julgado e condenado arbitrariamente.

Com a dor, mordeu o travesseiro e apertou os dentes, e de súbito em sua cabeça apareceu nitidamente, e meio ao caos, um pensamento terrível, intolerável: aqueles homens, que pareciam, com o luar, sombras negras, tiveram que suportar dia após dia, no decorrer de anos, uma dor perfeitamente idêntica. Como podia ter acontecido que, durante mais de 20 anos, ele

102 Ibidem, p. 235. 
não soubera e não quisera saber disso? Ele não sabia, não tinha noção da dor, quer dizer que não era culpado, mas a consciência, tão rude e implacável como Nikita, obrigou-o a ficar frio, do occipício aos calcanhares ${ }^{103}$.

Na manhã seguinte, acorda com a mesma indiferença de sempre, marcada pela sua expressão mais repetida: "Não vou responder... Para mim tanto faz".

Após conversar com Gromov e passar pelo interrogatório, Ráguin passa por um processo que vai tornando-o cada vez mais semelhante aos doentes da Enfermaria $n^{\circ} 6$. Apesar de terem o mesmo final, Simão Bacamarte passa por um processo diferente, o alienista havia mudado a sua teoria mais de uma vez, e, ao tentar definir quem era louco observando diferentes características nas pessoas, acabou por desenvolver uma teoria que previa sintomas que só ele possuía, tornando-se presa do seu próprio método.

\subsection{Moderno X Arcaico}

No hospital onde está localizada a Enfermaria $n^{\circ}$ 6, há referências religiosas: retratos de arcebispos, uma vista do mosteiro de Sviatogórsk. Sierguéi Sierguéitch, o barbeiro, "bêbado e sorridente", é religioso, faz com que os doentes digam acatitos aos domingos e depois percorre as enfermarias esparzindo incenso nelas. O próprio médico auxiliar, Khóbotov, sugere que seja feita uma defumação na enfermaria.

Num hospital psiquiátrico, que deveria ser laico, acontecem rituais religiosos sem nenhuma interferência, já que Ráguin, o diretor do hospital, não se preocupa com nada. A convivência entre o divino e a ciência é mais um elemento que compõe a atmosfera de absurdo da novela.

Ráguin demonstra apreço pela religião, gostaria de ter sido eclesiástico, mas o pai o impedira, nas suas conversas com Gromov, invoca a Deus. O elemento religioso é representado em "O Alienista" pela figura do vigário Lopes, que funciona como um contraponto ao cientificismo exagerado de Bacamarte. O padre está sempre presente em todas as decisões importantes para Itaguaí.

Simão Bacamarte, que representa a ciência na novela, acha interessante uma citação do Corão sobre os doidos e manda gravá-la na Casa Verde:

103 Ibidem, p. 247. 
Como fosse grande arabista, achou no Corão que Maomé declara veneráveis os doidos, pela consideração de que Alá lhes tira o juízo para que não pequem. A ideia pareceu-lhe bonita e profunda, e ele a fez gravar no frontispício da casa; mas, como tinha medo ao vigário, e por tabela ao bispo, atribuiu o pensamento a Benedito VIII, merecendo com essa fraude, aliás pia, que o padre Lopes lhe contasse, ao almoço, a vida daquele pontífice eminente ${ }^{104}$.

A novela de Machado de Assis é repleta de referências religiosas, como acontece em quase toda a sua obra, há várias alusões e metáforas bíblicas. O que demonstra a convivência entre religião e ciência naquele período. A religião representa um traço arcaizante presente no século XIX no Brasil e na Rússia, talvez em todo o Ocidente, e não apenas naquele século, mas até os dias de hoje, em menor medida.

Na segunda metade do século XIX, com as descobertas científicas, as religiões perderam adeptos, que passaram a acreditar num mundo mais objetivo, determinista, materialista. No entanto, religião e ciência estavam, e ainda estão, presentes no cotidiano dos indivíduos das grandes cidades do mundo. Em outras palavras, o moderno e o antigo passam a conviver na época de Machado de Assis e Tchekhov, mesmo num mundo cada vez mais modernizado.

Marshall Berman tem uma visão paradoxal da modernidade e do que vem a ser moderno. Isso porque, se por um lado o novo carrega uma série de possibilidades e promessas de melhorias, ele pode vir a desencadear a perda de tudo aquilo que já foi conquistado pelas gerações anteriores. Para ele, este é o paradoxo da experiência moderna, por isso ansiamos pelo novo, mas não abrimos mão do velho ${ }^{105}$.

Partindo dessa premissa, Berman tenta compreender como diferentes épocas e lugares tentaram apreender o que é moderno, e o que é viver na modernidade. Ele divide a história da modernidade em três fases: a primeira vai do início do século XVI até o final do XVIII, em que as pessoas ainda não percebem nitidamente os movimentos da modernidade, ainda que já estejam vivenciando experiências ligadas a ela.

A segunda fase tem início após a Revolução Industrial. É neste momento que surge o conceito paradoxal de modernidade apontado por Berman. As pessoas vivem em meio às revoluções, presenciam mudanças políticas, econômicas e sociais, mas, ao mesmo tempo, se dão conta de que as transformações não ocorreram em todos os setores e que nem todos

\footnotetext{
${ }^{104}$ ASSIS, 2011, pp. 41-2.

105 BERMAN, Marshall. Tudo que é sólido desmancha no ar. São Paulo: Companhia das Letras, 2008.
} 
podem experimentar os benefícios das novidades. Surge então um ambiente em que passado e futuro parecem conviver, assim como todas as contradições de viver em um mundo moderno.

É nessa segunda fase que viveram Machado de Assis e Tchekhov, e a obra dos dois autores apresenta essa dualidade, como um deus Janus que olha ao mesmo tempo para o passado e para o futuro.

$\mathrm{Na}$ terceira fase, que, de acordo com Berman, começa a partir do século $\mathrm{XX}$, os fenômenos ligados à modernidade se espalham por todo o globo. Uma vez espalhado por diversas regiões, suas características essenciais e os motivos que causaram o processo de modernização se perdem.

A existência de um barbeiro, aquele capaz de realizar alguns procedimentos curativos, que hoje são tidos como inúteis e até prejudiciais em alguns casos, nas duas novelas, num momento em que a psiquiatria se modernizava em toda a Europa soa bastante contraditória ao leitor dos dias de hoje. Tchekhov, antes mesmo de a prática entrar em desuso, coloca em sua triste novela "Os mujiques" (Мужики), um personagem que morre após receber o tratamento com sanguessugas ${ }^{106}$, que é basicamente o único oferecido pelo barbeiro.

Ainda que o narrador não ofereça a data precisa de quando viveu o alienista na cidade de Itaguaí, podemos ler a novela como uma paródia do Rio de Janeiro na segunda metade do século XIX.

É importante ressaltar que o barbeiro Porfírio é o responsável pela Revolta dos Canjicas, a rebelião que queria o fim da Casa Verde e de seu diretor. Essa é uma clara alusão ao embate entre moderno e arcaico, de um lado está o Brasil que quer se modernizar, e, do outro, a resistência daquele que quer manter tudo como está. Cada um defende aquilo em que acredita, é compreensível que aqueles que detêm os novos conhecimentos queiram vê-los colocados em prática o quanto antes, e que demonstrem uma certa aversão aos antigos procedimentos. Por outro lado, sempre haverá os que temem o novo, não só por receio pessoal, mas também, como no caso do barbeiro, por ganância, já que o novo coloca em desuso seus conhecimentos, fazendo-o perder dinheiro.

\footnotetext{
${ }^{106}$ Durante milênios, uma das principais medidas terapêuticas utilizadas no mundo foi a sanguessuga, um verme capaz de chupar o sangue das pessoas. Acreditava-se então que as doenças, qualquer doença, eram causadas por problemas de concentração do sangue, o que poderia ser resolvido com uma simples sangria. Como a especialidade desse verme é justamente chupar o sangue de seus hospedeiros sem causar desconforto, o tratamento se tornou popular.
} 
Antonio Candido nota que Machado de Assis disfarça com traços arcaizantes alguns temas modernos para o seu tempo e que viriam a ser característicos da ficção do século $\mathrm{XX}^{107}$. Como em "O Alienista", que trata de um tema novo na literatura brasileira, a loucura, mas principalmente aborda a questão da implantação dos hospícios no Brasil, e a função da psiquiatria. No entanto, utilizará para isso um narrador situado em algum ponto do Brasil Colônia, contando antigas crônicas de uma pequena vila.

Também na "Enfermaria $n^{\circ} 6$ " haverá uma revolta, ainda que mais sutil que a machadiana. Khóbotov, o médico auxiliar, liga-se ao enfermeiro Sierguéi Sierguéitch e ao tesoureiro, convence as autoridades centrais da cidadezinha, inclusive o médico do distrito, de que Ráguin está louco.

Durante o interrogatório, Andréi sugere que o atendimento médico deve ser feito pelo ziemstvo, autoridade local. No entanto, Khóbotov, que é contratado pelo ziemstvo, não quer que este seja responsável pela assistência médica, é, portanto, um traidor. Ráguin, que é contratado pelas autoridades centrais, quer que a decisão passe às autoridades locais e declara isso diante de seus juízes, que são autoridades centrais, indo, portanto, contra os interesses destes. Isso faz com que ele se torne, ainda mais, uma pessoa indesejada.

Quando Khóbotov quer fazer todos acreditarem que Ráguin está louco, ele se articula com as pessoas na cidade que querem que tudo permaneça como está: o barbeiro e as autoridades. Também é possível depreender da novela que a conversa de Ráguin com Gromov representasse uma ameaça a Khóbotov, pois sugere uma nova prática clínica, um tratamento que se baseia também nas conversas. Khóbotov deve temer que Ráguin, a partir do momento em que começa a conversar com Gromov, queira implantar novas formas terapêuticas. E, numa combinação de interesses, ele utiliza as conversas entre Ráguin e Gromov para provar que o diretor está louco, assim ele pode não só manter tudo como está, como é vontade de todos, como também pode tomar o cargo de diretor para si.

${ }^{107}$ Candido, 1995. 


\section{Jacobina e Queridinha: dois protagonistas}

Preciso ser um outro / Para ser eu mesmo Mia Couto ${ }^{108}$

Jacobina ${ }^{109}$ é o protagonista do conto "O Espelho", de Machado de Assis, que foi publicado no mesmo volume que "O Alienista", do qual acabamos de tratar: Papéis Avulsos, de $1882^{110}$. Queridinha (Душечка ${ }^{111}$ ) é a personagem que dá título ao conto de Tchekhov, que foi publicado em 1898, num popular jornal da época A Família (Семья).

Alfredo Bosi denominou alguns contos de Machado de Assis como "contos-teoria". Nesses contos o tom não é abertamente satírico, nem indignado, nem paciente, é um humor de observador, que analisa a necessidade que os homens têm de estarem ligados à aparência dominante $^{112}$. Os contos de Tchekhov costumam afastar-se da formulação teórica. "Queridinha”, por exemplo, está mais próximo de um retrato sobre a condição da mulher na Rússia tsarista.

Nos contos-teoria são desenvolvidas teorias sobre o comportamento humano. A essência dessas proposições está na relação entre o "eu" subjetivo e "eu" social. Contos como "O Espelho", "A teoria do medalhão", "O segredo do Bonzo" e "Um homem célebre" tratam das diferentes formas dessa relação. Em todos esses contos, a aparência vence. A alma pública (externa) está acima da alma subjetiva (interna). Dos contos citados por Bosi, somente "Um homem célebre" foi publicado em Várias Histórias, de 1886, os demais aparecem em Papéis Avulsos. O que demonstra uma preocupação do autor com o tema.

O mesmo assunto será abordado por Tchekhov diversas vezes em sua obra mais tardia, após 1888, como é o caso de "Homem num estojo" (Человек в футляре), de 1898, “Uma

\footnotetext{
108 Do poema “Identidade” In COUTO, Mia. Raiz de Orvalho de outros poemas. São Paulo: Leya, 2011.

109 Jacobina é um nome forte, que retoma a história dos jacobinos franceses. Os primeiros jacobinos eram camponeses e pequeno-burgueses, de pensamento radical, desejavam o extermínio da nobreza. Receberam esse nome porque inicialmente reuniam-se no mosteiro dominicano de São Tiago na França. Tiago é Jacobus em latim. Eram contra a Monarquia, queriam a implantação da República. Os jacobinos são considerados o primeiro grupo revolucionário moderno e tiveram papel importante na criação de algumas leis após a Revolução Francesa.

${ }^{110}$ Originalmente publicado na Gazeta de Notícias em 1882.

111 Significa literalmente "alminha", forma comum e carinhosa de chamar as mulheres na Rússia. Coincidentemente, alma é o mesmo termo utilizado por Machado de Assis, para tratar da teoria apresentada em "O Espelho".

112 BOSI, Alfredo. O enigma do olhar. São Paulo: Martins Fontes, 2007, p. 85.
} 
história enfadonha" (Скучная история), de 1889, “A dama do cachorrinho" (Дама с собачкой), de 1899, entre outros. No entanto, a abordagem de Tchekhov é diferente da de Machado de Assis, pois o autor russo problematiza a relação do sujeito moderno com a existência de uma identidade social. Na obra tchekhoviana, a identidade subjetiva e a identidade social estão sempre em conflito, mas a tendência é que a identidade subjetiva seja sempre uma voz que convida o sujeito para um encontro com suas origens, em alguns casos é atendida e em outros não; enquanto na obra machadiana, a identidade social é a grande vencedora.

Embora "Queridinha" não se enquadre na categoria de conto-teoria definida por Bosi, já que não possui as teorizações que estão presentes em alguns contos machadianos, é possível para o leitor decodificar ao menos uma teoria sugerida pela narrativa, composta de episódios essenciais da vida de Ólenka, que diz respeito ao papel da mulher na sociedade russa no final do século XIX, pelo menos de uma parte das mulheres.

O formato conciso e episódico do conto é um meio excelente para demonstrar teorias. Isso porque com um acontecimento isolado na vida de um personagem é possível obter uma amostra para a teoria, e, com outros poucos exemplos, verificáveis, "provar" sua eficácia. Machado de Assis zomba dessa fórmula constantemente, própria do cientificismo exagerado de sua época, pois dizer que uma teoria é empiricamente comprovada não quer dizer que ela seja verdadeira sempre, afinal, para cada regra, sempre haverá inúmeras exceções, como a própria obra do autor demonstra.

$\mathrm{Na}$ aproximação feita entre as novelas "O Alienista" e "Enfermaria no 6", os protagonistas e os fatos narrados em torno deles tinham a mesma importância. Buscamos entender, a partir de semelhanças e diferenças, porque Machado de Assis e Tchekhov escolheram tratar da situação do louco naquele momento. Antes do tema da loucura, o que estava em pauta para esses autores, àquela altura, era o sujeito da segunda metade do século XIX, e a condição do alienado era mais uma das tantas questões que envolviam esse sujeito.

O nosso foco agora se voltará exclusivamente para os heróis dos contos "O Espelho" e "Queridinha", ou melhor, anti-heróis, já que são sujeitos comuns. Ainda que os tempos sejam outros, reconhecemos neles nossas próprias fraquezas, nossas dúvidas e a própria vida que levamos, cotidiana e banal, apesar da enorme oferta de atividades para desenvolver. Segundo Benjamin, o herói moderno não é o herói, é um representante. 
O herói romântico tinha as suas certezas muito claras, idealizava o seu presente e o seu futuro, acreditava nas inúmeras possibilidades de uma vida plena. O anti-herói, o homem comum, que aparece nos contos de Tchekhov e Machado de Assis, está longe disso. As situações, sobretudo as tchekhovianas, não são extraordinárias, fazem parte de um ciclo cotidiano, em que nada nunca muda. Quando algum evento parece único, essa sensação dura uma fração de segundo, porque, na sequência, veremos que ele será "cotidianizado". O cotidiano na obra de Tchekhov funciona como uma prisão, seus personagens estão presos num ciclo de repetição eterno ${ }^{113}$. Talvez não se trate de construir uma atmosfera sufocante por ser pessimista, como é comumente dito, mas de denunciar em sua obra os elementos que tornam isso possível.

Nessa aproximação entre os contos "O Espelho" e "Queridinha", tentaremos entender quem são esses dois personagens - Jacobina e Queridinha. Considerando que ambos podem ser entendidos como alegorias de indivíduos reais do Brasil e Rússia no final do século XIX.

O Brasil tornou-se independente em 1822, fundou suas primeiras faculdades e sofreu várias revoltas nas províncias a partir do ano de 1835. O apoio da população ao abolicionismo surgiu tímido, fortaleceu-se gradualmente, impulsionando a adoção de várias medidas paliativas, até culminar na Lei Áurea, assinada em 13 de maio de 1888. Ainda neste século, em 15 de novembro de 1889, o Brasil tornou-se uma República.

Os dois escritores presenciaram a consolidação do capitalismo. Rússia e Brasil são países em processo de transformação, misto de passado e futuro, velho e novo. Sensação compartilhada por boa parte do Ocidente naquele período. O cenário da Rússia de Tchekhov não era tão diferente do brasileiro. Com a libertação dos servos em 1861 e os novos incentivos oferecidos por Alexandre II (tsar de 1855 a 1881), a entrada de empresas estrangeiras foi favorecida e iniciou-se o processo de industrialização, deixando para trás a Rússia agrícola. Assim como no Brasil, foi na segunda metade do século XIX que começou o processo de urbanização, que alterou não apenas o espaço físico, mas também as relações sociais. As mudanças históricas perpassam os personagens dos contos que serão comparados a seguir.

Começaremos pela história de Jacobina, senhor de meia idade e um dos narradores do conto "O Espelho", que, certa noite, resolve apresentar aos seus amigos uma teoria

${ }^{113}$ CARPEAUX, Otto Maria. “O Acontecimento”. In Ensaios Reunidos: 1942-1978. Rio de Janeiro: Topbooks, 2006, pp. 799-802. 
desenvolvida por ele. A proposição já vem anunciada no subtítulo do conto: "Esboço de uma nova teoria da alma humana ${ }^{114 ",}$. Trata-se da constatação de que cada ser humano tem duas almas, não uma: "Cada criatura humana traz duas almas consigo: uma que olha de dentro para fora, outra que olha de fora para dentro...". Sendo assim, todo indivíduo possui um duplo em si mesmo. Segundo Jacobina, o ser humano não nasce assim, passa a ser a partir das suas relações com o mundo. Além disso, essa alma exterior não é sempre a mesma, ela está em constante processo de adaptação.

De acordo com a teoria de Jacobina, a alma interior é aquela primeira, que nasce conosco, e a alma exterior é uma segunda, que adquirimos ao longo da vida e por solicitações do mundo. Sendo assim, o que o narrador nos diz é que essa segunda alma é de natureza móvel, ela muda de acordo com os interesses do sujeito e é também uma forma de adequar-se à sociedade.

Ao contrário do sujeito romântico, que tinha certeza de suas origens e essas eram tidas como definitivas para o seu caráter, o protagonista desse conto de Machado de Assis não vem de nenhuma família nobre e tradicional, não tem posses, ou seja, a segunda alma é a sua possibilidade de ascensão social, portanto, ela é a determinante para a sua vida, não a primeira alma. A transição dos sujeitos entre as classes era algo ainda muito novo no Brasil, na época em que o conto foi escrito.

Quando tinha 25 anos, Jacobina, rapaz de família humilde, fora nomeado alferes da Guarda Nacional $^{115}$, tornando-se motivo de grande orgulho para a sua família. Junto com o cargo, o jovem adquiriu uma farda, ofertada por amigos, que era o símbolo absoluto de sua promoção. Com ela não era mais Joãozinho, era o alferes Jacobina. O episódio narrado em "O Espelho" trata da primeira vez que Jacobina notou a existência de uma segunda alma, mesmo que ainda não entendesse o seu significado, nem tivesse usado essa denominação.

Tia Marcolina, que morava em um sítio afastado, como toda a família, queria felicitar o sobrinho alferes, chamou-o e o encheu de mimos, lá, ele era também "Senhor Alferes". A tia deu-lhe o melhor lugar à mesa e mandou colocar em seu quarto o espelho que dá nome ao

\footnotetext{
${ }^{114}$ É importante ressaltar que Machado de Assis diz que a teoria ainda é um "esboço", portanto, não é definitiva, é uma conclusão preliminar, que ainda precisa de mais estudos para ser comprovada.

${ }^{115}$ Segundo nota de Hélio Guimarães: "Antiga denominação para o segundo-tenente, posto relativamente baixo na hierarquia militar; a Guarda Nacional foi uma organização paramilitar, criada pela oligarquia escravocrata em 1831, durante o período turbulento da Regência (1831-1840). Sua função era controlar as revoltas nas províncias e os resultados das eleições. Os integrantes da Guarda Nacional deviam ter uma renda anual mínima e arcavam com os custos do uniforme e das armas que utilizavam".
} 
conto. Era uma peça grandiosa, ainda que envelhecida: "Era um espelho que dera a madrinha, e que esta herdara da mãe, que o comprara a uma das fidalgas vindas em 1808 com a corte de D. João VI ${ }^{116 "}$.

Mas, certo dia, a tia teve que viajar, uma filha estava à beira da morte. Jacobina acabou sozinho no sítio. Os escravos, a princípio, continuaram elogiando muito Jacobina, mas tratava-se de um plano, ganharam a confiança do alferes e aproveitaram a noite para fugir. Desse dia em diante, a solidão de Jacobina foi imensa, não havia ninguém que inflasse o seu ego, nenhum elogio. Tinha medo até de olhar-se no espelho.

Até o dia em que resolveu olhar-se no grande espelho e não conseguiu ver-se refletido. A imagem que lá aparece é borrada, indefinida. Resolve então colocar a farda e olhar-se, e a mágica se faz, lá está ele, por inteiro, o alferes Jacobina. Enquanto a tia não voltava, a cura para a solidão foi vestir a farda durante algumas horas por dia e colocar-se diante do espelho. “(...) era eu mesmo, o alferes, que achava, enfim, a alma exterior”.

O conto é centrado no personagem Jacobina, quando ele fala, no presente, todos se calam, e essa é a sua condição para dividir com os quatro cavalheiros a sua experiência, como nas conferências, que estavam na moda naquele período. A princípio, há pequenas intervenções, que logo desaparecem e temos apenas Jacobina narrando o que aconteceu com ele no sítio da tia.

Machado de Assis afasta o seu narrador-protagonista do conjunto família e sociedade, retira-o da cidade, faz com que todos os personagens do sítio desapareçam, e sobram apenas Joãozinho e o espelho. É lá que Jacobina perceberá a metamorfose pela qual passou. O isolamento também permite uma análise psicológica mais eficiente do alferes, que, até então, parecia apenas uma criança sendo adulada. Até esse momento, os fatos narrados falam da relação dos outros com Jacobina e deste com os outros. Agora ele terá que confrontar a sua primeira alma.

Através de uma narrativa linear, que começa com o seu primeiro casamento, conhecemos a história de Ólenka ${ }^{117}$, a "Queridinha". Ela era uma moça comum, filha de um assessor-colegial, mas tinha uma característica especial que o narrador destaca constantemente, estava sempre amando alguém e não podia viver sem isso. $\mathrm{O}$ primeiro amor

\footnotetext{
${ }^{116}$ ASSIS, 2011, p. 213.

${ }^{117}$ Diminutivo de Olga.
} 
fora o pai, depois a tia, um professor, o primeiro e o segundo maridos, na sequência o amante veterinário e, por fim, o filho do veterinário, uma criança.

O primeiro marido de Ólenka foi Kúkin, dono e empresário do parque de diversões Tivoli. O segundo era Vassíli Andréievitch Pustovalov, gerente de um depósito de madeiras. Queridinha ficou viúva desses dois maridos e foi, durante um curto período, amante de um veterinário, que também a abandonou. Todos foram amores intensos.

É necessário esclarecer que o amor de Olga não é do tipo sexual, mas sim um tipo específico de amor, desses que parecem invadir todo o ser, não deixando espaço para mais nada, nem mesmo para a própria existência, como define Tchekhov. Enfim, é um sentimento que existe para preencher um corpo sem alma, é assim que ela se apega a qualquer pessoa que demonstre algum amor por ela.

Queridinha é romântica, num mundo onde o Romantismo não é mais possível. O amor no cotidiano construído por Tchekhov não é idealizado, ele depende de vários fatores para existir.

\subsection{A estrutura dos contos}

A estrutura do conto "Queridinha" é uma repetição de fatos, que é composta a partir da oscilação da condição de Queridinha: amando ou só. O escritor constrói esse movimento gradualmente até torná-lo evidente. De forma que, quando Queridinha estava começando a amar o veterinário, há apenas um parágrafo no qual ela fala algo sobre inspeção veterinária com uma senhora na rua, e o leitor já sabe que a história está se repetindo, o que tem um efeito cômico, porque o mesmo tinha ocorrido com os dois maridos anteriores.

Queridinha, que não tem voz, que não pensa por si só, tem a sua história contada por um narrador, que, às vezes, lhe dá a voz. Nesses raros momentos, ela expressa uma opinião emprestada de uma das pessoas que ama ou amou.

"O Espelho" é um conto todo construído explorando a duplicidade do tema e até mesmo da forma, e, seguindo essa estrutura, possui dois narradores. Um narrador nos apresenta Jacobina, no presente, com 45 anos, em uma casa no Morro de Santa Teresa, conversando com amigos; o outro narrador é o próprio Jacobina, que compartilhará os eventos passados com ele e que o levaram a desenvolver a sua teoria. Os dois narradores representam uma luz que vem de fora e outra que vem de dentro, como no espelho. $\mathrm{O}$ olhar de dentro e o 
olhar de fora, o público e o privado. O olhar de dentro, voltado para si mesmo, e o olhar de fora, que nos constrói.

"O Espelho" é narrado em primeira pessoa, método usado por Machado de Assis pela segunda vez. Sendo a primeira em Memórias Póstumas de Brás Cubas, um ano antes. Além disso, trata-se de um narrador que não é alguém alheio à história, mas o próprio protagonista, o que é uma inovação para a época na literatura brasileira. Na verdade, são dois narradores, o que está de acordo com o esquema do conto, que propõe dois pontos de vista para todos os elementos do conto. "O Espelho" começa sendo contado em terceira pessoa, e logo o narrador passa a voz a Jacobina, que compartilhará com os amigos sua teoria e os acontecimentos que o levaram a desenvolvê-la.

A forma como as histórias são narradas são muito diferentes. O texto de Tchekhov é repetitivo e cíclico, enquanto o de Machado de Assis é dinâmico. Mas há um instante em que a forma das duas narrativas se aproxima, há um adiamento do final. Em ambos, temos a sensação de que a história acabou antes disso de fato acontecer. Em "O Espelho", a descrição de Jacobina no sítio é prolongada ao máximo, e é repleta de detalhes, que levam o leitor a ficar angustiado com a demora do desfecho. O conto de Tchekhov parece terminar após a partida do veterinário, mas não, o momento de maior solidão da protagonista é também prolongado para contrastar com a chegada do menino, que será o evento mais feliz da vida de Ólenka.

\subsection{A formação da identidade: 0 "eu" e o "outro"}

Considerando que identidade é aquilo que define o sujeito, podemos enxergar no que Jacobina chama de alma uma representação do conceito moderno de identidade aquilo que Jacobina chama de "alma". Há, portanto, uma identidade subjetiva (alma interior) e uma identidade social (alma exterior). Para Jacobina, a alma interior é representada pelo ser humano que ele era antes de ser nomeado alferes, antes do contato com a sociedade, que ajudará a compor a sua alma exterior. Queridinha é apresentada sem identidade subjetiva e a identidade social é o papel de esposa.

Jacobina explica aos cavalheiros que o ouvem atentamente que a segunda alma manifesta-se desde muito cedo. Quase como se ela fosse responsável pela vida verdadeira dos indivíduos. Queridinha amou ainda muito cedo seu pai, seu professor e, quando cresceu, substituiu essas relações amorosas pelo casamento. 
O papel que os indivíduos devem assumir na sociedade é um dos assuntos mais importantes do século XIX, sobretudo devido ao capitalismo crescente. Dentro do esquema da nova vida social, os indivíduos devem saber jogar o jogo das identidades. Desde cedo, as crianças são incentivadas a desenvolverem habilidades que as qualifique para a vida em sociedade.

O conto de Tchekhov demonstra que, para Queridinha, que é mulher, existe um papel reservado pela própria configuração da sociedade da época. Para algumas mulheres, só é possível desenvolver uma função social no papel de esposa e mãe. Esse lugar na sociedade é a segunda alma de Queridinha, da mesma maneira que o cargo de alferes é a de Jacobina, no entanto, por ser homem, a sociedade oferece outras formas de ascensão social para ele. $\mathrm{O}$ modo de viver e interagir socialmente desses personagens pode ser entendido dentro do contexto histórico.

No conto “Teoria do Medalhão", Machado de Assis apresenta um diálogo no qual o pai ensina ao seu filho como tornar-se um medalhão até a meia-idade. Trata-se de uma espécie de paródia de $O$ Príncipe de Maquiavel. Todos os conselhos oferecidos pelo pai envolvem o funcionamento da sociedade, como o rapaz deve se comportar, quando e como rir, o que deve estudar. Seguindo a cartilha do pai, Janjão ascenderia socialmente, ao contrário do seu pai, que não teve quem lhe ensinasse. Sendo assim, a receita do sucesso na carreira não envolve uma individualidade autêntica, mas preparo para saber manipular as pessoas, apresentando a elas o que desejam ver. Além do mais, o pai deixa claro que qualquer carreira serve, desde que seja possível tornar-se proeminente dentro dela.

No momento que Jacobina ingressa na Guarda Nacional, está sendo inserido na vida em sociedade, na falta de um pai como o de Janjão, ele teve que aprender sozinho os processos para alcançar novos cargos ao longo da vida. Utilizando a teoria de Jacobina, o pai de Janjão apresentou-o a sua segunda alma antes que ele se desse conta da existência dela, enquanto o alferes descobriu-a sozinho no sítio da tia Marcolina.

Quando Jacobina fica sozinho no sítio da tia, tem um sonho, nele o cargo de alferes aparece apenas como a sua primeira farda, faria carreira militar, alcançando altas patentes, tudo sem grandes esforços, através de favores. No sonho, amigos ofereciam os cargos a Jacobina. Tanto o conto “Teoria do Medalhão" como "O Espelho" evidenciam um mecanismo muito comum utilizado pela sociedade brasileira, o favor. 
O crítico Roberto Schwarz explica a natureza do favor como uma mediação quase universal entre os brasileiros livres (antes da Abolição dos Escravos), que, assim como a escravidão, também é uma herança de nossa colonização.

Esquematizando, pode-se dizer que a colonização produziu, com base no monopólio da terra, três classes de produção: o latifundiário, o escravo e o 'homem livre', na verdade dependente. Entre os primeiros dois a relação é clara, é a multidão dos terceiros que nos interessa. Nem proprietários nem proletários, seu acesso à vida social e a seus bens dependem materialmente do favor, indireto ou direto, de um grande ${ }^{118}$.

Jacobina pertence à terceira categoria descrita por Schwarz e seu sonho revela mais um aspecto do "outro" dentro de uma sociedade em que a lógica da meritocracia capitalista ainda não existia. O sonho de Jacobina é, de certa maneira, a revelação de como será a sua vida, obter favores era a única forma de um homem de origem humilde como ele "fazer carreira".

Schwarz nota ainda que esse processo contraria, ponto por ponto, a lógica postulada pela civilização burguesa: "a autonomia da pessoa, a universalidade da lei, a cultura desinteressada, remuneração objetiva, a ética do trabalho etc.”. O favor demonstra a “dependência da pessoa, a exceção à regra, a cultura interessada, a remuneração e serviços pessoais $^{119,}$. O que prova o argumento do crítico, de que, apesar de o Brasil querer igualar-se de várias maneiras às grandes nações europeias, adotando as ideias de fora, o país tinha uma tendência a fazer "ajustes" nas teorias, adequando-as à realidade brasileira, o que produzia muitas vezes um efeito muito diverso do esperado.

Retomando a definição de Stuart Hall, sobre os “sujeitos sociológicos”, isto é, aqueles que vivem nas crescentes cidades do mundo, envoltos num emaranhado de burocracia, e que convivem com regras que regulamentam todas as instâncias de suas vidas, podemos dizer que Jacobina e Queridinha se enquadram nessa categoria. Ainda que a relação com a sociedade seja muito diferente nos dois casos, como veremos, os dois protagonistas podem ser denominados assim principalmente por serem sujeitos do século XIX.

Apesar da configuração mais coletiva da vida, a perspectiva de que o ser humano é soberano não é abandonada. As leis, apesar de serem desenvolvidas para a massa, tendem a fortalecer a individualidade, reforçando a noção de que existe um sujeito social e um

\footnotetext{
${ }^{118}$ SCHWARZ, Roberto. "Ideias fora do lugar". In: Ao vencedor as batatas. São Paulo: Duas Cidades, 2000, p. 16.

119 Ibidem, p. 17.
} 
subjetivo. Cada pessoa passa então a ter que lidar com essa dualidade, que se torna própria da vida em sociedade.

A partir da modernidade, o indivíduo precisa construir uma identidade pessoal, um “eu”, e combiná-lo com a vida social, que ganha outros contornos. É necessário aprender a viver rodeado por pessoas quase o tempo todo, indivíduos que formam pequenos ou grandes grupos de acordo com os seus interesses ou porque o Estado os colocou juntos. Os sujeitos permanecem dessa forma ligados por suas identidades sociais.

O outro passa então a ser uma figura presente até mesmo quando não está presente fisicamente. Partindo do princípio de que o olhar do outro é constitutivo do "eu", torna-se importante entender como esse processo se dá, assim começam a ser desenvolvidas teorias sobre o processo de socialização. As teorias da socialização mais conhecidas, como a de Talcott Parsons (1902-1979), foram desenvolvidas apenas no século XX, momento imediatamente posterior a essa nova conformação da vida.

O "esboço de uma nova teoria da alma humana", de Jacobina, pode ser lido como uma teoria da socialização, guardadas as devidas proporções, pois seu campo de observação era apenas o Rio de Janeiro de sua época. O que não deixa de ser irônico, já que Jacobina diz que os fatos são tudo e por isso não aceita réplicas durante a exposição da sua tese, que foi desenvolvida tendo como base única e exclusiva a sua própria experiência. Machado de Assis está ironizando o Positivismo, que acreditava que a partir da observação dos fatos era possível compreender o mundo. A semelhança com as teorias da socialização se deve ao fato de investigar o desenvolvimento das identidades dos sujeitos a partir de interações com o "outro".

Com o intuito de comparar com a teoria de Jacobina, apresentamos abaixo a definição de socialização de um Dicionário de Sociologia:

Socialização é o termo utilizado pelos sociólogos para descrever o processo pelo qual as pessoas aprendem a adaptar-se às regras sociais, um processo que torna possível a existência de uma sociedade e a transmissão de sua cultura de uma geração para outra. Esse processo pode ser entendido de duas maneiras: a socialização pode ser concebida como a absorção de normas sociais: o indivíduo internaliza as regras sociais, no sentido de que são autoimpostas e não no sentido de que são impostas por regulamentação externas, e passam, portanto, a fazer parte da personalidade do próprio indivíduo. Nesse processo, o indivíduo é que sente a necessidade de adaptar-se. A segunda forma é que a socialização pode ser concebida como um elemento essencial da interação social, bastando, a princípio, que as pessoas queiram destacar-se para 
obter aceitação e status diante dos outros; neste caso, os indivíduos se socializam ajustando suas próprias ações às expectativas dos outros ${ }^{120}$.

Os dois conceitos podem combinar-se num processo de "interiorização" do exterior e “exteriorização" do interior, segundo a teoria de Parsons (1902-1979). A socialização é então um processo de constituição dos indivíduos e das sociedades, que acontece através de interações entre ambos. Assim os indivíduos produzem a sociedade e são produzidos por ela.

Dessa forma, a socialização é o resultado de sucessivas interações entre o indivíduo e o meio e ocorre sempre no contexto das relações de poder. Isso porque essas interações não se dão de maneira simples, nem naturalmente. O padrão vencedor, aquele que será disseminado, é sempre aquele "inventado" pelas classes dominantes.

A partir da modernidade, mas principalmente após a Revolução Industrial (17601840), o processo de socialização se transformou, em decorrência do crescimento da sociedade e do surgimento de estruturas reguladoras da vida do sujeito, que delimitam sua convivência em conjunto. É então que surge o indivíduo sociológico, convivendo num espaço restrito com uma grande quantidade de pessoas, o que não existia antes.

Os personagens de Machado de Assis e de Tchekhov são contemporâneos, vivem num tempo em que a sociedade estava se modificando, moldando-se às novas necessidades, que surgiram devido ao aumento da população. Queridinha morava em uma província da Rússia, mais uma vez Tchekhov, como em outros contos, não dá nome ao lugar, sugerindo que aqueles acontecimentos não caracterizam nenhum lugar específico, mas qualquer pequena cidade russa, e Jacobina vivia na então capital do Brasil, cidades que, assim como outras do mundo todo, estavam em transição.

O narrador marca a passagem do tempo apresentando todos os locais onde Ólenka morou, que evoluíram enquanto ela permaneceu alheia às mudanças por ter ficado muito tempo só. "A cidade ampliou-se pouco a pouco, em todas as direções. O Arrabalde dos Ciganos recebera já um nome de rua e, no lugar onde haviam existido o jardim Tivoli e os depósitos de madeira, já surgiram casas e uma série de becos ${ }^{121}$." A evolução de Jacobina é

\footnotetext{
${ }^{120}$ Tradução livre de parte do Verbete "Socialización" In ABERCROMBIE, N., HILL, S. e TURNER, B. (orgs.) Diccionario de Sociologia. Madrid: Ediciones Cátedra, 1992.

${ }^{121}$ TCHEKHOV. A dama do cachorrinho e outros contos. (Tradução, posfácio e notas de Boris Schnaiderman). São Paulo: Ed. 34, 2006, p. 309.
} 
evidente, era um senhor de meia-idade: "provinciano, capitalista, inteligente, não sem instrução ${ }^{122 \%}$.

O entorno de Queridinha modificou-se, expandiu-se, os bairros estavam em formação, no entanto, a personagem não acompanha as transformações, está parada no tempo desde que o veterinário a abandonou. Quase não existe processo de socialização para ela sem o intermédio de um marido. A empregada e os vizinhos, que a olham à distância, são suas únicas formas de contato com mundo exterior.

As interações de Queridinha foram sempre feitas através de relações amorosas, seja com a família, com o professor ou com os maridos. Não podemos dizer o que ela "é". Ela foi boa filha, sobrinha, aluna, esposa e mãe. Queridinha não completa o processo de socialização, já que está integralmente voltada para fora, para o outro. Ela interioriza o exterior, mas não exterioriza nada.

É como se durante toda a sua existência ela não passasse da fase do espelho, descrita por Lacan. Na fase do espelho, a criança ainda não possui uma autoimagem completa, se vê ou se imagina refletida inteira no espelho que é o olhar do outro ${ }^{123}$. Esse processo acontece de forma inconsciente, ao contrário da socialização, que é um processo consciente.

Machado de Assis, na segunda fase de sua carreira, compõe personagens mais completos, que poderiam ser aqueles com os quais convivia na crescente sociedade fluminense da sua época, que, ao mesmo tempo, apresentam traços da personalidade humana com grande precisão, tornando-os universais e sempre atuais. Sendo assim, eles têm as particularidades do ambiente em que viviam, mas guardam semelhanças com qualquer indivíduo do mundo. O mesmo pode ser dito de Tchekhov, apesar de ter sido acusado algumas vezes de ser pouco russo, assim como Machado de Assis fora acusado de não tratar dos temas locais. Tchekhov tratava essencialmente dos indivíduos russos, seu cotidiano e suas angústias.

O conto, por tratar apenas de um episódio, não nos oferece um panorama completo da vida de Jacobina, pelo contrário, afasta o protagonista para que possamos observar que efeitos o relacionamento com outros indivíduos teve sobre a personalidade do jovem alferes. $\mathrm{O}$ mesmo ocorre com Queridinha, Tchekhov também a coloca em contato com outros indivíduos

\footnotetext{
${ }^{122}$ ASSIS, 2011, p. 211.

${ }^{123}$ LACAN, Jacques. "O estádio do espelho como formador da função do eu." Escritos. Rio de Janeiro: Zahar, 1998, pp. 96-103.
} 
e depois vamos encontrá-la num isolamento forçado. E é dessa maneira que podemos entender melhor a personalidade dos dois protagonistas.

Machado de Assis acompanhou as mudanças do Rio de Janeiro, que cresceu muito no reinado de D. Pedro II. Ele pôde ver de perto como sujeitos comuns transformaram-se, repentinamente, em homens bem-sucedidos, alguns famosos. Apesar de não ser rico nem herdeiro, como aqueles com os quais convivia, Machado de Assis fazia parte dessa sociedade como cidadão ilustre, mas não era como eles. A sua origem humilde oferecia para ele um olhar privilegiado de quem está dentro, e por isso pode olhar tudo de perto, mas que enxerga diferente dos outros por ser de fora. Curiosamente, o mesmo pode ser dito sobre Tchekhov, que também era de origem humilde, neto de servo de gleba, mas que, por meio do seu trabalho literário, ficou muito conhecido.

Quando o narrador machadiano inicia sua história, ele avisa que não tratará de "certas almas absorventes, como a pátria”, ou seja, não vai falar de nenhuma identidade nacional, que é algo mais complicado de delimitar e que parecia ao narrador de natureza fixa, ao contrário dessa segunda alma da qual ele quer tratar, que é móvel.

Jacobina aborda um fenômeno observado nos sujeitos com os quais conviveu e convivia, a formação da identidade num nível micro, tangível para ele, não num nível macro, que envolveria então toda a história de uma nação. Apesar de lidar com um campo bem delimitado de observação, chama ironicamente sua empreitada de "uma nova teoria da alma humana".

Na sua teoria, o narrador observa, que, nos primeiros anos de vida, a segunda alma pode ser um chocalho ou um cavalo de pau, os primeiros objetos utilizados pelas crianças para se socializarem com outras. A socialização infantil antes acontecia apenas através do contato com os pais, mas, com a criação de espaços coletivos para elas - escolas, clubes -, as crianças passaram a se socializar com um círculo mais amplo (outras crianças e os pais destas) cada vez mais cedo.

Jacobina não aborda a questão dos pais com seus filhos, da etapa primária da socialização, ele fala de uma etapa secundária, em que o indivíduo já faz interações com o outro absoluto, a sociedade. $\mathrm{O}$ autor enfatiza como a sociedade é responsável pela formação do indivíduo desde o primeiro momento, inclusive por meio dos pais, que são também indivíduos impregnados de normas sociais, que eles transmitem aos filhos desde muito cedo. 
São paradigmas da família ideal criado e disseminado pela sociedade. A alma exterior, a identidade social, é a que definirá o sujeito desde os primeiros anos: "Está claro que o ofício dessa segunda alma é transmitir a vida, como a primeira; as duas completam o homem, que é, metafisicamente falando, uma laranja ${ }^{124,}$.

Antigamente, os padrões sociais eram transmitidos de geração para geração, mas, com o crescimento da sociedade e a velocidade das mudanças, as relações foram se tornando mais complexas. Nos dias de hoje, com a globalização, essas interações são feitas de modo completamente diferente das dos nossos antepassados, já que atualmente os padrões dominantes são disseminados numa velocidade impressionante. $\mathrm{Na}$ época de Machado de Assis e Tchekhov, por exemplo, o telégrafo era uma novidade, foi o início da divulgação dos fatos quase em tempo real, antes disso, não havia essa possibilidade. $O$ conhecimento acumulado por aquele que muito viveu e por isso viu muitas coisas é substituído pelo acesso fácil às informações.

A forma como o processo de socialização acontecia começou a mudar radicalmente no século XIX. O crescimento dos meios de comunicação alterou a relação entre as pessoas, não só pela divulgação rápida dos fatos, mas por ser também uma maneira de exaltar algumas personalidades em detrimento de outras: escritores, atores, políticos, pessoas ricas. Tchekhov e Machado de Assis, que publicavam seus contos em famosos jornais da época, conheciam bem o jogo das aparências dominantes. Uma das questões levantadas, e talvez a mais evidente, no conto "Queridinha” é: Qual o papel da mulher na sociedade?

Tchekhov nos apresenta uma personagem que é principalmente excelente companheira, pelo menos para uma parcela da sociedade, já para algumas mulheres e alguns poucos homens esclarecidos, o autor estaria chamando a atenção para um problema, que é a anulação da mulher naquele meio. Pouco compreendido, o autor conseguiu alguma discussão em torno do assunto, mas algumas mulheres que entenderam o conto por esse segundo viés, irritaram-se com a figura feminina apresentada por Tchekhov ${ }^{125}$.

Dessa forma, "Queridinha" também pode ser visto como uma provocação às mulheres da época, uma maneira de mostrar a elas o quanto eram subestimadas pela sociedade russa. No posfácio da edição brasileira de A Dama do Cachorrinho, o tradutor Boris Schnaiderman diz que mulheres proeminentes da época escreveram a Tchekhov criticando sua "Queridinha",

\footnotetext{
${ }^{124}$ ASSIS, 2011, p. 210.

${ }^{125}$ Algumas opiniões estão no apêndice feito por Boris Schnaiderman para TCHEKHOV, 2006.
} 
diziam que o conto enfraquecia a figura da mulher e mostrava a submissão em relação ao homem. Tolstói adorou a mulher apresentada por Tchekhov no conto, dizia que era uma "impressionante figura companheira".

A identidade de gênero é uma das mais fortes que existe. Ser homem ou mulher implica não só em fatores biológicos, mas também na construção histórica da noção de gênero ao longo do desenvolvimento da humanidade, sendo que cada povo possui regras de conduta ligadas a cada um dos gêneros. O papel da mulher dentro da sociedade foi durante muito tempo ser mãe e esposa.

As mulheres da elite russa do final do século XIX e início do XX são reprimidas pelo preconceito social e pela coerção familiar, aquelas que pertencem às camadas mais baixas da sociedade, sofrem também violência. Em diversos contos, Tchekhov demonstrará a maneira como a mulher é tratada, mas também apresentará personagens femininos que conseguem fugir desse ciclo de repressão, violência e submissão.

No início da carreira, Tchekhov representava as mulheres num plano humorístico. Posteriormente, a representação da figura feminina adquire maior profundidade, de modo que essas mulheres passam a apresentar uma história de evolução dentro da narrativa ${ }^{126}$.

O conto "Queridinha" surge num momento em que o autor já compunha personagens femininos mais complexos e com maior profundidade psicológica. Não parece que seja coincidência uma personagem com esse perfil. A princípio, Queridinha parece uma personagem muito simples, rasa, composta sem nenhuma preocupação com a sua psicologia, assemelha-se às personagens femininas do início da carreira do autor, e apresenta ao leitor um padrão de comportamento que seria típico da mulher russa. Quando o narrador tenta um aprofundamento psicológico, o que aparece é o nada, demonstrando a anulação da individualidade da mulher naquela sociedade.

Sendo assim, parece que Tchekhov, que apenas um ano depois iria compor a protagonista do conto “A Dama do Cachorrinho", Ana Serguéievna, uma mulher confusa, mas disposta a mudar a sua realidade, indo em busca dos seus verdadeiros desejos, esteja

\footnotetext{
${ }^{126}$ KUZNETSOVA apud LIMA, RODRIGO FERREIRA. Um estudo da personagem feminina nos contos de Tchekhov. Dissertação de mestrado apresentada ao Programa de Pós-graduação em Literatura e Cultura Russa do Departamento de Letras Orientais da Faculdade de Filosofia, Letras e Ciências Humanas da Universidade de São Paulo, 2012.
} 
denunciando à sociedade em geral que, apesar de existirem mulheres como Ana, ainda existem também mulheres como Queridinha, e em condição pior nas classes mais baixas.

Nenhuma violência física é cometida contra Queridinha, mas há uma violência simbólica $^{127}$, que é o papel reservado a ela como mulher dentro dessa sociedade, que não apenas impede que a mulher seja capaz de mudar a realidade em torno de si, como torna impossível até que ela consiga pensar nisso, assim como suas antepassadas, que foram igualmente ou mais subjugadas pelas pessoas à sua volta do que ela.

A história de Queridinha é contada de maneira a parecer tão cotidiana, porque é, que quase passa despercebido o horror que é não existir fora das funções de mãe e esposa. A estrutura é muito semelhante à utilizada em outros contos de Tchekhov, como em "O Acontecimento", a história é tão banal que por pouco não notamos o que foi o acontecimento. Em "Queridinha", a história é tão corriqueira, que quase ignoramos a importância daquela vida.

Ela não assume nenhuma posição na sociedade, só existe quando está casada, sem um lar e filhos, não existe Queridinha. A segunda alma de Queridinha, a social, não existe sem um companheiro ou filho, ela não tem emprego, não frequenta festas, não tem amigas, não possui passatempos, não cuida de si mesma e da própria casa, todas as suas ações são motivadas pela existência de uma pessoa a quem dedicá-las. "Queridinha” é uma mulher submetida ao patriarcalismo, sem condição de pensar ou agir por si mesma.

Jacobina e Queridinha são personagens do mesmo século, possivelmente até do mesmo quarto de século, são influenciados diretamente pela nova configuração da sociedade, mais urbana e capitalista, por isso se assemelham no fato de que precisam da legitimação de instituições sociais para validarem suas identidades. Ainda que a cada um seja reservado um papel diferente, correspondente ao gênero. Para ele, ainda que seja de origem humilde, é permitido sonhar com uma vida diferente, em que ocupará altos cargos, ganhando bons salários, conquistando assim a admiração de todos. Para ela, que parece ter condições financeiras melhores do que as de Jacobina, não há futuro possível sem um marido, sem

\footnotetext{
127 No sentido de Bourdieu: Uma forma de coação que se apoia no reconhecimento de uma imposição determinada (econômica, social ou simbólica). A violência simbólica baseia-se na fabricação contínua de crenças no processo de socialização, que induzem o indivíduo a se posicionar no espaço social seguindo critérios e padrões do discurso dominante. In. BOURDIEU, Pierre. BOURDIEU, Pierre. Sociologia. São Paulo: Ática, 1983.
} 
alguém a quem servir, por isso todas as suas esperanças são depositadas na criação do filho do veterinário, porque o papel de mãe lhe assegura um lugar na sociedade.

\subsubsection{Quem é esse outro?}

As únicas companhias que restam à Queridinha após o abandono do veterinário são a gata e a cozinheira. A presença de um ser humano talvez seja a única maneira de mantê-la viva: "Bastava-lhe, por exemplo, o que dizia a cozinheira Mavra".

Como foi dito, um ponto determinante para a formação do "eu" é o olhar do outro e a qualidade desse olhar. Jacobina está diante de um olhar de reconhecimento daqueles que veem nele um cargo, que significa um Jacobina melhor, que evoluiu, que merece respeito. Ele não era mais Joãozinho, e Machado de Assis certamente não escolhe este nome ao acaso, um dos nomes mais comuns no Brasil. Ele era agora o alferes, que merecia o melhor lugar à mesa da tia.

"O Espelho" está ambientado no Morro de Santa Teresa, no Rio de Janeiro, onde cavalheiros estão discutindo questões de "alta transcendência". Localizado na parte central do Rio de Janeiro, os mais abastados procuravam esse morro para fugir do calor dos lugares mais baixos da cidade. Isso significa que Jacobina, depois do episódio do sítio da tia, continuou sabendo fazer o jogo da sociedade, pois não é pobre, de outra forma não estaria conversando banalidades enquanto fuma um charuto com os amigos.

Assim como Jacobina no sítio com os escravos, Queridinha encontra-se sozinha na casa apenas com a empregada. Nos dois casos, a presença de outro sujeito serve apenas para garantir um pouco de vida. Jacobina fica menos triste com os escravos, que passam o dia a bajulá-lo, lembrando-o de que é um alferes, e Queridinha não morre por causa da empregada, que pode oferecer um pouco de vida a ela.

Uma pergunta possível é: Por que a empregada não basta à Queridinha?

Queridinha diz precisar de um amor que tome conta de todo o seu ser, "alma e entendimento, que lhe infundisse ideias, desse um sentido a sua vida". Uma resposta presumível é que ela precisava de um amor romântico, no entanto, o novo alvo de seu amor será o filho do veterinário. O vazio que toma Queridinha após a partida do veterinário soa como uma preparação para a chegada do menino, a intensidade de seu sofrimento foi grande e proporcional à felicidade causada pela chegada de Sacha. 
Outra resposta plausível é que, assim como os escravos não bastavam a Jacobina, a cozinheira não era suficiente para Queridinha, apesar de serem melhores do que nada. Isso porque a qualidade do olhar do outro também importa. Nas relações de poder, interessa aos sujeitos serem observados e reconhecidos por um olhar de alguém igual ou superior a eles. No caso de Queridinha, não é apenas por tratar-se da classe social da empregada, mas também porque ela era mulher, portanto, era igual à Ólenka, não podia oferecer um lugar na sociedade. Além do mais, não pode preencher o vazio de Queridinha, pois está ali para lhe servir. Tchekhov constrói um paralelo entre a gata e a empregada, ambas tinham o mesmo valor.

Os relacionamentos amorosos, como todas as relações humanas, podem ser equiparados às relações de poder, em que uma das partes está numa situação estratégica e por isso tentará dirigir a conduta do outro de alguma forma. No caso de Queridinha, ela espera e precisa que um outro apareça e que este sujeito seja, de alguma maneira, superior a ela. Invariavelmente esse papel é desempenhado por uma figura masculina.

A qualidade desse olhar pelo qual Queridinha e Jacobina esperam ser reconhecidos é importante. Quando Jacobina se olha no espelho fardado e volta a se ver, significa que ele achou uma forma de ver a si mesmo como os outros o viam, o que não pode ocorrer com Queridinha, porque ela precisa de uma pessoa real para conferir sentido a sua existência, não é capaz de reviver a experiência sozinha em sua casa.

\subsection{Queridinha através da "nova teoria da alma humana"}

A protagonista que dá nome ao conto de Tchekhov, Queridinha, pode ser interpretada a partir da teoria de Jacobina. A seguir, procuraremos demonstrar como as duas almas operam para formar Queridinha, uma mulher comum, de um vilarejo na Rússia, no século XIX.

A história é narrada contrastando os períodos em que Queridinha está acompanhada com aqueles em que está só. Até mesmo a forma como o conto é narrado intensifica esse contraste: nos momentos em que Queridinha está com alguém que ama, os fatos são narrados num ritmo mais acelerado, alegre, e, quando a personagem está só, a narrativa torna-se lenta, intensa, cada sentimento e sensação de Queridinha são descritos minuciosamente. O ritmo narrativo oscila conforme o ânimo e a inação da personagem. A atmosfera reflete os sentimentos de Queridinha, a falta de ação ao seu redor é a mesma falta de vontade da personagem. 
A seguir, observaremos dois trechos que marcam bem esse contraste. No primeiro trecho, temos o período mais triste da vida de Queridinha, sozinha, após a morte de todos aqueles que ela amou, inclusive o pai, e o abandono do veterinário:

A casa de Ólenka escureceu, o telhado enferrujou, o celeiro entortou e todo o pátio cobriu-se de urtiga e mato em geral. A própria Ólenka envelheceu, ficou feia. No verão, punha a cadeira na entrada e, como antes, sentia um vazio, monotonia no coração, um gosto de losna. No inverno, ficava sentada à janela, olhando a neve. Às vezes, quando sentia a brisa da primavera, ou quando ouvia o repicar dos sinos da catedral, assoberbavam-na de repente lembranças de seu passado, sentia o coração docemente oprimido, e lágrimas abundantes jorravam-lhe, mas tudo isto durava um instante apenas, depois vinha de novo uma sensação de vazio ${ }^{128}$.

Na sequência, temos um trecho da narrativa logo após a volta do veterinário, que retornava com a esposa e o filho. Ólenka oferece a sua própria casa para que vivam os três, sem cobrar nada por isso.

No dia seguinte, tiveram início a pintura do telhado e a caiação das paredes, enquanto Ólenka andava pelo pátio, a mão no quadril, e dava ordens. Brilhava em seu rosto o sorriso de outrora, toda ela revivera, tornara a viçar, como se houvesse despertado de um sono prolongado. [...] O menino, mal entrou no pátio, pôs-se a correr atrás da gata, e logo se ouviu seu riso prazenteiro $^{129}$.

É a partir desse momento que surge o maior de todos os amores que Queridinha iria sentir: o amor de mãe. A história termina com o menino ao seu lado, o que sugere a longevidade dessa relação, em oposição às outras, que foram relativamente breves.

O contraste entre as duas citações é imenso. Na primeira, temos a tristeza, o amargor, a lentidão, o desânimo e o vazio. Na segunda, aparecem a alegria, o movimento, o ânimo, as palavras usadas são positivas: brilho, sorriso, despertar. São situações opostas, sentimentos opostos.

Portanto, a vida de Queridinha pode ser resumida em dois tipos de momentos: quando ama alguém e quando não ama. O primeiro é a sua segunda alma, ou identidade social, em ação; no segundo, temos a primeira alma, ou identidade subjetiva da personagem, que também pode ser interpretada como uma ausência de alma, o vazio.

\footnotetext{
${ }^{128}$ TCHEKHOV, 2007, p. 309.

${ }^{129}$ Ibidem, p. 310.
} 
Queridinha é a protagonista do conto, mas nunca fala. Todas as vezes em que fala é para repetir o que o outro dizia. Quando era casada com o dono do parque de diversões, tinha grandes considerações a cerca do público cultural, que não gostava de coisas sérias. Quando casou-se com o madeireiro, só pensava em madeira, e começou a desdizer tudo que havia dito anteriormente sobre teatro, afirma que era coisa de quem não tinha o que fazer, demonstrando claramente que as ideias anteriores, assim como as atuais, não eram suas.

Os maridos não se importavam com a personalidade submissa de Queridinha, nem notavam que ela apenas repetia tudo o que diziam, mas o veterinário, que já era casado, não gostou dessa situação. Rapidamente, ele percebe que Queridinha estava se transformando numa espécie de espelho, que refletia tudo aquilo que ele pensava. Não se sentiu confortável com essa condição e partiu, era militar, e o regimento o convocou. Talvez o veterinário preferisse uma mulher que fizesse o papel de amante, por isso Queridinha, que agia como esposa, não o satisfazia.

Retomemos a teoria de Jacobina de que cada ser humano tem duas almas: "uma que olha de dentro para fora, outra que olha de fora dentro...". A primeira alma é interior, equivalente à identidade subjetiva; e a segunda é exterior, como a identidade social. O conto deixa claro que Queridinha é desprovida de uma primeira alma. Não é possível notar nenhum traço de personalidade nela que não seja dos outros. Todas as vezes em que esteve sozinha em sua vida, restou apenas o vazio.

Discutimos anteriormente o lugar da mulher na sociedade russa no período em que o conto de Tchekhov foi escrito (1898), à mulher cabia o papel de companheira e mãe. Tendo em vista essa perspectiva: qual é a identidade social possível para Queridinha?

Não existem possibilidades além do casamento. Trabalhar, estudar, frequentar eventos sociais não está no horizonte da protagonista, o que é justificado pela época em que vivia, não por falta de vontade. Jacobina diz que a segunda alma pode ser um objeto, a temporada de óperas, bailes. Nada disso aparece ligado à vida de Queridinha.

Voltemos ao episódio em que Jacobina se encontra sozinho no sítio da tia Marcolina, o isolamento proposital do personagem faz com que o compreendamos melhor, o objetivo é explicar o que se passou com Jacobina para constatar a existência da segunda alma e entender a sua importância. O mesmo movimento ocorre com Queridinha, que é afastada do convívio com os outros para que a sua personalidade possa ser examinada. 
Quando Queridinha se vê só na sua casa, que parece enorme na descrição do narrador, intensificando a solidão da personagem, o leitor entra em contato com a primeira alma de Ólenka. Quando está sozinha, não há manifestação dessa segunda alma. Não há equilíbrio entre as duas almas, Queridinha só existe em função de suas interações com o mundo, no entanto, não sobra nada além disso. Ela não oferece nada seu nessa relação, não há troca.

Sua inserção em sociedade só se dá quando ela está casada, o movimento em direção ao outro e do outro em sua direção inexiste quando não há essa "alavanca" (figura masculina) para impulsioná-lo. Tanto que os vizinhos notam a mudança no comportamento de Queridinha, que é doce quando casada, e tratam-na com indiferença quando ela está só, porque a sua imagem sentada, sozinha, de preto os repele.

Sozinho no sítio, Jacobina descobre que tem duas existências, uma era o Joãozinho, antes de tornar-se alferes, a outra é o cargo de alferes, que traz a admiração dos outros, esta é a sua segunda alma, representada pela farda. A segunda alma de Queridinha é a função de companheira ou mãe, essa é a sua farda, a máscara que ela precisa para estar em contato com a sociedade.

No entanto, se pensarmos em Jacobina, no que há de autêntico nele, possivelmente chegaremos à conclusão de que ele tem mais em comum com Queridinha do que parece num primeiro momento, pois ambos são definidos pela identidade social.

\subsection{A alma vencedora}

O que Machado de Assis demonstra é que, ainda que a ideia seja de um equilíbrio, em que a identidade individual é uma mistura de interações, com o tempo, a primeira alma tende a se retrair, pela falta de solicitação. $\mathrm{O}$ autor demonstra que a harmonia, que deveria ser mantida, através da interiorização do externo e a exteriorização do interno, não é possível, porque, aos poucos, a única identidade possível para ser aceito é a social.

Para o narrador, se, a princípio, há um embate entre a identidade subjetiva e a social, o que fica claro é que a segunda alma, ou identidade social, vence. O narrador reconhece a impossibilidade de existir naquelas condições uma primeira alma pura, já que ela também é transformada pela segunda.

Jacobina vacila apenas uma vez no sítio da tia. Recém-nomeado alferes, ele pede que ela o chame de Joãozinho, era a primeira alma querendo impedir que a segunda tomasse o seu 
lugar. Mas a farda transformava o olhar dos outros, que passaram a ter respeito por Jacobina. A farda é o meio pelo qual ele passa a ser alferes, é o objeto responsável por lhe doar sua segunda alma. O personagem deixa de ser um Joãozinho qualquer para ser parte do grupo daqueles que integram a Guarda Nacional. É por meio desse objeto simbólico que ele se sente parte de um grupo.

A passagem na qual Jacobina veste a farda no sítio, e passa, a partir desse momento, a usar o uniforme poucas horas por dia, até que a tia retornasse e ele pudesse deixar o sítio e a solidão, é interpretada de maneiras diferentes por alguns críticos. Alfredo Bosi, por exemplo, concorda com Augusto Meyer que a alma interior, a primeira, é eliminada pela alma exterior: “E casos há, não raros, em que a perda da alma exterior implica a da existência inteira ${ }^{130}$." diz o narrador machadiano. No entanto, Paul Dixon, discorda que este seja o relato da derrota da alma interior pela exterior, ele vê o processo como uma cura, momento em que Jacobina atinge o equilíbrio $^{131}$.

Jacobina diz: "Daí em diante, fui outro". E passou a vestir todos os dias a farda por algumas horas, e, assim, pôde esperar pelo retorno da tia, já que não podia abandonar o sítio. Dixon vê neste ato de Jacobina a busca por uma harmonia do "eu", para isso, oferece doses homeopáticas da alma exterior vestindo a farda.

Concordamos com Alfredo Bosi e Augusto Meyer que a segunda alma é a determinante. Não há lugar para que a primeira alma se desenvolva plenamente e, mais, a segunda alma, ou identidade móvel, membrana externa que nos envolve é a que importa, sem ela é difícil, senão impossível, sobreviver.

Essa segunda alma, a identidade social, é de natureza móvel, funciona como uma coleção de máscaras, que foram guardadas ao longo da vida: todo o ser humano tem as suas e pode usá-las de acordo com as solicitações do mundo. Jacobina entendeu como funcionava o jogo das máscaras, Queridinha não pode jogar sozinha, precisa encontrar alguém que seja seu intermediador.

Machado de Assis e Tchekhov estão abordando a vida em sociedade, e a aderência do sujeito a essa segunda alma, que gera a anulação da primeira, a perda de uma essência individual. Ambos os personagens passam por um momento de crise, em que precisam

\footnotetext{
${ }^{130}$ ASSIS, 2011, p. 210.

${ }^{131}$ DIXON, Paul. Os contos de Machado de Assis: mais do que sonha a Filosofia. Porto Alegre: Movimento, 1992.
} 
encarar a si mesmos sem o apoio da segunda alma, sem o outro para dizer quem eles são. Ao final, os dois superam o momento de crise e retomam seus papéis sociais, já que não conseguem se identificar fora deles.

\subsection{A farda simbólica}

A farda real de Jacobina é também simbólica, funciona como alegoria da segunda alma, da identidade móvel, na qual o homem nunca se mostrará confortável. Tchekhov viu na alma feminina uma capacidade maior de adaptação, talvez por isso tenha criado uma personagem feminina para demonstrar a importância do papel social, que é diferente no caso das mulheres, mas que tem o mesmo peso que tem para o homem.

Quase todos os heróis (anti-heróis) modernos são apresentados por meio de uma máscara, alegoria da segunda alma machadiana, a roupa. Não uma simples roupa, mas alguma que denote a origem daquele que a porta. No entanto, como ajuda a compor a identidade social, servindo de veículo, ou sendo ela mesma a representação dessa segunda alma, a roupa é uma espécie de camuflagem e, sendo assim, pode ser uma farsa. No jogo das aparências, uma roupa pode dizer muito sobre aquele que a usa, e, com alguma frequência, o que diz não é verdade.

Desde os primórdios da História, a roupa identifica aquele que a veste. No mundo civilizado, a vestimenta tem uma função muito mais social do que protetora. Até a Idade Média a divisão era ainda mais clara, nobres e camponeses poderiam ser reconhecidos em qualquer lugar por seus trajes. Mas foi com o crescimento da burguesia e após a Revolução Industrial que a roupa tornou-se uma peça-chave para aceitação social ${ }^{132}$.

A roupa é uma espécie de armadura moderna, que protege aquele que a usa do mundo, e o localiza socialmente, caso de Jacobina.

Ora, Jacobina somos nós. Botamos a farda e representamos uma paródia do nosso eu autêntico - não na vida social apenas, na vida profunda do espírito, que anda quase sempre fardado. O imperativo instinto vital se encarrega de fardar o espírito para que ele não se veja no espelho tal como é na verdade. Só existem as almas exteriores, bovarizadas, mascaradas, e para elas, que só navegam na sabedoria da superfície, é melhor não sondar a profundidade terrível do homem. Quem tira a farda, quem tenta ver o que há além da fantasmagoria organizada em seu proveito pela inconsciência

\footnotetext{
${ }^{132}$ CALANCA, Daniela. História Social da Moda. São Paulo: Editora Senac, 2008.
} 
vital, sente a vertigem de si mesmo e de tudo, acaba falando sozinho diante do espelho, como o alferes Jacobina ${ }^{133}$.

Quando as narrativas se aproximaram mais do indivíduo, buscando criar personagens cada vez mais próximos de indivíduos reais - em seu meio e, sobretudo, psicologicamente uma das preocupações será descrever a sua aparência, não a natural, mas a imagem do sujeito em seus trajes. Isso porque o invólucro é como o mundo vê o homem, sendo assim, se torna importantíssimo descrever os modos, o penteado, o falar e, principalmente, a vestimenta.

Jacobina só se sente à vontade com a farda, passa a se ver com os mesmos olhos com que o mundo o vê. A farda é a representação do seu cargo e o conto é todo construído em cima dos significados dessa farda para a vida de Jacobina, que apresenta uma teoria que abarca todos nós que viemos depois dele. O uniforme de Jacobina é a sua segunda alma e sua natureza móvel, que permite ao ser humano ir adequando-se ao papel conforme as solicitações do mundo.

O narrador só fala da roupa de Queridinha quando ela fica viúva do segundo marido: "Usava agora vestido negro, com crepes, e renunciou definitivamente ao chapeuzinho e às luvas" $" 134$.

A descrição acima demonstra claramente o desencanto de Queridinha em relação à vida e a sua impossibilidade de participar da sociedade sem um marido ou filho, o que condiz com a sua forma de agir, todas as suas ações são voltadas para o outro, ou seja, quando está só, não há motivação para vestir-se bem. Sozinha, Queridinha é descrita pelo narrador como "feia e magra", e, por isso, as pessoas não falam mais com ela. O que confirma, mais uma vez, a importância da aparência para a vida em sociedade.

O chapéu e a luva são símbolos de elegância, no entanto, ela abre mão dos dois. Ela mantém os crepes por respeito à memória do marido, que ainda ressoa nela. Depois de seis meses, ela se desfaz dos crepes e dá sinais de que começou a relacionar-se com o veterinário.

A farda de Jacobina é mais do que uma simples vestimenta, isso porque é a representação do seu cargo, que é a sua segunda alma. No entanto, o narrador machadiano chama a atenção para um aspecto importante ligado a roupas e adereços em geral, eles são, muitas vezes, a segunda alma de um indivíduo.

\footnotetext{
${ }^{133}$ MEYER, Augusto. Machado de Assis (1935-1958). Rio de Janeiro: José Olympio, 2008.

${ }^{134}$ TCHEKHOV, 2006, p. 306.
} 
Machado de Assis reforça a ideia do poder quase sobrenatural que pode ter um objeto na sociedade capitalista. Karl Marx (1818-1883) chamou esse fenômeno de fetichismo de mercadoria, em que um produto exerce um poder sobrenatural sobre o seu possuidor. Não se trata de valor real, nem da importância de sua finalidade, mas de satisfazer o "eu". Possuir o objeto significa fazer parte de um grupo, adquirir uma nova identidade, que, ao mesmo tempo que diferencia o sujeito, o torna igual a outros indivíduos, que também são definidos por aquele objeto.

A desvinculação do trabalho empregado para produzir o objeto é um dos maiores problemas apontados por Marx, pois, uma vez que a mercadoria foi manufaturada e está pronta, ela parece ganhar vida e, então, não importa mais como ela foi feita, quanto demorou e qual sua utilidade.

Nesse sentido, o objeto pode ser uma segunda alma, como diz Machado de Assis, pois é como se ele tivesse o poder de transmitir vida àquele que o possui e não o contrário.

\footnotetext{
A alma exterior pode ser um espírito, um fluido, um homem, muitos homens, um objeto, uma operação. Há casos, por exemplo, em que um simples botão de camisa é a alma exterior de uma pessoa; - e assim também a polca, o voltarete, um livro, uma máquina, um par de botas, uma cavatina, um tambor, etc. Está claro que o ofício dessa segunda alma é transmitir a vida, como a primeira; as duas completam o homem, que é, metafisicamente falando, uma laranja ${ }^{135}$.
}

A segunda alma de Jacobina, após a sua nomeação, passa a ser a sua farda, é ela que transforma o olhar dos outros em relação a ele e passará a modificar o seu próprio olhar com relação a si mesmo. A farda de Queridinha são suas relações. Os dois processos são simbólicos.

É como se a personalidade (alma) da pessoa ao lado fosse transferida para Queridinha por meio do processo biológico denominado difusão simples, em que ocorre a passagem de partículas de uma região com maior concentração para uma com menor, até atingirem o equilíbrio. Quando o doador de alma morria, e ela encontrava-se sozinha, ficava sentada, olhando para o infinito, sem ter com o que se preocupar, sem razão para viver.

\subsection{O fantástico e os sonhos}

${ }^{135}$ ASSIS, 2011, p. 210. 
Uma outra similaridade entre os personagens diz respeito à atmosfera criada no momento em que eles se veem isolados. Existe algo de sinistro quando Jacobina não se vê no espelho e também quando Queridinha fica sozinha em sua casa. Ela tinha ficado feia, as pessoas na rua não a olhavam mais. Em sua casa de telhado enferrujado, cercada por um matagal, Queridinha sentava-se sozinha e ficava olhando o pátio vazio, tinha gosto de losna na boca e sua gatinha preta a cercava. Além disso, a própria imagem do ser cindido, que os dois contos trabalha é um tanto fantasmagórica, e aparece com alguma frequência na literatura fantástica, nas obras de Edgar Allan Poe, Dostoiévski, Goethe etc.

Quando Jacobina está sozinho no sítio se descreve como incapaz de realizar alguns movimentos, não sente seus músculos, como se estivesse atrofiado; Queridinha não sente vontade viver, "não pensava em nada, não desejava nada". O aspecto de Ólenka se refletia em sua casa e nas pessoas, que evitavam olhá-la. Os dois personagens passam a agir como autômatos quando estão sozinhos. Não porque deixem de ser humanos, mas porque lhes falta a alma que anima o corpo, a exterior. Jacobina diz que "era como um defunto andando, um sonâmbulo, um boneco mecânico". O mesmo se passa com Ólenka. Parece que ambos estão aí muito próximos da morte.

O conto de Machado de Assis realmente possui elementos que poderiam ser classificados como fantásticos, principalmente a famosa cena do espelho, em que Jacobina não consegue ver-se refletido: “Olhei e recuei. O próprio vidro parecia conjurado com o resto do universo; não me estampou a figura nítida e inteira, mas vaga, esfumada, difusa, sombra de sombra" 136 .

Então o narrador chama o leitor e a si mesmo, de volta ao mundo real: "A realidade das leis físicas não permite negar que o espelho reproduziu-me textualmente, com os mesmos contornos e feições; assim devia ter sido. Mas tal não foi a minha sensação" ${ }^{137}$. De acordo com a clássica definição de Tzvetan Todorov, o fantástico dura apenas o tempo de uma hesitação, que é comum ao leitor e à personagem, ambos devem decidir se o elemento narrado pertence à realidade ou não ${ }^{138}$. O que caracteriza o fantástico então é apenas essa hesitação, o que ocorre com Jacobina, que desconfia estar vivendo uma experiência sobrenatural. Outro estudioso do gênero, Remo Ceserani, diz que o fantástico se configura "pela passagem de

\footnotetext{
${ }^{136}$ ASSIS, 2011, p. 219.

${ }^{137}$ Ibidem.

${ }^{138}$ TODOROV, Tzvetan. Introdução à literatura fantástica. Trad. Maria Clara Correa Castello. São Paulo: Perspectiva.
} 
limite, por exemplo, da dimensão da realidade para a do sonho, do pesadelo, ou da loucura ${ }^{139,}$.

Não são raras as vezes em que Machado de Assis e Tchekhov, escritores essencialmente ligados à realidade, sobretudo Tchekhov, utilizarão um artifício clássico para introduzir o fantástico em suas obras: a criação de um espaço onírico. É por meio dos sonhos que os personagens podem conseguir realizações que são impossíveis dentro de suas histórias pessoais.

A introdução dos sonhos nos dois contos também fortalece a dualidade das duas narrativas, pois amplia o espectro das personagens, aprofundando-as. O sonho é o lugar onde todas as pessoas, reais e fictícias, podem ser outras, é um espaço de fuga, atemporal, nele, a vida real está suspensa e uma outra vida torna-se possível.

Machado de Assis usa esse recurso em muitos contos, como "Uns braços", "A missa do galo", "A chinela turca" entre outros. Tchekhov também utiliza o sonho como uma maneira de fuga da personagem, o único lugar onde é possível ser livre ou ter uma realidade diferente, caso do conto "Olhos mortos de sono" (Сnать хочется).

É importante pontuar que os dois contos foram escritos antes da publicação de $A$ interpretação dos sonhos, de Freud, em 1900. Portanto, na época em que Tchekhov e Machado de Assis os escreveram, ainda não estava claro o funcionamento do inconsciente e o importante papel dos sonhos para a sua compreensão.

Desde a Antiguidade Clássica, os povos tentam interpretar os sonhos. Os gregos acreditavam que os sonhos eram dádivas ofertadas por Prometeu, que, dessa forma, concedeu aos homens alimento para a alma e para o corpo. Os sonhos eram interpretados como sendo reveladores do futuro, seu teor era profético. Algumas culturas acreditam, ainda hoje, no poder dos sonhos de anunciar o porvir. Os gregos acreditavam ainda que existiam sonhos "verdadeiros", nos quais se deveria acreditar, e "falsos"140.

Os sonhos também aparecem em muitos textos bíblicos com uma função profética, há exemplos no Novo e no Velho Testamento. No Novo Testamento, São José é avisado pelo anjo Gabriel de que sua esposa, Maria, espera uma criança que é filha de Deus; é também em

\footnotetext{
${ }^{139}$ CESERANI, Remo. O fantástico. Trad. Nilton Cezar Tridapalli. Curitiba: Ed. UFPR, 2006.

140 KATZ, Michael R. Dreams and the unconscious in nineteenth-century russian fiction. New England: University Press of New England, 1984, pp. 1-16.
} 
sonho que José é alertado de que deve fugir com Jesus, o quanto antes, para o Egito, pois o rei Herodes, temendo perder o trono, havia mandado matar todos os recém-nascidos da vila de Belém.

O sonho era então uma espécie de canal pelo qual os homens recebiam as mensagens de Deus, que, dessa forma, ajudava a livrá-los das desgraças. Os sonhos bíblicos também se dividiam em dois: os verdadeiros, de inspiração divina, vindos de Deus ou dos anjos; e os falsos, de inspiração demoníaca, que levariam os homens ao pecado. Além disso, antes do grande desenvolvimento da ciência, os sonhos eram interpretados como uma explicação para aquilo que o homem ainda não era capaz de explicar de maneira racional.

No final do século XVII, surgiu um movimento de reação contra o excesso ao racionalismo proposto pelo Iluminismo. Houve um crescimento do interesse pelo sobrenatural e pelo inconsciente, estudiosos queriam descobrir técnicas para ter experiências transcendentais: hipnose e sessões espíritas tornaram-se moda na alta sociedade.

O poeta seria aquele que tinha acesso à alma e que estava assim em contato com alguma realidade cósmica. Poetas e prosadores começaram a utilizar os sonhos como uma técnica literária para alcançar uma variedade de efeitos estéticos. Essa corrente, a princípio proposta por teóricos, inspiraria o movimento Romântico. Pertenciam ao grupo que fazia experimentos com sonhos os autores E. T. A. Hoffmann, Charles Nodier, Gérard de Nerval, entre outros.

Ao definir seu próprio papel na história do movimento psicanalítico, Sigmund Freud reconheceu a importância dos poetas e filósofos, que já lidavam com certa noção de inconsciente. A Psicanálise, além de trazer uma formulação original ao conceito de inconsciente, desenvolveu um método científico para estudá-lo.

O sonho, segundo a psicanálise, é dividido em um conteúdo manifesto e um conteúdo latente.

Pode-se entender 'conteúdo latente' num sentido amplo, como conjunto daquilo que a análise vai sucessivamente revelando (associações do analisando, interpretações do analista); o conteúdo latente de um sonho seria então constituído por restos diurnos, recordações da infância, impressões corporais, alusões à situação transferencial, etc ${ }^{141}$.

${ }^{141}$ LAPLANCHE, J; PONTALIS, J. Dicionário de Psicanálise. São Paulo: Martins Fontes, 2001, p. 98. 
"O conteúdo manifesto designa o sonho antes de ser submetido à investigação analítica, tal como aparece ao sonhante que o relata. ${ }^{142 "}$ Enquanto, “o conteúdo latente é um conjunto de significações a que chega a análise de uma produção do inconsciente, particularmente do sonho" "143. A elaboração onírica é a passagem do conteúdo latente para o manifesto. Os sonhos são então o caminho para o conhecimento do inconsciente. O método psicanalítico trabalha com as associações daquele que sonhou para chegar ao conteúdo latente.

Os sonhos literários, segundo Freud, devem ser interpretados não psicanaliticamente, mas simbolicamente, alegoricamente, substituindo o conteúdo do sonho por um que seja inteligível e análogo. Os sonhos inventados por poetas têm por objetivo uma interpretação simbólica, como produto da inspiração do poeta, trata-se de um simulacro, que se parece com os sonhos de pessoas reais.

Há sonhos ficcionais que podem ser interpretados psicanaliticamente, por serem exatos assemelham-se muito ao de pessoas reais. Freud acreditava então que sonhos bem construídos podem ser interpretados através do seu método, produzindo bons resultados. Freud utilizou textos literários para demonstrar suas hipóteses sobre o inconsciente. Ele chegou a interpretar o romance Gradiva (1903) de Wilhelm Jensen, tratando suas personagens como reais, no estudo Delírios e sonhos na Gradiva de Jensen.

Para Freud, o sonho é a realização dos desejos, e, no texto literário, ele aparece muitas vezes como continuação do pensamento dos personagens ${ }^{144}$. Isso porque não são seres reais, mas a imaginação dos autores tentando conceber com o que sonhariam seus personagens, tornando-os, dessa forma, mais humanos. Sendo assim, o sonho dentro da ficção ajuda a constituir um mecanismo de fuga da realidade, o que pode configurar um aspecto fantástico, é também representação da cultura, pode conter uma previsão, ou um aviso.

Os sonhos na literatura também podem tratar de fenômenos que de outra maneira não se realizariam, são acontecimentos incomuns, por isso sua ligação com o fantástico. Há também aquelas narrativas em que os personagens não têm certeza se algum evento de fato aconteceu ou se foi apenas um sonho. O acontecimento é descrito de forma que o leitor também fique na dúvida, caso do conto "Uns braços" de Machado de Assis.

\footnotetext{
142 Ibidem.

143 Ibidem, p. 99.

144 KATZ, 1984.
} 
Seguindo a lógica da estrutura dupla sobre a qual "O Espelho" e "Queridinha" são construídos, a certa altura, os personagens sonham. Através do sonho têm, não apenas a alma dividida em duas partes, mas também a existência, já que o sonho oferece a possibilidade de transcender.

O sono dava-me alívio, não pela razão comum de ser irmão da morte, mas por outra. Acho que posso explicar assim esse fenômeno: o sono, eliminando a necessidade uma alma exterior, deixava atuar a alma interior. Nos sonhos, fardava-me, orgulhosamente, no meio da família e dos amigos, que me elogiavam o garbo, que me chamava alferes; vinha um amigo de nossa casa, e prometia-me o posto de tenente, outro o de capitão ou major; e tudo isso fazia-me viver $^{145}$.

Jacobina, no sítio da tia Marcolina, achava no sonho uma fuga para a sua solidão. O sonho deveria proporcionar liberdade, livrar o ser humano finalmente do olhar do outro, permitir que ele entrasse em contato com a sua alma interior. No entanto, Jacobina sonha que está fardado e que, por isso, as pessoas o admiram, ou seja, o seu sonho é continuação daquilo que vivia quando acordado. A alma interior estava dominada pela alma exterior e dormir representava um alívio porque durante o sono, não estava mais sozinho, mas em companhia de sua farda e da admiração dos outros.

Segundo Freud, os sonhos na literatura são utilizados simbolicamente, seriam um mecanismo pelo qual o autor transmitiria uma mensagem, que não deveria ser interpretada psicanaliticamente, mas sim como uma alegoria. Sonhar com a farda demonstra a vitória da alma exterior, até mesmo num espaço livre do desejo de agradar, ela é quem se sobressai. $\mathrm{O}$ sonho é uma maneira de fazer viver de novo Jacobina que se sentia quase morto sem o olhar de ninguém no sítio.

Seguindo a proposta de Freud, de interpretar o sonho literário como uma alegoria, o sonho de Jacobina contém muitos elementos presentes no próprio conto de forma condensada, além de demonstrar que a liberdade não é possível nem em sonho. Quando acordado, Jacobina tem sua vida delimitada pelo olhar do outro, quando está dormindo, sonha com o outro absoluto, a sociedade e suas estruturas, às quais ele está preso.

Queridinha também sonha com os acontecimentos ligados a sua segunda alma, quando era casada com o comerciante de madeiras,

${ }^{145}$ TCHEKHOV, 2006, p. 217. 
Queridinha sonhava com montanhas de vigas e pranchas com filas infindáveis de carroças, que levavam a madeira para algum lugar distante, fora da cidade. Sonhava ainda com todo o regimento de tábuas, de um palmo por doze archines, que se lançava ao ataque contra o depósito de madeira, via as vigas, pranchas e postes chocarem-se, ressoando estrepitosamente, qual madeira seca. Toda aquela madeira caía e tornava a erguer-se, empilhando-se os objetos uns sobre os outros ${ }^{146}$.

No entanto, quando Queridinha está sozinha, após a partida do veterinário, ela: “Olhava com indiferença para o pátio vazio de sua casa, não pensava em nada, não desejava nada, e depois, quando chegava a noite, ia dormir e via em sonho o pátio vazio. ${ }^{147,}$

Para Jacobina, sonhar é um alívio, porque ele consegue entrar em contato com sua alma exterior. No sonho, ele está acompanhado daqueles que o bajulam. Já Queridinha, sem um marido, encontra-se sozinha, os sonhos dela, considerando as interpretações do sonho em ficção, são apenas uma continuação da sua vida. Os sonhos de Queridinha não representam uma fuga possível, não são a realização de um desejo latente. Os sonhos dos dois refletem a segunda alma, não a primeira.

Os sonhos de Queridinha apenas confirmam a sua incapacidade de viver sem alguém para amar. Os desejos sobre o futuro só fazem parte do seu universo onírico quando descobre um novo amor, nunca antes havia sonhado com o futuro, mas, após conhecer Sasha, ela deseja uma vida melhor para ele. Ao contrário de Jacobina, Queridinha nunca desejou nada para si, era tudo para o outro e, em seu sonho final, sonha com o futuro do menino. "Depois, deitando-se, sonha com o futuro distante e enevoado, em que Sacha, tendo terminado os estudos, será médico ou engenheiro, terá sua própria casa, grande, cavalos, carruagens, vai casar-se e criará filhos..."148

O procedimento dos dois autores é bastante semelhante, utilizam os sonhos como forma de revelar as identidades de seus personagens. Talvez, o espaço do sonho fosse o lugar onde a primeira alma viria à tona, em que os personagens demonstrariam o que realmente são: Jacobina sem a farda de alferes e Queridinha sem os maridos. No entanto, Jacobina sonha com aquilo que ele deseja - a fuga do sítio, a ascensão na carreira militar -, ou seja, seus sonhos fazem reviver a segunda alma e não a primeira. Os sonhos de Queridinha também retrataram as experiências da segunda alma.

\footnotetext{
${ }^{146}$ TCHEKHOV, 2006, p. 305.

147 Ibidem, p. 308.

148 Ibidem, p. 313.
} 


\section{Considerações Finais}

Passado mais de um século desde a publicação dos textos com os quais trabalhamos aqui, definimos as questões dos personagens como problemas relacionados à formação da identidade. É um tratamento contemporâneo dado ao tema, que hoje é amplamente discutido.

Machado de Assis e Tchekhov perceberam cedo a dificuldade que os seres humanos enfrentavam para cumprir seus papéis sociais e se adequarem às solicitações do mundo. A teoria da alma cindida surge na obra de Machado de Assis em 1882, e será uma das marcas da sua segunda fase como escritor. A questão aparece na obra de Tchekhov mais tarde, na década de 1890.

O objetivo principal desta dissertação foi analisar o processo de formação da identidade dos protagonistas das obras escolhidas e compará-los, tendo em vista o contexto histórico e social da Rússia e do Brasil no final do século XIX.

"O Alienista" e "Enfermaria $n^{\circ}$ 6" apresentam temas que eram importantes para a sociedade naquele momento. A loucura aparece como protagonista dessas duas narrativas. Historicamente, quando o louco passa a ser considerado um doente, o tratamento muda, os hospícios são, sem dúvida, melhores do que os antigos asilos onde eles eram internados, no entanto, surgem novas questões, que vão além do tratamento oferecido.

Qual é o lugar do doente mental? Não havia lugar para o desvio de padrão na nova configuração da sociedade urbana moderna, tanto quanto não havia anteriormente, no entanto, agora, é preciso criar um discurso coerente para justificar as ações que devem ser ratificadas pelas pessoas, elas devem concordar com as ações do médico, assim surgem os hospícios. Isso porque, a partir das grandes descobertas científicas do século XIX, é preciso demonstrar cientificamente as razões que levam as autoridades a tomarem algumas decisões e não outras.

O discurso médico tem força de verdade e o seu poder passa a ser exercido quase irrestritamente, como fica claro nas ações de Simão Bacamarte. No entanto, esse processo não é unilateral, a sociedade também anseia pela exclusão do louco, o que faz com que ela valide o discurso científico, o que é mais evidente na "Enfermaria n ${ }^{\circ}$ ". 
Machado de Assis, em "O Alienista", e Tchekhov, na "Enfermaria n” 6", demonstram como o processo descrito acima acontece diante dos moradores de duas pequenas cidades, que são representações de lugares reais, no caso de Itaguaí, muito mais próxima do Rio de Janeiro, então capital do país; e, na novela de Tchekhov, a cidadezinha poderia ser qualquer pequena cidade da Rússia daquele período.

Nesses textos, temos dois protagonistas com um importante papel social: alienista ou psiquiatra. Esse profissional é aquele que se tornou responsável pelo destino de muitos homens, doentes de verdade ou apenas abandonados pela sociedade. Coube ao psiquiatra, no início da implantação da psiquiatria, decidir o rumo de muitas vidas, era uma decisão importante, que deveria ser tomada com rapidez e que não poderia ser revogada.

Além do poder já bastante ligado à figura do médico, o psiquiatra era um instrumento de contenção social ainda mais importante, funcionando como uma espécie de fiscal da sanidade. Bastava qualquer traço de "anormalidade" e o sujeito era encarcerado. "O Alienista" e a "Enfermaria $n^{\circ}$ 6" mostram como essa decisão era muitas vezes tomada baseada em alicerces duvidosos.

Dessa forma, os sujeitos são acusados, presos e julgados sem entenderem bem o que se passou para que isso ocorresse. A justificativa existe sempre, e ela está embasada no discurso científico e/ou jurídico. O julgamento arbitrário foi um dos grandes temas da primeira metade do século $\mathrm{XX}^{149}$, o que demonstra a percepção de Machado de Assis e Tchekhov, que foram precursores na denúncia de uma estrutura burocrática que prende os indivíduos em suas redes até que eles se vejam perdidos em processos que não entendem.

Assim, o sujeito que, na Idade Média, tinha sua vida norteada pela religião e pela ideia de um Deus onipotente, princípio e razão de todas as coisas, passa a ver-se como indivíduo livre e soberano, reconhecido como centro porque pensa, e é então dono da sua vida. Seria, dessa forma, em teoria, capaz de controlar os acontecimentos que o rodeiam. Essa visão logo vê-se frustrada com o surgimento do sujeito social, isto é, aquele que vive em meio a estruturas burocráticas criadas para dar conta do aumento da população. Nesse momento, os indivíduos passam a ser aprisionados novamente, mas agora tanto o carrasco quanto a prisão são diferentes, bem mais difíceis de reconhecer.

149 O Processo de Kafka, O Estrangeiro e O mito de Sísifo de Albert Camus são exemplos de livros que tratam do tema no século XX. 
"O Espelho" e "Queridinha" parecem, a princípio, contos tematicamente diferentes, afinal um trata da história de um homem fluminense de meia-idade, enquanto o outro trata da vida de uma mulher entre 30 e 40 anos, cujos destinos têm pouco ou nada em comum. Contudo, são textos que problematizam o mesmo fenômeno: como os sujeitos do século XIX estavam aprendendo a conviver com a ideia de que as suas vidas estariam sempre dividas em dois.

Há uma vida que se passa internamente, aquela que carrega os desejos e inseguranças do ser humano, e uma outra que deve imitar a aparência dominante, portanto, é aquilo que os outros veem. A ideia da máscara social é antiga, mas um elemento novo passa a existir, ligado à modernidade, que é a necessidade de desenvolver uma identidade subjetiva, um "eu", que influencia e é influenciado pelo “outro”. O que causa um embate entre o interno e o externo.

Jacobina descobriu cedo que deveria adaptar-se ao meio, e os eventos narrados em " $\mathrm{O}$ Espelho" mostram como foi esse aprendizado. Queridinha descobre seu lugar na sociedade desenvolvendo o papel de esposa. Queridinha e Jacobina são mostrados nos momentos de suas vidas em que a identidade social os solicita. O momento da descoberta da atuação dessa segunda alma é doloroso.

O que há em comum entre Bacamarte, Ráguin, Gromov, Jacobina e Queridinha é o fato de serem retratos de sujeitos do século XIX. Todos eles passam pelo processo de construção de suas identidades durante as narrativas que analisamos aqui. Simão Bacamarte e Ráguin são apresentados já exercendo a importante função de médico, são, portanto, agentes sociais responsáveis por manter a ordem, separando os doentes dos saudáveis. Essa função os coloca acima dos cidadãos comuns, pois são, em certa medida, responsáveis pela população. Levam, em parte por isso, uma vida de isolamento, em que suas relações com os outros são superficiais.

Ser médico é, a princípio, a segunda alma de Ráguin e Bacamarte, é assim que se colocam em contato com os outros. No entanto, não há interação nas relações gerais dos dois, o que muda quando Ráguin entra em contato Gromov, no qual ele se reconhece. Então, a segunda alma de Ráguin, assim como será também a de Bacamarte, deixa de ser o exercício da Medicina e passa a ser a loucura, por decisão daqueles que o observam, porque, ao se aproximar de Gromov, ele se coloca no mesmo plano do doente, o que não era possível aos olhos daquela sociedade. Ráguin e Bacamarte terminam loucos, internados nas instituições 
pelas quais eram responsáveis, passando a ocupar o mesmo lugar daqueles que estavam internados por decisão deles.

Para encerrar, ao final de "A Dama do Cachorrinho", o personagem Gurov, que é casado e tem um caso amoroso, que o faz sofrer terrivelmente com a impossibilidade de abrir mão de sua vida social em nome de sua vida pessoal, em um pensamento, resume bem o que era um dos dilemas mais importantes para o indíviduo moderno e talvez ainda seja para os homens de hoje.

Tinha duas vidas: uma, aparente, que viam e conheciam todos os que o que queriam, repassada de verdade e de mentira convencionais, completamente semelhante às vidas de seus conhecidos e amigos, e outra que decorria em segredo. [...] Cada existência individual baseia-se no mistério e talvez seja, em parte, esta a razão por que o homem culto se afana tão nervosamente para ver respeitado o mistério individual ${ }^{150}$.

${ }^{150}$ TCHEKHOV, 2006, p. 331. 


\section{Referências}

ABERCROMBIE, N., HILL, S. e TURNER, B. (orgs.) Diccionario de Sociologia. Madrid: Ediciones Cátedra, 1992.

AGAMBEN, Giorgio. O que é contemporâneo? e outros ensaios. Chapecó: Argos, 2010.

ANGELIDES, Sophia. A. P. Tchekhov: Cartas para uma Poética. São Paulo: EDUSP, 1995. . Carta e Literatura (A Correspondência entre Tchekhov e Górki). São Paulo: EDUSP, 2001.

ANTUNES, Eleonora Haddad; e outros. Psiquiatria, Loucura e Arte: Fragmentos da História Brasileira. São Paulo: Edusp, 2002.

ASSIS, Machado. Obra completa. Rio de Janeiro: Nova Aguilar, 2000.

Papéis Avulsos. São Paulo: Penguin \& Companhia das Letras, 2011. . 50 Contos de Machado de Assis. Org. John Gledson. São Paulo: Companhia das Letras, 2007.

. Páginas Recolhidas/Relíquia de Casa Velha; edição preparada por Marta de Senna. São Paulo: WMF Martins Fontes, 2008.

. Várias Histórias. São Paulo: W. M. Jackson Inc. Editores, 1957.

BENJAMIN, Walter. Magia e Técnica, Arte e Política. São Paulo: Brasiliense, 1996. . A modernidade e os modernos. Rio de Janeiro: Tempo Brasileiro, 1975.

BERMAN, Marshall. Tudo o que é sólido desmancha no ar. São Paulo: Companhia das Letras, 2007.

BÍBLIA SAGRADA. São Paulo: Paulus, 1990.

BILLINGTON, James H. El icono y el hacha. Madrid: Siglo XXI de España Editores, 2011.

BISCHOF, Betina. Um improvável precursor: Tchechov e Kafka. In: Literatura e Sociedade (USP), v. 9, p. 112-123, 2006. 
BLAISE, Pascal. Pensamentos. São Paulo: Martins Fontes, 2005.

BOSI, Alfredo. O enigma do olhar. São Paulo: Martins Fontes, 2007. . História concisa da literatura brasileira. São Paulo: Cultrix, 2006.

BOURDIEU, Pierre. Sociologia. São Paulo: Ática, 1983.

BROCA, Brito. Machado de Assis e a política. SP, Polis/INL, 1983.

CALANCA, Daniela. História Social da Moda. São Paulo: Editora Senac, 2008.

CANDIDO, Antonio. et. al. A personagem de ficção. São Paulo: Perspectiva, 1964 . Esquema de Machado de Assis. In: . Vários escritos. 2. ed. São Paulo: Duas Cidades, 1977.

. Formação da Literatura Brasileira - Momentos Decisivos 1750-1880. 14. ed. Rio de Janeiro: Ouro Sobre Azul, 2013. Recortes. Rio de Janeiro: Ouro Sobre Azul, 2004.

CARPEAUX, Otto Maria. Ensaios Reunidos: 1942-1978. Rio de Janeiro: Topbooks, 2006.

CARVALHAL, Tânia Franco. Literatura Comparada. São Paulo: Ática, 2010. e COUTINHO, Eduardo. Literatura Comparada: Textos fundadores. Rio de Janeiro: Rocco, 2011.

CESERANI, Remo. O fantástico. Trad. Nilton Cezar Tridapalli. Curitiba: Ed. UFPR, 2006.

COMTE, I. Auguste M. F. Xavier. Princípios de filosofia Positiva. São Paulo: Ed. Paulista, 1876.

CORTÁZAR, Julio. "Do conto breve e seus arredores" e "Alguns aspectos do conto". In Valise de Cronópio. São Paulo: Perspectiva, 2011.

COUTO, Mia. Raiz de Orvalho de outros poemas. São Paulo: Leya, 2011.

DEGANI, Francisco. Pirandello "Novellaro": da forma à dissolução. São Paulo: Nova Alexandria/Humanitas, 2009. 
DIXON, Paul. Os contos de Machado de Assis: mais do que sonha a Filosofia. Porto Alegre: Movimento, 1992.

DOSTOIÉVSKI, Fiódor. O Idiota. Trad. Paulo Bezerra. São Paulo: Ed. 34, 2002.

EIKHENBAUM, Boris. In TOLEDO, Dionísio de Oliveira (org.). Teoria da literatura: formalistas russos. Porto Alegre: Ed. Globo, 1971.

FAORO, Raymundo. Machado de Assis: A pirâmide e o trapézio. 2 ed. São Paulo: Companhia Editora Nacional (Brasiliana, volume 356), 1976.

FIGES, Orlando. A tragédia de um povo: A Revolução Russa 1891-1924. São Paulo: Record, 1999.

FOUCAULT, Michel. A ordem do discurso. Trad. Laura Fraga de Almeida Sampaio. São Paulo: Edições Loyola, 1996. . História da Loucura. São Paulo: Perspectiva, 1978. . Microfísica do poder. Petrópolis: Vozes, 1995. . "O sujeito e o poder.” In: DREYFUS, H.; RABINOW, P. Michel Foucault, uma trajetória filosófica. Rio de Janeiro: Forense Universitária, 1995, p. 231-49. . Vigiar e Punir. Petrópolis: Vozes, 1987.

FREUD, Sigmund. Delírios e sonhos na Gradiva de Jensen. Rio de Janeiro: Imago, 1976.

GLEDSON, John. Machado de Assis: ficção e história. Rio de Janeiro: Paz e Terra, 1986. . Por um novo Machado de Assis. São Paulo: Companhia das Letras, 2006.

GOMES, Eugênio. Machado de Assis: Influências Inglesas. Rio de Janeiro: Pallas; Brasília: INL, 1976.

GOMIDE, Bruno Barretto. (Organização, apresentação e notas) Antologia do pensamento crítico russo (1802-1901); trad. Cecília Rosas e outros. São Paulo: Ed. 34, 2013.

. (Organização, apresentação e notas). Nova Antologia do Conto Russo (17921998); trad. Arlete Cavaliere e outros. São Paulo: Ed. 34, 2011. 
Edusp, 2012.

Da estepe à caatinga: O Romance Russo no Brasil (1887-1936). São Paulo:

GOTLIB, Nadia Battella. Teoria do Conto. São Paulo: Ática, 1991.

GROJNOWSKI, Daniel. Lire la nouvelle. Paris: Nathan, 2000.

HALL, Stuart. A identidade cultural na pós-modernidade. Trad. Tomaz Tadeu da Silva e Guacira Lopes Louro. Rio de Janeiro: DP\&A, 2011.

HAUSER, A. História social da arte e da cultura. São Paulo: Martins Fontes, 2003.

HOBSBAWM, Eric J. A era dos impérios 1875-1914. (Trad. Sieni Maria Campos e Yolanda Steidel de Toledo) São Paulo: Paz e Terra, 1998.

JOBIM, José Luís. (Org.) A biblioteca Machado de Assis. Rio de Janeiro: Top Books \& Academia Brasileira de Letras, 2001.

KATÁIEV, V. B. A prosa de Tchekhov: problemas de interpretação (em russo). Moscou: Ed. Escritor Soviético, 1976.

KATZ, Michael R. Dreams and the unconscious in nineteenth-century russian fiction. New England: University Press of New England, 1984.

LACAN, Jacques. "O estádio do espelho como formador da função do eu.” In: Escritos. Rio de Janeiro: Zahar, 1998.

LAFFITTE, Sophie. Tchekhov. (trad. de Hélio Pólvora). Rio de Janeiro: José Olympio, 1993.

LAPlanCHE, J; PONTALIS, J. Dicionário de Psicanálise. São Paulo: Martins Fontes, 2001 .

LIMA, Rodrigo Ferreira de. Um estudo da personagem feminina nos contos de Tchekhov. Dissertação de mestrado apresentada ao Programa de Pós-graduação em Literatura e Cultura Russa do Departamento de Letras Orientais da Faculdade de Filosofia, Letras e Ciências Humanas da Universidade de São Paulo, 2012.

MAGALHÃES JR., Raimundo. A arte do conto. Rio de Janeiro: Bloch, 1972.

MAIAKÓVSKI, Vladimir. "Os dois Tchekhov”. In Schnaiderman, Boris. A Poética de Maiakóvski. São Paulo: Perspectiva, 1985. 
MASSA, Jean-Michel. A juventude de Machado de Assis (1839-1870). Rio de Janeiro, Civilização Brasileira INL, 1971.

MAYA, Alcides. Machado de Assis: algumas notas sobre o "humor". Porto Alegre: Movimento/UFSM, 2007.

MEYER, Augusto. Machado de Assis (1935-1958). Rio de Janeiro: J. Olympio/ABL, 2008. (Organização de Alberto da Costa e Silva)

NABOKOV, Vladimir, Anton Chekhov, in Lectures on Russian Literature. Boston: Mariner Books, 2002.

NASCIMENTO, Rodrigo Alves do. Tchékhov no Brasil: a construção de uma atualidade. Dissertação de mestrado apresentada ao Programa de Pós-graduação em Literatura e Cultura Russa do Departamento de Letras Orientais da Faculdade de Filosofia, Letras e Ciências Humanas da Universidade de São Paulo, 2013.

OLIVEIRA, William V. de. "A fabricação da loucura: contracultura e antipsiquiatria." In: Revista História, Ciência, Saúde-Manguinhos, vol. 18. n. 1. Rio de Janeiro, março de 2011.

PARSONS, Talcott; OLDS, James e BALES, Robert. Family, socialization and Interaction Process. Kentucky: Routlegde, 1999.

PEREIRA, Lúcia Miguel. Machado de Assis: estudo crítico e biográfico. 5. ed. rev. Rio de Janeiro: J. Olympio, 1953.

PERES, Paulo Dal-Ri. O Discurso Psquiátrico e anti-psquiátrico de Tchekhov em sua manifestação literária. Tese de doutoramento apresentada ao Programa de Pós-graduação em Literatura e Cultura Russa do Departamento de Letras Orientais da Faculdade de Filosofia, Letras e Ciências Humanas da Universidade de São Paulo, 1984.

PEZ, Tiaraju Dal Pozzo. "Pequena análise sobre o sujeito em Foucault: a construção de uma ética possível.” In Anais do VII Sepech - Seminário de Pesquisas em Ciências Humanas - da Universidade de Londrina, 2008.

PIZA, Daniel. Machado de Assis: Um gênio brasileiro. São Paulo: Imprensa Oficial do Estado de São Paulo, 2008. 
POE, Edgar Allan. "A Filosofia da Composição" In Poemas e Ensaios. (trad. de Oscar Mendes e Milton Amado). São Paulo: Globo, 1999. 3. ed. revista.

PÓLVORA, Hélio. "Tchekhov: Uma Poética do Conto e do Drama". In: Revista USP, São Paulo (n³0): Junho/Agosto, 1996.

RAYFIELD, Donald. Anton Chekhov - A Life. London: Faber Finds, 2013.

ROSENFELD, Anatol. "A teoria dos gêneros”. In O teatro épico. São Paulo: Perspectiva, 1985.

SCHNAIDERMAN, Boris. "Por falar em conto". O Estado de S. Paulo. Suplemento de $7 / 11 / 1971$.

SCHWARZ, Roberto. Ao vencedor as batatas. São Paulo: Duas Cidades, 2000. . Martinha versus Lucrécia. São Paulo: Companhia das Letras. . Um mestre na periferia do capitalismo: Machado de Assis. São Paulo: Duas Cidades, 1990.

. "Uma crônica de Machado de Assis". In Revista Serrote, n. 4. São Paulo: Instituto Moreira Salles, 2010.

SENNA, Marta de. O olhar oblíquo do Bruxo. Rio de Janeiro: Nova Fronteira, 1998. (Org.). Machado de Assis, cinco contos comentados. Rio de Janeiro: Fundação Casa de Rui Barbosa, 2008.

SILVA, Tomaz Tadeu da. "A produção social da identidade e da diferença." In: SILVA, Tomaz Tadeu (org. e trad.). Identidade e diferença: a perspectiva dos estudos culturais. Petrópolis: Vozes, 2000.

SILVEIRA, Daniela Magalhães da. Fábrica de Contos: Ciência e Literatura em Machado de Assis. Campinas: Ed. Unicamp, 2010.

STALLONI, Yves. Os gêneros literários. Trad. Flávia Nacimento. Rio de Janeiro: Difel, 2001.

SZASZ, Thomas. A fabricação da loucura. Rio de Janeiro: Jorge Zahar, 1983. 
TCHEKHOV, Anton. Pólnoe sobránie sotchinénii i pissem [Obras completas e cartas]. Moscou: Nauka, 1983. (Чехов, Антон. Полное собрание сочинений и писем в 30 томах. Москва: Наука, 1983.)

. A dama do cachorrinho e outros contos. (Trad. Boris Schnaiderman). São Paulo: Editora 34, 2006.

A life in letters. (Trad. Anthony Phillips e Rosamund Bartlett) New York: Penguin Classics, 2004.

. Cartas a Suvórin (1886-1891). Trad. e Org. Aurora Bernardini e Homero Freitas de Andrade. São Paulo: Edusp, 2002.

. Minha Vida. (Trad. Denise Sales). São Paulo: Editora 34, 2011.

. O beijo e outras histórias. (Trad. Boris Schnaiderman). São Paulo: Editora 34, 2007.

. O violino de Rotschild e outros contos. Mairiporã: Veredas, 1991, seleção tradução e notas de Noé Silva.

. O assassinato e outras histórias. (Trad. de Rubens Figueiredo) São Paulo: Cosac \& Naify, 2002,

. Sem trama e sem final: 99 conselhos de escrita. Seleção e prefácio de Piero Brunello. Trad. do italiano e do russo e notas, Homero Freitas de Andrade. São Paulo: Martins Fontes, 2007.

Teresa: revista de literatura brasileira / Programa de Pós-graduação da Área de Literatura Brasileira. Departamento de Letras Clássicas e Vernáculas. Faculdade de Filosofia, Letras e Ciências Humanas. Universidade de São Paulo. São Paulo: Ed. 34: Imprensa Oficial, 2006.

TODOROV, Tzvetan. Introdução à literatura fantástica. Trad. Maria clara Correa Castello. São Paulo: Perspectiva.

VOGÜÉ, E. Melchior de. O romance russo. Trad. Brito Broca. Rio de Janeiro: A Noite, 1950. 
. “Anton Tchekhof”. Revue des Deux Mondes. Jan-Fev 1902, p. 201-216.

WOOLF, Virgínia. The Common Reader. San Diego: Havest Book, 1984.

Sites

theguardian.com, Friday 6 May, 2011

http://itaguai.rj.gov.br/pmi/cidade-2/

http://www.psychiatrictimes.com/special-reports/state-psychiatry-russia/page/0/1 
